\title{
Going Global: Transition from Plan to Market in the World Economy
}

by

Padma Desai, Columbia University

January 1997

Discussion Paper Series No. 9697-13

de $9697-13$

pages: 92 


\title{
GOING GLOBAL: \\ TRANSITION FROM PLAN TO MARKET \\ IN THE WORLD ECONOMY*
}

\author{
by \\ Padma Desai \\ Gladys and Roland Harriman Professor of \\ Comparative Economic Systems \\ Columbia University \\ January 1997
}

\begin{abstract}
*This is the introductory chapter in the forthcoming volume of essays based on the research project directed by Padma Desai and financed by the United Nations University/World Institute for Development Economics Research (UNU/WIDER), Helsinki. The project design was developed at a Helsinki conference in the Spring of 1994 and the papers were discussed at a subsequent conference in the Spring of 1995. They have been edited by Padma Desai. The volume will be published by The MIT Press.
\end{abstract}




\section{TABLE OF CONTENTS OF THE VOLUME}

Introduction

Padma Desai

\section{Central and East Europe}

1 The Czech Republic

Josef C. Brada, Arizona State University

and A. M. Kutan, Southern Illinois University

2. Hungary

Andras Blaho, United Nations, and Peter Gal, Budapest University of Economics

3. East Germany

Jurgen von Hagen, University of Bonn and Indiana University

4. Poland

Stanislaw Wellisz, Columbia University

\section{The North European Economies}

5. The Baltic States: Estonia, Latvia and Lithuania

Kalev Kukk, Member, Estonian Parliament and Board of Easti Pank

6. Finland

Urpo Kivikari, Turku School of Business and Economic Administration

\section{The Post-Soviet States}

\section{Russia}

Padma Desai, Columbia University

8. Kazakhstan

Heiner Flassbeck, Lutz Hoffmann, German Institute for Economic Research, and Ludger Lindlar, University of Groningen

9. Uzbekistan

Michael Connolly, University of Miami

\section{East, Southeast and South Asia}

\section{China}

Richard S. Eckaus, Massachusetts Institute of Technology

11. Vietnam

David Dollar, World Bank, and Borje Ljunggren, Ambassador of Sweden to Vietnam

12. India

Manmohan Agarwal, Jawaharlal Nehru University 


\section{TABLE OF CONTENTS}

The Criteria of Country Selection

Defining "High-," "Medium-," and "Low-" Speed Reformers

Assigning Countries to the Three Groups

Common Features of the Transition by the End of 1995

Prices and Inflation Control

Exchange Rate Management

Foreign Trade

Growth Rates

Unemployment Rates

$\underline{\text { Reformers at Risk }}$

\section{Going Global: The Indicators}

\section{Going Global: Ranking by Policy Outcomes}

Country Ranking by Exchange Rate Regime in 1995

The Real Economy and the Uneven Progress towards Convertibility by 1995

External "Fragility" Factors and the 1995 Foreign Exchange Regime Rankings

Country Ranking by Trade and DFI Policy Regime in 1995

Ranking by Foreign Trade Regime

Ranking by Receptivity of DFI Environment (by the end of 1995)

Going Global: Ranking by Flows

Country Ranking by Trade Flows in 1995

Country Ranking by DFI Flows in 1993-1995

Comparative Performance: Some Key Results

Reform Speed and the "Fundamentals": Growth. Inflation and Unemployment

Reform Speed and Globalization

Summing Up

Text Tables 1-5

Text Figures 1-5 
Appendix

Notes

References 


\begin{abstract}
This essay analyzes the continuing integration of several transition economies of Europe, the former Soviet Union (FSU) and Asia into the world trading and financial system in the period 199095.

Suitable norms are developed in the essay for comparing and ranking the integration record of the countries and for addressing the critical issue of the transition debate, i.e. whether speedier reform has facilitated their faster entry into the world economy.

Among the countries included for the comparative performance are the Czech Republic, Hungary, and Poland in Central and East Europe; Estonia, Latvia and Lithuania in Northern Europe; Russia, Kazakhstan and Uzbekistan among the post-Soviet states; and China, Vietnam and India in Asia.

Given the small sample, the conclusions are tentative but nevertheless interesting. Reform speed, as defined in the essay, appears to be significantly correlated with the GDP growth rate, with the emergence of a liberalized foreign exchange and trade regime by the end of the period studied, and also with positive globalization outcomes such as increased direct foreign investment flows (measured as their contribution to gross fixed investment when the period examined ends). It also correlates well with declining inflation rate over the period but somewhat poorly with the decline of inflation from its peak to the next year in the "shock therapy" mode.

Speedy reform thus seems desirable, for its general economic results as for globalization. However, this conclusion must be tempered by the fact that speedy reform seems to be associated negatively with the unemployment rate, so that we may well be facing a short-run tradeoff between growth and globalization on the one hand, and unemployment, on the other. In practice, these shortrun tradeoffs could mean that speedy reform may not be politically sustainable.
\end{abstract}




\section{INTRODUCTION}

Padma Desai

These essays analyze the continuing integration of several transition economies of Europe, the former Soviet Union (FSU), and Asia into the world trading and financial system. The authors of the essays on the countries studied in this volume discuss the market-oriented adjustment policies of each with regard to the trade and exchange rate regimes. They also assess the economy's progress in diversifying its trade structure and orienting it toward hard currency markets and in attracting foreign direct investment (FDI). Their analyses span the period 1990-95.

The authors consider the issues of macroeconomic stabilization and price liberalization insofar as they influence the foreign trade and foreign exchange arrangements. Similarly, privatization is introduced into the discussion to the extent that it helps cut back budgetary support of state-owned enterprises (thereby easing the fiscal stress), stimulates foreign trade (by dismantling state trading organizations, for example), and attracts FDI in privatized companies.

Suitable norms need to be adopted, however, for assessing the comparative performances of these transition economies in the initial years of their opening up into the world economy. I develop them in this chapter and thus am able to compare and rank the integration record of these countries and to address the critical issue of the transition debate, that is, whether speedier reform in these economies has facilitated their faster entry into the world economy. ${ }^{1}$

The answer to this question raises analytical issues concerning the assessment of reform speed and the choice of the outcome indicators that might be associated with it. For example, should GDP growth rate be adopted as the sole index of a successful reform strategy? Should a rising 
unemployment rate, which raises formidable challenges for policy makers en route to economic stabilization, be included in the assessment? Since the objective is to assess the globalization of these transitional economies, what indices on the external front should we look for in order to make such an assessment? And how does the presence or absence of successful general reform relate to the success or failure of globalization?

In seeking answers to these and related questions, I rely on the authors' in-depth analyses of the transition strategies adopted by policy makers in the selected countries. The detailed record (which I enlarge and update through mid-1996 in the Appendix) helps me discuss and develop meaningful criteria for assessing the successes and failures of the transition process; for ranking the countries according to these criteria; and finally, for emphasizing the analytical issues that arise when reform speed is correlated with these rankings.

Given the small sample, my conclusions are tentative but nevertheless interesting. Reform speed, as defined below, appears to be significantly correlated with the GDP growth rate, with the emergence of a liberalized foreign exchange and foreign trade regime by the end of the period studied, and with positive globalization outcomes such as increased FDI flows (measured as their contribution to gross fixed investment at the end of the period examined). It also correlates well with declining inflation rate over the period, though somewhat poorly with the decline of inflation from its peak to the next year in the "shock therapy" mode.

Speedy reform thus seems desirable, for its general economic results as for globalization. However, this conclusion must be tempered by the fact that speedy reform seems to be associated negatively with the unemployment rate, so that we may well be facing a short-run trade-off between growth and globalization, on the one hand, and unemployment, on the other. In practice, these 
short-run trade-offs could mean that speedy reform may not be politically sustainable: the electorate may not be willing to put up with the short-term increase in unemployment even though, in the long run, the faster growth would create more jobs. The reformers may then have to choose, for political viability, slower reform strategies. They may well decide that a slower output recovery or expansion in the short run might yield a higher growth rate later by keeping the transition on track, whereas a rapid turnaround, which results in unsustainable unemployment (or income disparities or real wage decline), might be politically destabilizing. ${ }^{2}$

\section{The Criteria of Country Selection}

A few words on the selection of the countries studied in this volume are in order. A qualifying country had to be centrally planned in the past and undergoing a market transition in the present. Thus, the volume includes the Czech Republic, Hungary, the former German Democratic Republic (East Germany hereafter), and Poland in Central and East Europe; Estonia, Latvia, and Lithuania in Northern Europe; Russia, Kazakhstan, and Uzbekistan among the post-Soviet states; and China and Vietnam in Asia. In contrast with the usual focus on the European transition economies or the post-Soviet states or both, it adopts a more variegated sample by including the Asian reforming economies. ${ }^{3}$

Finland, the host country of the research project leading to this volume, was included simply because it constitutes the flip side of the transition economics of socialist countries. While the latter countries have been moving away from socialism, in varying ways and with various results that are examined in this volume, that very transition has had a severe impact on some countries, especially

Finland, a market economy, because of the sudden termination of significant socialist-style trade arrangements with the former Soviet Union. Finland has had to cope with this fallout from the 
dissolution of the Soviet Union in December 1991, an adjustment examined carefully in Chapter 6. Obviously, however, Finland does not qualify for inclusion in the extensive cross-national transition experiences examined in the present chapter and is therefore excluded from that analysis below. ${ }^{4}$

On the other hand, India, though formally not a centrally planned economy (CPE), does qualify. The Indian economy has long been marked by public ownership of much industry and a Kafkaesque network of regulatory controls on private decisions relating to investment, production, and trade. Also, the Indian rupee was not convertible on current or capital account. The economy had, in effect, many of the regime features that the socialist transition economies have wanted to shed. And, like these economies, India began serious reforms in the early 1990s.

A principal objective of reforms in these economies has been to move into the world trading and financial system. In order to accomplish this goal, their policy makers have needed to control inflation under a regime of market prices and private ownership of assets, liberalize their foreign trade arrangements, unify and stabilize their exchange rates, manage them so as to maintain trade competitiveness, and offer attractive incentives to foreign investors.

The country authors analyze in depth the interaction between these objectives aimed at globalization, and the policies adopted to achieve them in the context of the general reform effort and the specific constraints and advantages obtaining in their respective countries. These country policies are summarized in some detail, for ready reference, in tabular form in the Appendix.

Analysis requires, however, that I proceed first with a functional classification of the chosen countries into groups based on the nature and speed of their reforms, so that this in turn can be related to the globalization outcomes, among other things. 


\section{Defining "High-," "Medium-," and "Low-Speed" Reformers}

The countries fall into three groups: the high-, medium-, and low-speed reformers. Speed reflects several dimensions. An early start is one element. Rate of (effective) implementation of initiated reforms is another. Comprehensiveness of the reforms is yet another. The last element is perhaps the most important in practice: a reform package usually includes several components, among them price decontrol, fiscal and monetary tightening to slash inflation, the unification and convertibility (on current account) of the currency, trade liberalization, and the undertaking of privatization.

Given the different dimensions that can be combined in several ways, I have chosen to classify countries into three groups below by using qualifying characteristics that draw on the country experiences (that have been analyzed in the volume) and thus make the comparative analysis more meaningful.

First, it therefore makes sense to characterize as high-speed reformers those countries that opt for a comprehensive policy package, introduce it early, and maintain it in place. However, it is sometimes difficult to decide whether a country belongs to the high-speed category if the different elements of the reform package are pursued at strikingly different speeds. For example, Vietnam has moved swiftly and effectively on price decontrol, currency unification, and stabilization but has seriously lagged behind on trade liberalization and privatization. Should it be included in the high-speed category? I believe so, in view of the seriousness of the problems where it did implement swift and decisive reforms. This amounts, then, to exercising one's best judgment on the reform process observed, which is inevitable when many dimensions are involved. ${ }^{5}$

Second, the medium-speed reformers, commonly known as gradualists, often start policy 
reform packages on time but are typically slow to implement key elements. I need to emphasize here that the debates in the literature on Russian reform between "shock therapists" such as Jeffrey Sachs and "gradualists" such as myself have been about the speed of reform on one critical dimension: the speed at which stabilization should be undertaken. In early 1992, when Prime Minister Yegor Gaidar announced, and tried to implement shock therapy in the form of a drastic and immediate reduction of the Russian budget deficit from an estimated high, 17 to 21 percent of GDP in 1991, to zero by the first quarter of 1992, he failed because the Supreme Soviet (the parliament) rejected such a drastic program, exactly as gradualists feared. ${ }^{6}$ The view of the shock therapists--that gradualism in attacking high inflation would not work at all and would spell continuing inflationary chaos--has been belied not just by academic analysis such as mine in Desai (1994a, 1994b, 1994c, 1995a, 1995b) but also by the undeniable fact that gradual and firm application of macroeconomic discipline, with the aid of International Monetary Fund (IMF) monitoring, indeed reduced inflation significantly during the Yeltsin-Chernomyrdin-Chubais government of 1994-96. ${ }^{7}$

Thus, given the political constraints faced by a transition economy, it may well be prudent to go easy on certain critical components of a policy package, even though this places the country in the "medium-speed", gradualist category. The Russian case, with the quick reversal of shock therapy upon stabilization, makes for an appropriate illustration. But this slowing of speed on stabilization, while other feasible elements such as privatization, exchange rate unification, and price decontrol were being pushed ahead, is then to be regarded as sensible and "efficient."

These approving words, however, do not apply to the "gradualism" that simply reflects intellectual confusion or bureaucratic inertia or ideological obscurantism, clearly identifiable as such in the early episodes of the "market socialism" reforms in the transition economies. In these cases, 
there were limited nods toward the market mechanism without a true grasp of the market principles. Thus, the limited reforms in Russia under Mikhail Gorbachev suffered from the incoherence that attempts at converting communism to some form of "market socialism," more user-friendly to the old ways of central planning, inevitably implied. ${ }^{8}$

The third category of "low-speed" reformers could have been countries that embraced "market socialism." However, this approach had been generally discredited, and rightly so, fairly early on, and the countries making the transition have generally abandoned the illusion that such an approach makes any sense. Thus, the category of "low-speed" reformers here applies to those countries that have generally delayed starting on their reforms still later in the the period 1990-95 and also happen to be moving slowly on most fronts.

The countries in this volume are assigned immediately below to these three groups, with the reasons for the category choice set forth briefly.

\section{Assigning Countries to the Three Groups}

Poland obviously belongs to the high-speed reformers. Its transition package of January 1990 had the ideal program: the budget deficit was to be reduced sharply, with a view to slashing inflation; almost all prices were freed; the zloty was unified, devalued, and fixed against the dollar; trade restrictions were abolished; and tariffs were either removed or drastically lowered. The Czech Republic, the Baltic states, and Vietnam adopted similar transition packages. Speed also was the essence of East Germany's transition from a socialist to an open market economy: the full economic, monetary, and social union of East Germany with West Germany on July 1, 1990, implied that a slow transformation during which East Germany might have rebuilt itself economically (while retaining its political autonomy and its monetary and fiscal system) was ruled out. The East German 
case was unique, however, because speed involved reunification rather than macroeconomic stabilization per se.

By contrast, post-1990 Hungary and post-Mao China in the medium-speed group adopted a slow agenda. The Hungarian policy makers failed to get a decisive grip on macroeconomic stabilization and on the devaluationary expectations of insiders and outsiders with regard to the Hungarian forint until mid-1995. China's reforms under Deng Xiaoping were deliberately slow. Foreign trade was tightly controlled, import restrictions were in place, dual prices and multiple exchange rates prevailed, and inflation control was shaky.

India also belongs to this group of medium-speed reformers. In July 1991, it was hard put to break away from the legacy of a misdirected, import-substituting, and overregulated economy that had existed for almost four decades. The planners had assigned a dominating role to the state in industry and infrastructure, imposed licensing requirements on private investment, controlled the foreign trade and foreign exchange systems, and practically banned foreign investment. As a result, the growth rate was far below the economy's potential, and a bloated government administration, unviable public sector enterprises, and recurring subsidy schemes to benefit the poor had bred financial indiscipline.

The Indian reforms proceeded on all fronts in July 1991 but in a gradualist mode. Cutting of the budget deficit, although on track, was slow-paced: the domestic debt-servicing burden constrained the reforming government's ability to lower the budget deficit, which remained at an annual average high of 6.2 percent of GDP from April 1, 1992 to March 31, 1996. Again, prices of important items (such as fertilizers and energy) continued to be administered. Consumer goods imports were gradually being freed from licensing requirements despite the introduction of current 
account convertibility. Tariff rates, though reduced, remained unduly high by 1996 . Privatization was barely begun. Labor market flexibility in hiring and firing was still a goal toward which no effective start had been made. But there was no doubt that the reforms were in place and would continue to expand in old and new areas over time.

The post-Soviet states belong to the group of low-speed reformers. Kazakhstan and Uzbekistan, both members of the ruble zone until the end of 1993, faced four-digit inflation at the start of the 1990s because macroeconomic stabilization policies were delayed under Gorbachev (1985-91) in Russia, which dominated the zone. Stabilization floundered in 1992 under acting Prime Minister Gaidar, in the end forcing Russian policy makers to employ a sustained regimen of fiscal discipline (which remained somewhat off target) and monetary control (which was increasingly on track).

Severe stabilization measures eventually became necessary in Kazakhstan and Uzbekistan, which began their transition in 1994 by adopting their own currencies. Kazakhstan's inflation control under IMF monitoring was in the end one of the sharpest among the transition economies. Its late start, with little done to reform the economy before 1994, qualifies it as a member of the low-speed category. Among the sample countries the pace of trade liberalization was the slowest in Uzbekistan, which was also a late starter with respect to inflation control.

Finally, it is not enough for the analysis I undertake below to assign countries to these three groups. I need to rank order them within the groups, a task that also raises some judgment calls, for instance, when I have to address two countries with similar transition agendas. For example, does Poland rank ahead of the Czech Republic within the high-speed group?

Recall that I assess reform speed according to the announcement and pursuit of the 
comprehensive, ideal reform package as well as the timing thereof such that earlier is better. Of the six high-speed candidates, four--Poland, Estonia, Latvia, and Lithuania--starting with triple- or quadruple-digit inflation rates, adopted rigorous programs of orthodox stabilization consisting of the five key components I have outlined. The Baltic lands also broke away from the ruble zone, introduced their currencies, and, like Poland, unified their exchange rates and liberalized their trade regimes, led by Estonia and followed by Latvia and Lithuania, in that order, in the rigor and timing of the necessary measures. The highly comprehensive Czech reform program was, however, less demanding, being called upon to tame a much lower inflation rate of 56 percent in 1990. I therefore rank it after Poland, Estonia, Latvia, and Lithuania. Finally, if timing and speedy inflation control were the only criteria, Vietnam could have been at the top. It was, however, placed in the last position in the group because its policy package, announced in 1989, lacked full dimensionality by failing to pursue trade liberalization and privatization with any determination or success. ${ }^{9}$

The medium-speed countries--Hungary, India, and China--which avoided the swift, simultaneous reform strategy, are rank-ordered on the basis of the market orientation of their transition in 1991. The Indian reform package of the summer of 1991, consisting of a unified and (current account) convertible currency, removal of restrictions on private investment, abolition of quantitative trade restrictions (except licenses for consumer goods imports), and reduced import tariffs was more liberal than comparable 1991 measures in China. Hungary's reform momentum in 1991 was ahead of the pace in both the Asian economies.

Finally, Russia, Kazakhstan, and Uzbekistan belong indisputably to the group of low-speed reformers, with Russia at the top and Uzbekistan at the bottom: Russia has moved more quickly than the other two, and more decisively on privatization, for instance; Uzbekistan has lagged seriously 
in starting reforms and has mainly opted for stabilization rather than a wider range of reforms.

Having allocated the countries to the three categories, and ranked them as well, I now proceed with the substantive analysis. In particular, I do the following:

* Note several commonalities of experience that cut across nearly all countries and the three groups

* Examine the differing levels of global integration achieved by the various countries at the end of the period by developing four different indicators ${ }^{10}$

* Rank-order countries by their speed of reform (just accomplished above) and by their performance on these indicators of global integration (to be done below), and examine whether greater speed leads to greater globalization

* Undertake similar correlations between rank ordering in terms of speed and in terms of indices of unemployment, inflation, and growth rates, to determine whether greater speed is associated with better within-period economic performance, thereby promising better future performance

* Reach broad judgments on the general question of the relationship between transition strategies and globalization.

\section{Common Features of the Transition by the End of 1995}

As 1995 closed, nearly all economies were marked by a few common achievements and failures in regard to the management of inflation, freeing of prices, reform of the exchange rate and trade regimes, growth performance, and unemployment rates. I review these before turning in the next sections to an analysis of the significant differences. 


\section{Prices and Inflation Control}

Almost all prices (except those of household utilities) had been freed everywhere except in the Asian and the three post-Soviet economies. The exceptions in the latter group related mostly to prices of important raw materials: of energy in India, Russia, and Kazakhstan; of fertilizers in India; and of cotton and grain in Uzbekistan, which continued to diverge from world prices toward the end of 1995 .

In China and India, inflation had always been modest, though India had begun its reforms under a cloud in this regard and would bring inflation firmly back under control, to under 5 percent annually, by fiscal 1995-96 (from April 1 to March 31). Everywhere else, extreme inflation and even hyperinflation had been the inherited state. And everywhere it was in turn brought down from these extreme levels. Nonetheless, high inflation persisted in 1995, with double-digit inflation rates afflicting the European and Asian economies while triple-digit ranges persisted in the post-Soviet states (in contrast to the earlier four-digit levels).

Real interest rates were positive in all the economies, and the policy makers had moved away from direct methods of credit control. However, except in the Czech Republic, they struggled with high fiscal deficits (as a proportion of GDP). Budgetary expenditures ran ahead of government revenues. ${ }^{11}$

The inflow of foreign funds in varying amounts, especially of short-term capital, aggravated inflationary pressures in most economies. The gradual emergence of relatively high real interest rates attracted capital inflows, occasionally requiring authorities to switch to a new mode of foreign exchange management (as in the Czech Republic) or undertake capital control measures (as in India toward the end of 1995 and stretching into early 1996). ${ }^{12}$ At the same time, some (the Baltic states, 
in particular) encountered difficulties in neutralizing the extra money supply (generated by the inflow of foreign funds) because their financial institutions could not undertake effective sterilization.

\section{Exchange Rate Management}

All exchange rates had been unified and made convertible for current account transactions. However, the requirement that export earnings be surrendered at the prevailing market rate, fully or partly, sooner or later, to a state agency or a commercial bank had continued except in the Czech Republic, the Baltic states, and Kazakhstan, in which it was abolished in 1995. Policy makers in the remaining countries had announced plans to remove the surrender requirement and advance toward complete current account convertibility in 1996 or later.

The nominal exchange rates had declined everywhere, whereas the real exchange rates had been appreciating for most of the period under consideration. ${ }^{13}$ (Monthly rates of real exchange rate movements are stated in Table 1.) The only exceptions were Uzbekistan (where the sum had depreciated in terms of the ruble) and Vietnam (where the dong had decreased slightly in terms of the dollar). This reflected the fact that the inflation rate differential at home and abroad had kept ahead of the rate of depreciation in the nominal exchange rate.

The monthly rate of currency appreciation moved closely with the country inflation rate. In other words, low inflation economies generally experienced lower rates of real exchange appreciation (Table 1). The appreciating real exchange rate, however, had negative implications for the competitiveness of exports and import substitutes, in turn creating problems for those involved in trade policy management. 


\section{Foreign Trade}

At the end of 1995, tariff barriers were still high everywhere, having been reduced and then raised again or not reduced significantly to begin with. Thus, except in the Czech Republic and Estonia, tariffs were being raised in the European countries. The Asian economies had high tariffs with only a lowering of the initial extreme rates (with continuing quantitative restrictions in China and bureaucratic impediments in Vietnam despite the current account convertibility). The post-Soviet states maintained high import tariffs (in Russia), some export quotas and taxes (despite progress in removing them in Russia and Kazakhstan), and state orders of tradables at distorted prices (in Uzbekistan).

Almost all countries had formed "spaghetti bowls" of crisscrossing bilateral trade agreements as they sought regional trading advantages.

\section{Growth Rates}

The growth rates of GDP had improved in all countries, having turned around from negative rates, or plateaued at negative levels, or increased from high or low positive levels.

Thus, growth rates had bounced back to positive values after sharp drops in the European economies and had bottomed out, still in the negative range, in the post-Soviet subset. China and Vietnam, both high growth performers, did not experience a recession, but the Indian growth rate had dipped to 0.9 percent in fiscal 1991/92.

\section{Unemployment Rates}

Unemployment rates had risen everywhere in the European countries except the Czech Republic. Policy makers in the Asian economies (which traditionally have high disguised unemployment in their massive rural sectors) were strongly pressed to continue financial support of 
state-owned industry in order to maintain employment of the organized "labor aristocracy" in the urban sector.

\section{Reformers at Risk}

Halfway through the transition period in some of the European economies (Poland, Hungary and the Baltic states) and by mid-1996 in the others (the Czech Republic and Russia, despite Yeltsin's reelection as president), reformers were either out or in a minority in coalition governments or legislatures. As a result, progress in market reform had to be balanced with concern for societal welfare. The "window of opportunity" for reform had narrowed, and the days of "extraordinary politics" had receded into the past.

Similar pressures for moderating the social costs of the transition were of concern to the authoritarian leaderships of post-Soviet Kazakhstan and Uzbekistan, and also of Communist China and Vietnam, which opened the reform "window of opportunity" selectively. ${ }^{14}$ The Indian reformers were turned out in 1996; however, the reasons are complex and the new Indian government cannot be interpreted as being "antireform."

An analysis of the interaction between the politics and the economics of the transition is beyond the scope of this essay. However, the rebound of the positive, and the bottoming out of the negative, real GDP growth rates during the attempted transition must be weighed against the unemployment record (as I do later) ${ }^{15}$ for an objective assessment of the performance of the real economy, as well as for distinguishing between desirable and feasible reform speeds (a distinction the World Development Report 1996 overlooks).

These common features notwithstanding, the sample countries have undoubtedly integrated into the world economy at varying speeds, this integration or globalization being the central concern 
of the present volume. I now turn to selecting the indicators of globalization before anything more can be said about the factors contributing to it in the transition economies' actual experience.

\section{Going Global: The Indicators}

A fully open economy can be defined as having a convertible currency (on current and capital accounts) and a trade regime without tariffs and nontariff barriers. At the other end of the spectrum, an economy may have an exchange rate that is neither unified nor convertible on the current and the capital accounts. The tariff barriers may also be high, though quantitative restrictions (QRs) effectively constrain imports. Export taxes and restrictions also may obtain. For nonmarket economies, state trading organizations may constitute effective trade-restrictive devices.

The economies under consideration here fall somewhere in between. The question is: how does one assess their relative openness or global integration? Short of building computable general equilibrium (CGE) models within which the counterfactual of free trade may be compared with the reality, a procedure that is itself subject to massive errors and conceptual fudges in implementation, we have to go by satisficing but not altogether satisfactory proxies. I propose here to adopt five indicators.

First, I pick three indicators that reflect the implementation of appropriate policies. They are fairly obvious and plausible: convertibility of the currency, liberalization of the foreign trade arrangements, and the creation of a positive climate for attracting foreign direct investment (FDI). A country with a fully convertible currency, which in turn requires decisive inflation control, gets the top billing. ${ }^{16}$ Next, a country with a liberal trade regime marked by low import tariffs and minimal export taxes or subsidies also acquires a top policy ranking. Finally, a positive environment to attract FDI that is characterized by suitable tax incentives, adequate financial and physical 
infrastructure, and continuing restructuring of industry puts a country ahead in the ranking. I rank all countries according to their policy regimes in these three areas in 1995.

The next two indicators relate to performance reflecting, ceteris paribus, these policy frameworks. Thus, greater integration may be defined in terms of an economy's greater trade participation--more precisely in terms of the familiar ratio of exports plus imports to GDP. Given the fact that the transition economies' trade had been severely restrained and also diverted to countries within the socialist bloc, increased integration into the world economy may also be usefully indicated by trade diversification, measured by exports to OECD countries divided by total exports, or additionally by increment in the ratio of their exports of manufactures (now increasing in volume) to their total exports to OECD markets. In fact, I rank the countries according to their OECD market penetration via manufactured goods exports during 1991-95. The second indicator that I use is based on FDI inflows. It ranks the countries according to their FDI inflows as a proportion of gross fixed investment in the latest available year. ${ }^{17}$

\section{Going Global: Ranking by Policy Outcomes}

\section{Country Ranking by Exchange Rate Regime in 1995}

I begin with an analysis of the transition economies' effectiveness in making their currencies convertible. A unified exchange rate and fully convertible currency are necessary for facilitating efficient trade flows and promoting foreign investment (although, as I shall argue later, FDI can flow in as long as profits and the principal are allowed to be repatriated freely). How do the countries rank in that regard?

The information on currency convertibility and the rankings of the exchange rate regime are presented in Table 1. (Recall that East Germany and Finland are omitted from the entire comparative 
analysis in this Introduction. It may be noted, however, that the East German currency was converted one-for-one with the fully convertible deutsche mark in a single step. As for Finland, as soon as the bilateral trade arrangements with the FSU were terminated in 1991, the Finnish markka started functioning as a convertible currency in trading activity with the East, as it had done with the West.) Four clarifications about the methodology underlying the country rankings by their foreign exchange regimes in Table 1 are necessary before I discuss the countries in some depth.

First, effective inflation control in line with the inflation rate of trading partners and of rival suppliers translates into a stable and fully convertible currency. This fosters foreign trade competitiveness and, barring exogenous shocks (such as the sudden loss of COMECON markets by the East-Central European transition economies), is an invaluable aid in creating and sustaining a healthy current account balance. Therefore, the ranking by the indicator of exchange rate convertibility is not independent of the ranking of the country by the efficacy of its macroeconomic policies. Since my view is that by and large, the five policy reforms that I have distinguished above tend to reinforce one another's efficacy in promoting efficient transition, this also holds true for such other policies as privatization, which can help external accounts by attracting FDI flows. ${ }^{18}$

Second, I should stress that the ranking is independent of whether the nominal exchange rate is fixed or whether an economy has alternative arrangements (such as a preannounced crawling peg or a managed float) that allow its policy makers flexibility in the conduct of monetary policy. ${ }^{19}$ In fact, only the Baltic economies currently operate under a fixed exchange rate regime supported, if necessary, by central bank intervention. The Czech koruna is fixed within a band (which was widened in February 1996). Thus, a variety of exchange rate regimes is compatible with the presence of convertibility. 
Third, we need also to take into account the possible fragility of the exchange rate management before assigning ranks to countries based on their relative success. Thus, for example, aggressive macroeconomic management to control inflation may encourage policy makers to adopt a fully convertible currency. However, the resulting higher unemployment (as I discuss in a later section) or real wage decline may in turn generate political pressures forcing them to reverse the decision down the transition road.

Therefore, an economy with a fully convertible currency may be grouped in the same class as another with a fully convertible currency; it is, however, ranked lower if its unemployment rate is higher even though its real GDP growth rate is similar or slightly higher.

Fourth, the ranking, which I ultimately report in the final column of Table 1, is influenced by pointers to fragility of the exchange rate regime that are suggested by "external" indicators such as the current account balance and debt servicing ratio (both listed in Table 1). The Mexican peso debacle, precipitated by a combination of circumstances including a deteriorated current account balance and a huge short-term debt overhang, provides a solid example in support of such a procedure (which I state below).

Effective foreign exchange management and the progress to currency convertibility in these reforming economies have been hampered by widely differing exogenous factors, such as the legacy of high foreign debt and by the collapse of the COMECON export market, which was not compensated for by exports to Western Europe because of recession. ${ }^{20}$ Again, as growth and imports have picked up, the trade balance has been put under varying stress. Export growth, ceteris paribus, has had to be unusually robust to make up for lost markets, to cover foreign debt obligations, and to finance growing import needs. The final ranking of countries by the 1995 exchange rate regime 
in the last column of Table 1 is thus adjusted informally by these "fragility concerns" where relevant.

Thus, the central point in the context of comparing the cross-national currency covertibility performance is that although inflation has been brought down everywhere (as I noted earlier), the impact of the macroeconomic policies on the real economy--that is, on the real GDP growth and unemployment rates--has differed from country to country, with varying implications for the policy makers' ability to launch full currency convertibility by slashing inflation further. Therefore, I begin with an analysis of the impact of inflation control policies on the real economy, which in turn slowed the adoption of full currency convertibility (via a slackening, for example, of budget deficit control). I then discuss the role of the external factors that, interacting with the appreciating real exchange rates and growth-led import demand, put excessive stress on the foreign exchange regime, resulting once again in the postponement of full currency convertibility.

\section{The Real Economy and the Uneven Progress toward Convertibility by 1995}

Take the East-Central European and Baltic economies first. They have bounced back to positive GDP growth rates but the unemployment rate has varied. (These details are in Table 1. Country GDP growth and inflation rates are also presented in Figures I.1 and I.2.) As a result, the policy makers' ability to press on with macroeconomic tightening has varied from country to country.

The Czech Republic is ahead of the rest in this group because its GDP growth rate was 5.2 percent in 1995 and its unemployment rate was a low 3 percent of the workforce, in fact a remarkably steady 3 percent through 1995 . By contrast, Poland's high growth rate, rising to 7 percent in 1995, was accompanied by an unemployment rate escalating from 6.1 percent in 1990 to 16 percent in 1994. In the Baltic states, the situation was similar with rising unemployment; Estonia 
dominated with a 6 percent GDP growth rate in 1995. Hungary performed worst on all scores: a low GDP growth rate ( 2 percent), a high unemployment rate (10.4 percent) and an inflation rate of 28.2 percent in 1995. In consequence, it gets the lowest ranking on foreign exchange regime ranking within the European (including the Baltic) group.

China, India, and Vietnam, the three Asian economies, have high GDP growth rates (with China having a double-digit 10.2 percent), relatively low inflation rates, and manageable unemployment problem (which is disguised in the rural areas but has to be monitored carefully with regard to the urban workforce). Another major contrast is that the three economies have grown through the transition without a recession, except for a 1991 dip in India. I therefore rank China, Vietnam, and India in that order, on the basis of their macroeconomic management and the resulting 1995 foreign exchange regime.

Finally, among the three post-Soviet states, Russia, Kazakhstan and Uzbekistan have continued to have negative growth rates, triple-digit annual inflation, and rising unemployment. Kazakhstan's record of inflation control under a painful IMF regime of shock therapy has brought it to the forefront, with a current account convertible exchange rate regime in 1995, achieved in less than a year. The ranking in this subset is therefore led by Kazakhstan, followed by Russia and Uzbekistan.

\section{External "Fragility" Factors and the 1995 Foreign Exchange Regime Rankings}

These rankings must be adjusted for the "fragility" factors on the external front: the state of the current account balance and the debt servicing ratio.

As I have already noted, exogenous factors such as the legacy of high foreign debts and the sudden loss of COMECON markets in 1991, stretching into 1992, have affected different countries 
differently. (Details are in country chapters.) For example, Russia, India and Hungary continued struggling with market transition while confronting inordinately high foreign debt burdens. Some of Poland's debt was written off. Much of Russia's Soviet debt had been rescheduled. Hungary sharply added to its foreign debt as the transition proceeded.

The negative effects of the breaking of trade links continued throughout the period for the post-Soviet states, especially Kazakhstan and Uzbekistan. The appreciating real exchange rate strained the foreign trade balance for every country except China. (Brada and Kutan, and Desai assess its impact for the Czech Republic and Russia, respectively, with the aid of export-supply and import-demand equations.) Economic recovery added to the stress via increased import demand.

How do the countries finally rank with regard to their exchange rate regime in 1995 when the impact of these influences, as reflected in the current account balance and the debt servicing ratio in 1995, are factored in?

Take first the current account balance as a percent of GDP. Omitting Uzbekistan and Kazakhstan (for which, along with Russia, I present separate non-FSU and FSU balances from IMF sources and discuss the problems of consolidating these accounts), Hungary had the worst record: its current account deficit had deteriorated to almost 10 percent of GDP in 1994, then recovered to 5.3 percent in 1995. By contrast, the Asian economies fared better, with the exception of a negative showing by Vietnam of 8 percent in 1995. Hungary therefore comes after the Asian economies in the final ranking of exchange rate regime management.

The remaining European economies (including the Baltic states) had an uneven but reasonably manageable current account record that is difficult to distinguish from country to country. Poland's rank remains behind the Baltic states because, with an almost similar inflation and real 
growth record, its unemployment rate escalated during the five years, constraining the adoption of more rigorous macroeconomic policies. Furthermore, the Baltic currencies, unlike the Polish zloty, are fully convertible.

Next take the record of debt servicing. Hungary performs worst, with a debt servicing ratio of 45 percent in 1995, preceded by Russia and India in that order. But for frequent rescheduling of debt repayment obligations, Russia's record would have been worse. Poland's ratio is only little worse than the Czech ratio because much Polish debt was written off. The Baltic states remain ahead of Poland in the final ranking because of their low debt servicing ratios.

In conclusion, I have judged the final ranking of the economies' 1995 foreign exchange regime, from best to worst, as follows: the Czech Republic, Estonia, Latvia, Lithuania, China, Vietnam, Poland, India, Hungary, Kazakhstan, Russia, and Uzbekistan.

Country Ranking by Trade and FDI Policy Regime in 1995

A fully convertible currency enhances global interaction by promoting trade and attracting capital flows. But this clearly is not sufficient. The trade regime has to be free, and the investment environment needs to be positive. I now rank the countries according to their 1995 foreign trade regimes (using the information in Table 2) and by the policies for attracting foreign direct investment by year-end 1995 (on the basis of the information in Table 3).

\section{$\underline{\text { Ranking by Foreign Trade Regime }}$}

I use three criteria for judging the pro-globalization characteristics of the trade regime. The first relates to the agents (e.g., private parties or state organizations) who undertake foreign trade; the second, to the continuing prevalence or elimination of nonmarket measures, including QRs and licensing requirements, for regulating trade; and the third, to the height and dispersion of import 
duties.

In the European and Baltic economies, private companies had replaced the former state trading organizations (STOs) more effectively than in the post-Soviet states. In Russia and (less so in) Kazakhstan, former STOs had been converted into joint stock companies in which the former party bosses were mostly in charge. Private traders (with a substantial role in Russia) had appeared in both countries.

In Uzbekistan, STOs still dominated foreign trade activity, and private trade was being controlled via export quotas and licenses. State orders in Uzbekistan dominated exports of cotton (which was bought by state agencies from domestic producers and sold at a higher price on the world market) and imports of grain (which was bought at the world price and sold at a lower price to domestic mills). Among the Asian economies, government agencies at various levels continued to be most active in China, less so in Vietnam, and least in India.

Nonmarket interventions also had diminished. They had disappeared in the European and Baltic economies except in Hungary, where import quotas remained on some consumer goods. Among the post-Soviet states, export quotas were allocated directly to private parties in Uzbekistan, whereas they were increasingly auctioned off in Kazakhstan. In Russia, quotas were being removed but they still operated in oil shipments via selective access to pipelines. Among the Asian economies, import controls were used in China to protect specific industries and licenses, which applied to a quarter of imports in 1992, were necessary. Import quotas had ceased to exist in Vietnam and in India as well, except that licenses were still necessary to import consumer goods. In Vietnam, state agencies were active in foreign trade and private traders faced bureaucratic hurdles.

If one goes only by two indicators--the continuing role of government trading agencies and 
the presence of quotas and licenses--then India was the most liberalized among the post-Soviet and Asian economies because it had the fewest state trading and nonmarket restrictions by 1995 . It was followed by Kazakhstan, Russia, Vietnam, China, and Uzbekistan. Kazakhstan and Russia rank ahead of Vietnam and China because, under persistent IMF pressure, they had (by the end of 1995) moderated their restrictive trade regimes whereas Vietnam and China had not. Hungary ranks as least liberalized among the European economies (including the Baltic states) because some import quotas still prevailed in 1995. The remaining (five) European economies had hardly any nonmarket interventions and rank at the top.

On the other hand, on the indicator of trade taxes and subsidies, the Baltic and post-Soviet states did not do so well. Export taxes (and quotas) were used to prevent the outflow of goods, especially to the neighboring states, and to maintain their local availability. These were being phased out in Russia, and had already disappeared in Estonia and Latvia. Lithuania had retained some export licensing, which placed it below the other Baltic states.

By contrast, import duties were much more important and had acquired a dominant role in trade policy management in 1995 , especially because the real exchange rate had appreciated everywhere except in Uzbekistan and Vietnam. (The import duties are shown in Table 2.) Note, however, that the rates are simple averages and generally unweighted by import shares of specific items or groups.

Even so, the pattern is unmistakable. In the European economies, except the Czech Republic, import duties had gone up, with the highest average rate in Hungary (which, as already noted, had also retained some import restrictions). Lithuania, among the Baltic states, had the highest import duty rates (especially on agricultural items) with large dispersion, again qualifying it for the lowest 
rank among the Baltic states. Among the post-Soviet states, Russia was marked by increasing import duties and escalating pressures from agricultural and food processing lobbies to raise them further. By contrast, Uzbekistan and Kazakhstan, both importers of essential consumer goods, had fewer import duties (but their trade regime, as noted earlier, was marked by a dominant role of state agencies and export controls; moreover, in Uzbekistan there were subsidies on the sale of imported grain for domestic users and taxes on domestic producers on exports of cotton).

The Asian economies had, on average, high import duty rates in 1995: 15 percent (average, unweighted, with massive dispersion) in Vietnam, 27 percent (average, trade-weighted) in India, and 31.9 percent (average, trade-weighted) in China. However, the Indian system, as already noted, was relatively the least encumbered by state trading and direct controls among the three.

Taking all features into account, ${ }^{21} \mathrm{I}$ judge the final ranking of the 1995 trade policy regime (with the almost free Czech Republic at the top and the least liberalized Uzbekistan at the bottom) to be as follows: the Czech Republic, Estonia, Latvia, Poland, Hungary, Lithuania, India, Kazakhstan, Russia, Vietnam, China, and Uzbekistan.

Ranking by Receptivity of FDI Environment (end of 1995)

Finally, I use the information in Table 3 for ranking countries in terms of factors that would influence and shape foreign investors' perception of the investment environment as 1995 ended.

An important consideration in this regard is the ease with which foreign investors can repatriate their profits and initial investment should they choose to do so. A fully convertible currency automatically guarantees such transfers. Repatriation of the invested principal was legally guaranteed everywhere, especially in countries in which the currency was convertible only for current account transactions. (Occasionally foreigners were not able to take profits out because of 
a shortage of foreign exchange, as in Kazakhstan and Uzbekistan.)

Other criteria that are relevant for potential foreign investors are the level of country infrastructure, physical and financial, and progress on restructuring of state-owned enterprises (SOEs) in industry. Infrastructure includes not only roads, railways, and telecommunications but also the investment underpinning provided by banks, stock markets, and financial intermediaries. More relevant are legal guarantees to investors, a predictable and transparent tax system, and tax incentives. (These details are collected in the Appendix.)

Take infrastructural features first. The European and Baltic economies were ahead of the Asian economies, followed by the post-Soviet states. The three European economies in turn dominated the Baltic states. Among the post-Soviet states, Kazakhstan and Uzbekistan were further handicapped by their landlocked position. Russia, therefore, leads Kazakhstan and Uzbekistan.

Industrial restructuring, on the other hand, among the European-Baltic group was speediest in Estonia followed by Hungary and Latvia. Lithuania had made the least progress. Toward the end of 1995 , Hungarian policy makers' midyear austerity program and the strengthening forint had revived foreign investors' interest in seizing attractive investment opportunities in the economy. The Czech policy makers, blessed with low inflation and an appreciating koruna, encouraged FDI selectively for upgrading technologies. The three post-Soviet states continued to be hampered by insider ownership and soft budget constraints. Among the Asian economies, India had made a slow start in the sale of state-owned assets but faced problems of labor layoff in privatized units. Neither China nor Vietnam had begun the process of restructuring SOEs.

Absence of enterprise restructuring need not deter foreign investors if they can find profitable opportunities supported by large markets for new ventures. China, in sharp contrast with India, 
successfully played the market-size card by offering concessions to foreign investors in new projects and joint ventures in the special economic zones. Thus investors' negative perception with regard to infrastructural handicaps and slow SOE restructuring in China was overcome at the outset by the size of the market accompanied by decisive investment incentives.

Increasingly, however, infrastructural bottlenecks, procedural red tape, and political pressures to overstaff (all of which are pervasive in state industries) can deter foreign investors from remaining engaged. Thus the FDI momentum, fed by incentives and investment opportunities in new industries, needs to be sustained by subsequent infrastructure buildup and SOE restructuring. In China and Vietnam, the initial phase was marked by positive incentives to foreign investors up to the end of 1995; India, by contrast, continued giving mixed signals. The next phase of infrastructure creation and SOE overhaul is only emerging in the Asian economies. By contrast, the European and Baltic policy makers sought FDI to simultaneously promote SOE restructuring and infrastructural upgrading (especially of telecommunications and the financial sector) at the start of the transition. Desire for speedy entry into the European Union prompted this pattern.

Past contacts, physical location, and cultural-ethnic affinity also have contributed to a varying assessment of FDI potential by would-be investors. Note the dominance of overseas Chinese investors in China via Hong Kong; the Finnish groups in the Baltic states, especially in Estonia; the West Germans in East Germany; and the ASEAN countries in Vietnam.

Finally, the reforming policy makers' view of the role of foreign investors in the local economy, which is conditioned by complex economic and political factors, is relevant. The Baltic policy makers' assessment of Western European investment participation in industrial restructuring is benign, more so to obliterate the malign impact of the Soviet-era exploitation. The Czech 
reformers have been rather selective, compared with the Hungarian, in offering restructuring opportunities to foreign investors, out of a sense that local business can manage the task. The approach of Kazakh authorities is pragmatic and well-focused, in contrast to the chaotic policy mess in Russia and the small, selective start in Uzbekistan. The Chinese and Vietnamese Communist leadership pursued an aggressive early strategy of inviting foreign investors in contrast to the "you can, you can't" approach of India's policy makers.

Taking all aspects into account, I judge that the country ranking of foreign investors' perception of investment environment toward the end of 1995 was most favorable for China, followed by Estonia, Hungary, the Czech Republic, Latvia, Poland, Vietnam, Lithuania, Russia, Kazakhstan, India, and Uzbekistan.

Having thus ranked countries according to the three policy indicators--their 1995 exchange rate and trade policy regimes, and the policy-led foreign-investor perception by the end of 1995--I turn now to an assessment of the two performance indicators regarding globalization: one relating to trade flows and the other concerning FDI inflows.

\section{Going Global: Ranking by Flows}

All countries, according to the contributors, have oriented their foreign trade away from intra-CPE confines.

\section{Country Ranking by Foreign Trade Flows in 1995}

Noting that all countries have reoriented their foreign trade away from intra-CPE confines, and have moved away from autarkic orientation that crippled their trade in many cases, I present three indices in Table 4 for measuring successful globalization in trade, reflecting these transition economies' trade participation ratios and diversification in trade toward the hitherto neglected and 
highly competitive OECD markets by 1995 .

Trade participation in terms of the familiar $(\mathrm{X}+\mathrm{M}) / \mathrm{GDP}$ ratio is well known to be problematic because exports and imports in the numerator are measures of gross output, whereas GDP is gross value added; the ratio thus has incommensurate items in the numerator and the denominator. Here, this conceptual problem is compounded by insufficient information for the chosen countries. The ratios that could be calculated show a definite trend toward increased globalization for Hungary in Europe, and for China, Vietnam, and India in Asia. Compared with 1990, Hungary's trade participation had gone up by 72 percent in 1995, Vietnam's by 58 percent in 1995, China's by 50 percent in 1994, and India's by 30 percent in fiscal 1994/95.

I measure the economies' trade orientation toward OECD markets with two other ratios. The first represents the share of an economy's exports to OECD markets relative to its total exports. The available data show a rising share for all countries except India (for which, having long been trading with OECD countries, the ratio is not a helpful guide because India already had a very high share of 57 percent at the outset), and Russia (for which the ratio shows a declining trend from 1991).

(iii) The second trade orientation ratio measures the share of manufactured exports to OECD in a country's total exports to OECD. These ratios (with adequate information only for Russia among the Baltic and post-Soviet states) again show a rising trend (again except for India, which began and ended with a high ratio of 74 percent, and Russia stagnating in a low range of 7 to 11 percent during 1991-95).

In the end, lack of adequate data for all the three indicators handicapped the ranking of a sufficient number of the countries studied to enable me to say anything meaningful for comparative analysis. Nonetheless, Table 4 presents an export performance ranking for five countries, based on 
the second orientation indicator described above, and the ranking is according to the rate at which a country increased its share of manufactured goods exports in its total exports to OECD markets in the first half of the 1990s. In other words, I measure a country's effective trade orientation in terms of the speed with which it has diversified its OECD export basket toward manufactured goods. Such a shift provides an appropriate index of an economy's ability to push exports in OECD markets toward manufactured products, in which competition is acute and from which the earlier autarkic policies had particularly diverted trade. China ranks at the top (with an annual growth in its ratio of manufactured goods exports to OECD/ exports to OECD of 10.5 percent), followed by Poland (10.25 percent), Hungary (6.4 percent), the Czech Republic (6.2 percent), and India ( 0.2 percent). But, frankly, little of value can be inferred from this fragmented set of statistics, and so, beyond claiming the advantage of this and the other two indicators set out above, I must refrain from making any inferences about the comparative pace of globalization on this dimension.

\section{Country Ranking by FDI Flows in 1993-1995}

Actual FDI flows are presented in Table 3 in terms of two indicators: each country's share of total FDI flows to non-OECD countries and FDI contribution to gross fixed investment in the economy.

China clearly has a lion's share of FDI flows into non-OECD countries at 31.4 percent in 1993. Contrast that with India's share of 0.71 percent! Hungary claimed 2.7 percent of non-OECD FDI in 1993 and reached 5.2 percent in 1995. Vietnam's share in 1995 was 1.6 percent. All other shares are below 1 percent.

FDI's relative contribution to gross fixed investment in the economy, which therefore adjusts for a country's scale, provides a more meaningful comparison. The share was 68.7 percent in 
Hungary (in 1995), 43 percent in Estonia (in 1993), 28.2 percent in Latvia (in 1994), 28.2 percent in Vietnam (in 1995), 19.7 percent in China (in 1994), 7 percent in the Czech Republic (in 1993), 5.1 percent in Lithuania (in 1994), 4.2 percent in Poland (in 1993), and 1.4 percent in India (in fiscal 1993/1994).

In the end, given these two globalization indicators of FDI outcomes, I have chosen the latter as the more apt. I have therefore ranked the countries in the order suggested by that indicator, with Hungary leading the pack..$^{22}$

\section{Comparative Performance: Some Key Results}

We now have the rankings of the countries by their policy outcomes in regard to exchange rate and trade policy regimes, as well as the foreign investors' (end of 1995) perception of FDI opportunities offered by the host country policies. We also have the performance index for the FDI share in gross fixed investment (for the latest year). ${ }^{23}$ They are are pulled together in Table 5, which also rank-orders the countries by their GDP growth rates in 1995, the unemployment rates in 1995, and three indicators of the inflation rate: in 1995, decline over the entire reform period terminating in 1995, and decline in a year from its peak during the period (to gain some rough-and-ready insight into whether inflation was slashed more readily at the outset in one country than in another).

The pairwise rank correlation coefficients, in the final rows of Table 5, are computed between the rank order of the countries on the speed of their reforms and the nine indicators in the other columns just described. Armed with these, and the qualitative knowledge gained from the country analyses, I can now reach some key conclusions.

Reform Speed and Growth, Inflation, and Unemployment

The 1995 GDP growth rates and decline in the inflation rate over the transition 
period--remember that the period terminates in 1995 but the transition is often not complete, hence the question of "fragility" that is raised pointedly in this Introduction--happen to correlate nicely with speed of reform. The coefficient of correlation between reform speed and 1995 GDP growth rate rankings is 0.87 when the three Asian economies (which did not experience an output decline) are omitted. (See Figure 3.) That between reform speed ranking and country ranking in terms of inflation decline over the period is 0.75 when China and India (which did not experience high inflation) are omitted. These conclusions also are reached in the World Development Report 1996, which independently ends on the same general note. ${ }^{24}$

On the other hand, the conclusion must be qualified somewhat in regard to inflation control. Alternative associations of reform speed with country ranking according to the 1995 inflation rate (with a coefficient of 0.62 ) and according to decline in the inflation rate from its peak to the next year in a single swoop (with a coefficient of 0.50 ) are rather weak. Thus, speedy liberalization strategy goes well with declining inflation during the transition in a gradualist mode, but not so well with knocking it cold in a single year or bringing it down to low levels in the final year. In other words, reform speed may bring down the inflation rate but still not adequately tackle the job relative to gradualist policies.

But the real problem is that speedy reform and lower unemployment rates in the final year do not go together. The rank correlation coefficient between reform speed and 1995 unemployment rate rankings (omitting the three Asian economies, which present problems of defining and measuring unemployment) is negative at -0.25 (although statistically not significant). (This relationship is presented in Figure 4.) Thus speed is good for growth turnaround but may result in higher unemployment, raising problems for policy makers who must weigh the alternative reform 
agendas.

Indeed, on a closer look at country analyses, one can argue that the speedy reform countries have generally experienced higher unemployment rates, whereas the gradualist reformers, especially when confronting acute stabilization problems, seem to have had lesser growth rates but better unemployment outcomes. Thus, the rank correlation coefficient between the 1995 growth rate and unemployment rate rankings is negative at -0.15 (although it lacks statistical significance). Figure 5 suggests this tendency, indicating the presence of a trade-off, when the rankings of countries on GDP growth rates are related to their rankings on unemployment rates in 1995.

Such a trade-off implies two things: first, speedy reforms may produce better outcomes, like growth and globalization (which I analyze below), but they may come at the cost of short-run unemployment; second, that rising unemployment may itself engender the sustainability of the reforms by provoking a political reaction.

To underline this conclusion, consider the case studies of two contrasting sets of high-speed reformers, the Czech Republic, Vietnam, and East Germany, on the one hand, and Poland, Estonia, Latvia, and Lithuania, on the other. The former group either avoided the trade-off or managed it due to special circumstances, whereas the acute trade-off between GDP growth and unemployment rates in the latter group may still be persisting.

The speedy growth turnaround of the Czech Republic, marked by a steady and low unemployment rate, resulted from the initial favorable macroeconomic conditions, which helped policy makers immeasurably. Brada and Kutan warn against drawing hasty conclusions from the Czech experience with a view to transplanting it elsewhere. Vietnam emerged as a high-growth performer with a manageable unemployment rate bypassing the output decline of high-speed 
transition because of benign initial circumstances of a different order. According to Dollar and Ljunggren, the large agricultural, private service, and manufacturing sectors (which traditionally did not receive any credit from the formal banking sector or subsidies from the budget) responded energetically to the incentives of price liberalization and inflation decline of 1989. Finally, the fast and full economic, monetary and social union of East Germany with West Germany, described by von Hagen, was predicated on the willingness of West German taxpayers to bear the costs of the safety net provisions for the East German unemployed via massive transfers that were to be made available immediately as specified in the Unification Treaty. No other transition economy could count on such a well-timed, credible, and substantial resource transfer from a "rich uncle" next door for overcoming the resistance of the unemployed to fast-paced reforms.

By contrast, Poland and the Baltic states, the celebrated cases of shock therapy, traveled from negative to positive GDP growth rates in the midst of rising unemployment and sagging macroeconomic stabilization as 1995 ended. In fact, the rank correlation coefficient between GDP growth rate and unemployment rate rankings in 1995 for the four economies is negative at 1! The two rankings get perfectly reversed. (Also see Figure 5.) Indeed, the combination of high inflation (ranging from 25 to 35 percent) and high unemployment rates leaves one wondering if these so-called star performers have left the transition trade-offs behind them and emerged as the hoped-for high-growth-rate, fast-job-creating economies.

\section{Reform Speed and Globalization}

I finally consider the correlation between ranks by reform speed and ranks by the four indicators of globalization in Table 5. These are the foreign exchange and trade regimes in 1995, the FDI environment by the end of 1995, and FDI share in gross fixed investment in the latest 
year.

The first question relates to the association between the speed of reform and of globalization: does speedy reform lead to speedy globalization? The second issue focuses on the nature of globalization itself: do its four components move together? An important caveat qualifying this analysis is that it is based on the three policy outcomes in 1995 and a single indicator of FDI flows representing actual integration. Recall that I had to drop the trade penetration index because of insufficient information.

First, the estimated, pairwise correlations between reform speed ranking and the globalization performance rankings (ranging from 0.52 to 0.74 in Table 5) are reasonable enabling me to conclude that speed pays off in terms of increased globalization. This is not surprising because the policy package that qualifies a country to be assigned to a higher-speed category typically consists of policies that can be argued to lead together to increased and efficient integration of the transition economies into the world economy. And reformers are judged to be high-speed not only when they have attempted to go fast but also when they have stuck to their policies in the teeth of transition trials.

Next, has globalization proceeded in lock step? Note that each indicator cannot be expected to correlate strongly with every other. But the pairwise coefficients (in the final three rows of Table 5) suggest that globalization outcomes of policies and of FDI flows by 1995 are well coordinated. The exception here is the small and (statistically) insignificant impact of trade policy regime on FDI environment and flows.(The coefficients are 0.46 and 0.48 .) In other words, foreigners' perception of investment opportunities and FDI flows do not seem to depend on the host country's trade liberalization successes (witness China and Vietnam). On the other 
hand, an exchange rate regime marked by a convertible currency in place evidently plays a role in enhancing foreign investors' positive view and actual response. (The coefficients are 0.66 and 0.61.) The exercise also suggests a link between the foreign exchange and trade regimes in 1995 . (The estimate is 0.69.) In other words, transition economies, which were ranked ahead in terms of their foreign exchange regimes in 1995 (for example, the Czech Republic and the Baltic states), were more or less similarly placed in the sequence with regard to their trade regimes.

In conclusion, the policies of the sample countries that opened them into the world economy were, on the whole, well coordinated by 1995 .

\section{Summing Up}

Let me recapitulate the principal conclusions:

* Speedy reforms, with comprehensive policy changes in tandem, appear to promote both higher growth and faster inflation control while also increasing globalization;

* But speedy reforms also seem to create a short-run trade-off via an adverse impact on employment;

* Thus, speedy reforms, once such a trade-off is present, are not necessarily superior to less ambitious, gradualist reforms that impose fewer short-run difficulties and hence create a smaller risk of reversal;

* Where this risk is judged to be unimportant, and the short-run costs are also deemed to be socially acceptable in the pursuit of successful transition, the choice of speedier reforms is desirable;

* In that instance, rapid globalization also turns up as a distinct possibility. These general conclusions emerge from the rich details that each country analysis offers. 
At the same time, they complement these analyses, providing the textured backdrop against which each country's transition experience can be studied and savored. 


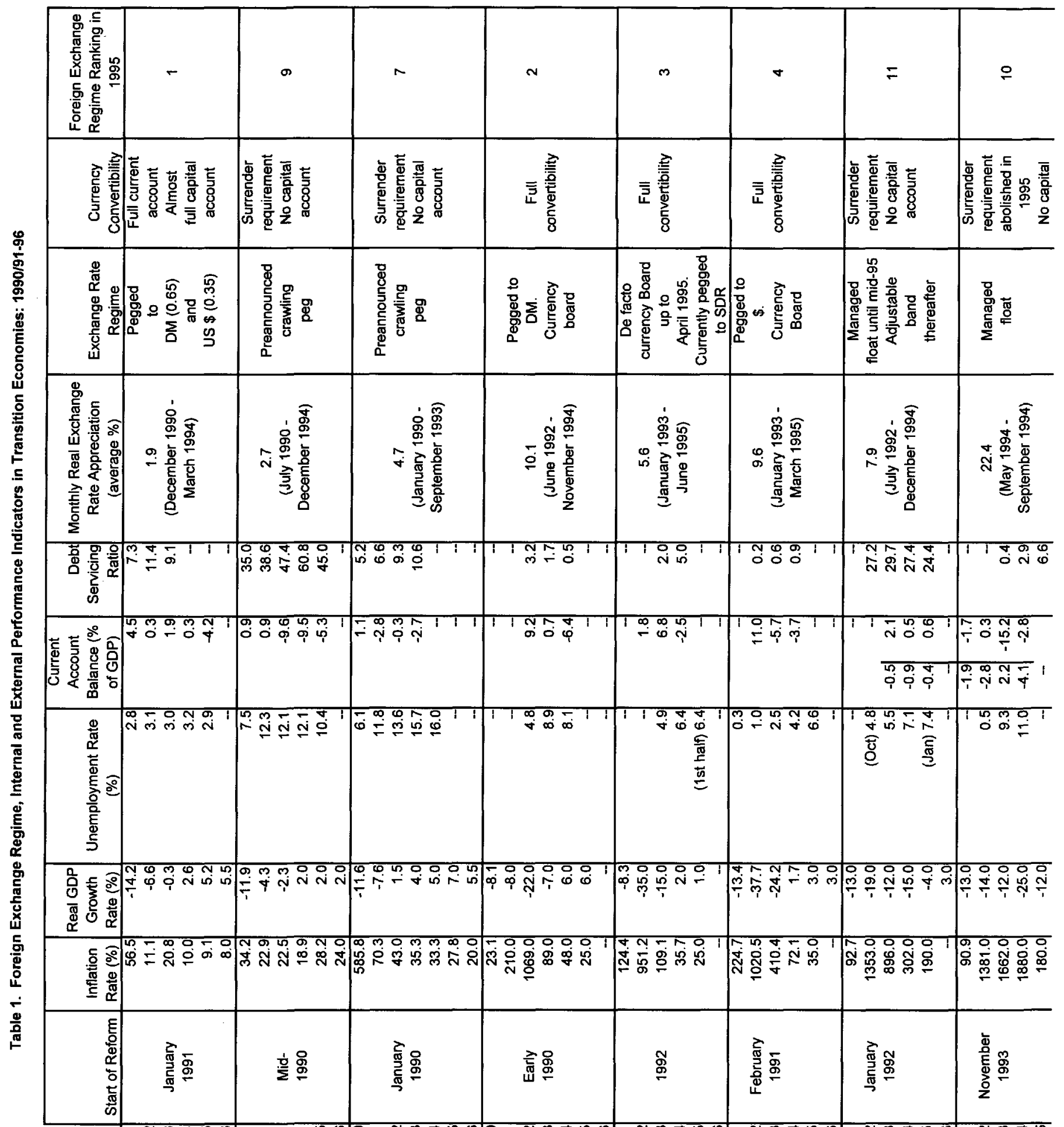

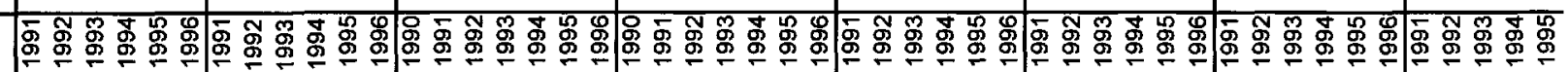

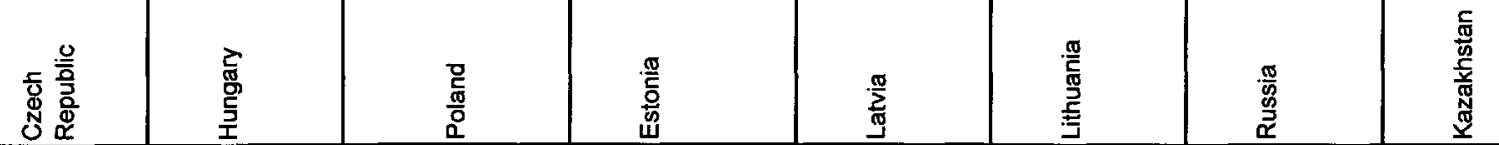



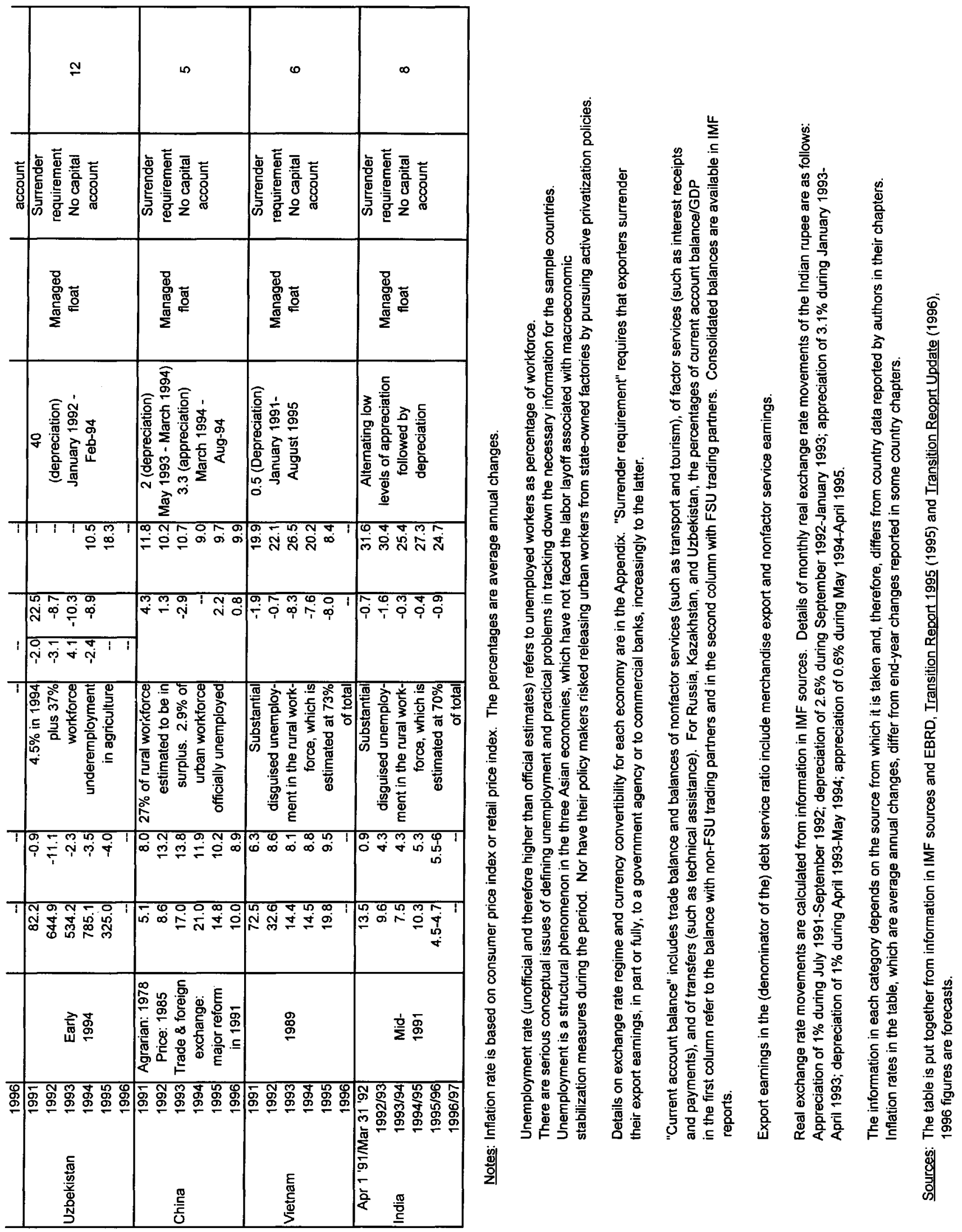


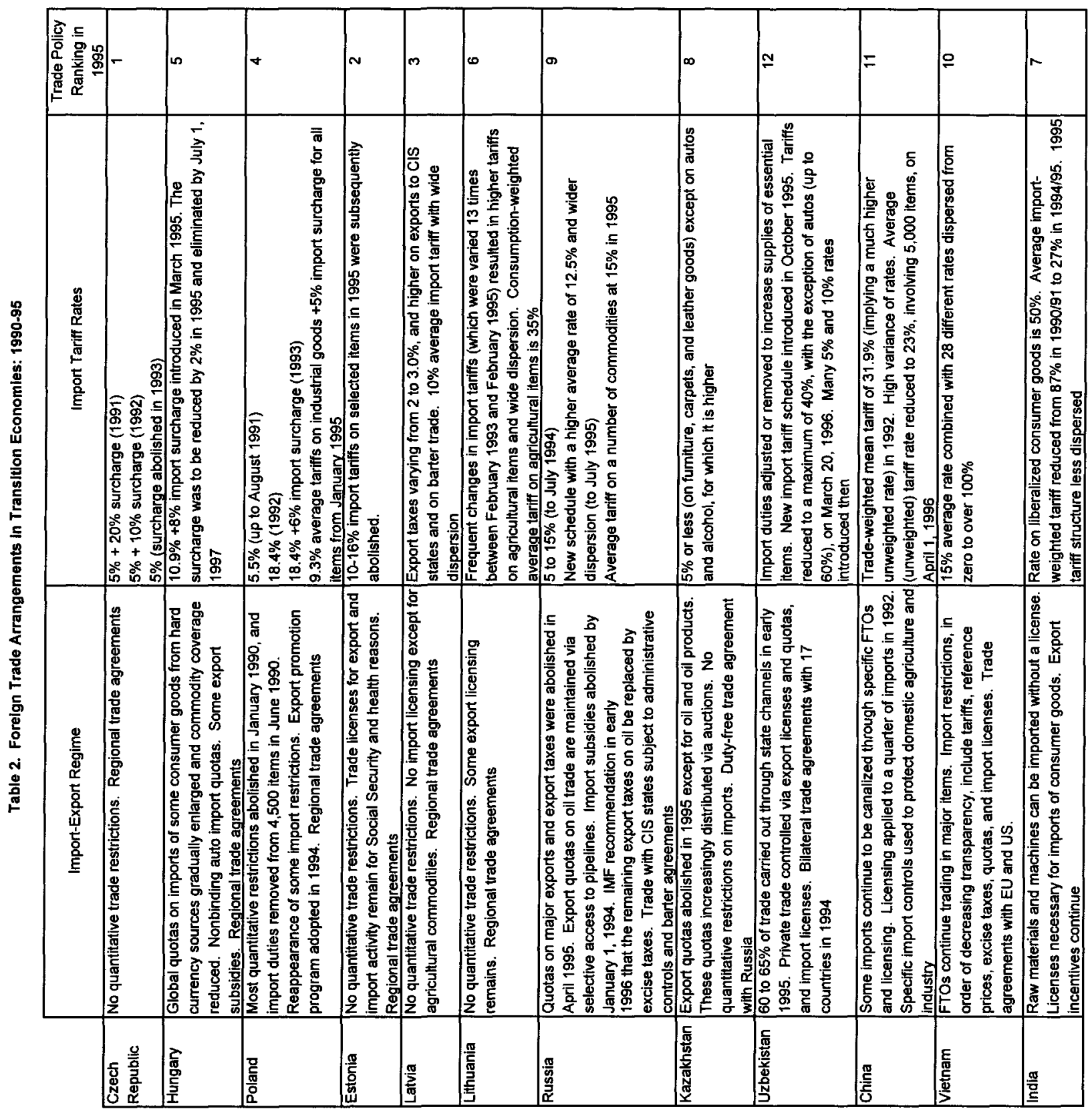

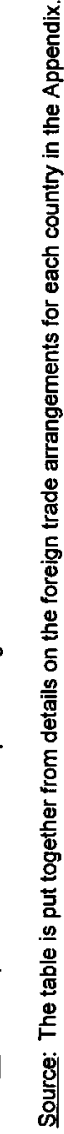




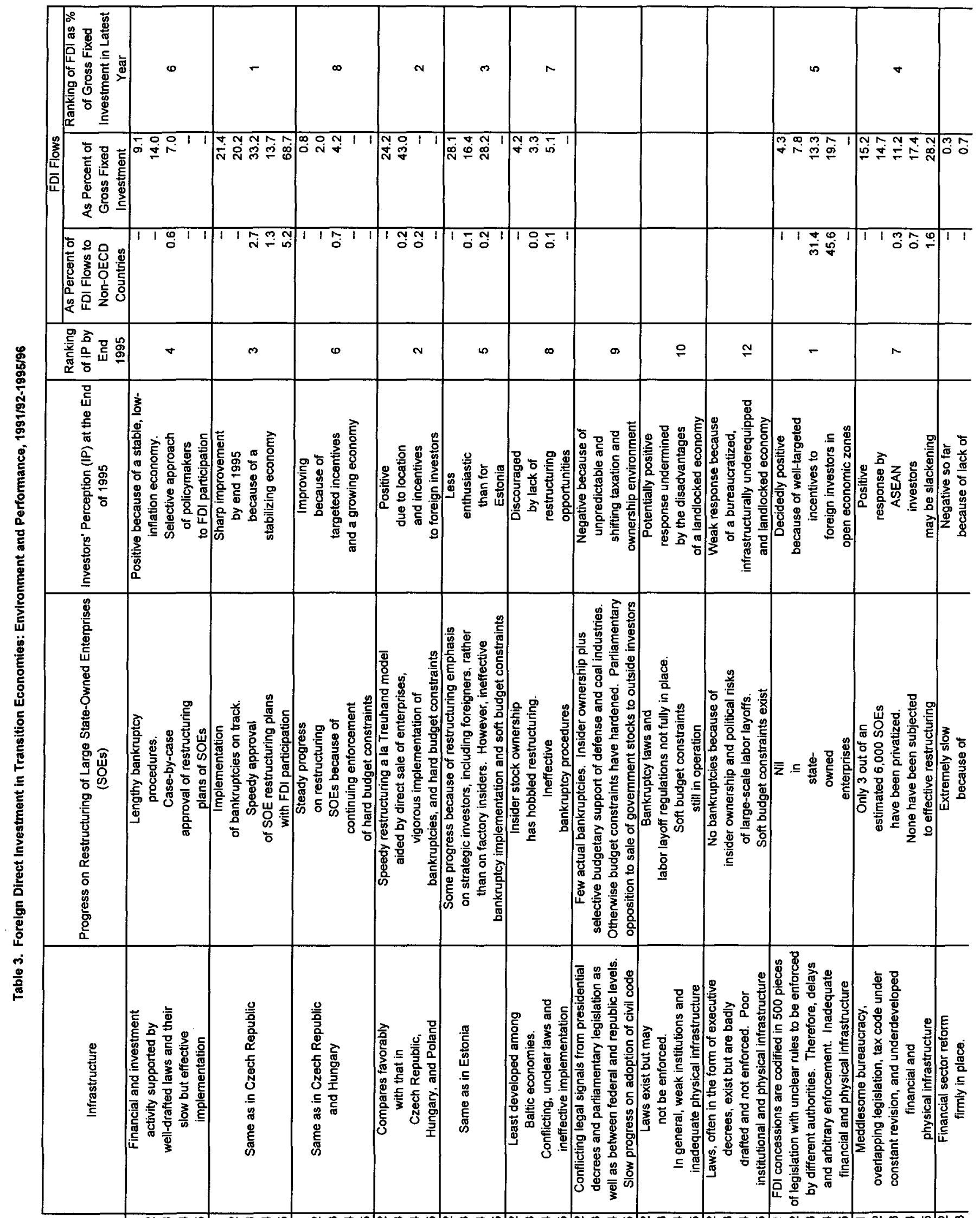

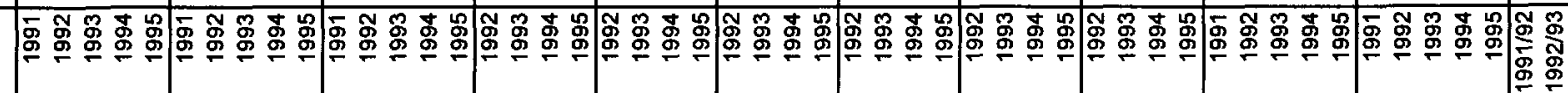

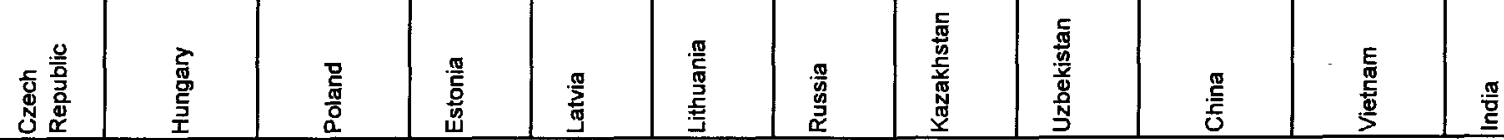




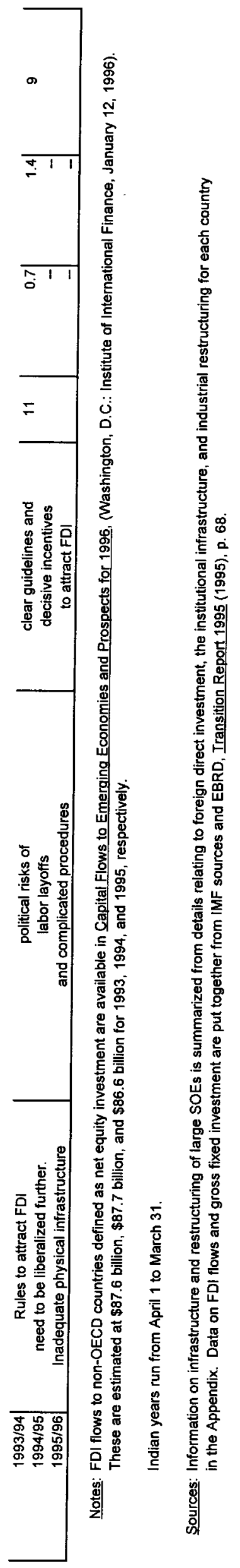


Table 4. Export Performance of Transition Economies: 1990/91-1995/96

\begin{tabular}{|c|c|c|c|c|c|}
\hline & & $\begin{array}{c}\mathrm{X}+\mathrm{M} / \mathrm{GDP} \\
\text { Index }\end{array}$ & $\begin{array}{c}\mathrm{X} \text { to OECD/ } \\
\text { Total } \mathrm{X} \\
(\%)\end{array}$ & $\begin{array}{c}\text { Manufactured Goods } \mathrm{X} \text { to OECD/ } \\
\mathrm{X} \text { to OECD } \\
(\%) \\
\end{array}$ & $\begin{array}{l}\text { Export } \\
\text { Performance } \\
\text { Ranking }\end{array}$ \\
\hline & 1991 & 1.00 & 55.14 & 59.75 & \\
\hline & 1992 & 1.29 & 67.50 & 65.98 & \\
\hline Czech & 1993 & 1.39 & 55.48 & 68.84 & 4 \\
\hline \multirow{2}{*}{ Republic } & 1994 & -1 & 60.23 & 71.50 & \\
\hline & 1995 & - & & & \\
\hline \multirow{6}{*}{ Hungary } & 1990 & 1.00 & 53.87 & 52.26 & \\
\hline & 1991 & 1.56 & 67.29 & 57.00 & \\
\hline & 1992 & 1.45 & 70.56 & 63.98 & 3 \\
\hline & 1993 & 1.42 & 67.06 & 62.60 & \\
\hline & 1994 & 1.61 & 71.19 & 66.63 & \\
\hline & 1995 & 1.72 & - & - & \\
\hline \multirow{6}{*}{ Poland } & 1990 & 1.00 & 66.05 & 48.85 & \\
\hline & 1991 & 1.11 & 74.08 & 50.44 & \\
\hline & 1992 & 0.97 & 72.64 & 59.46 & 2 \\
\hline & 1993 & 1.08 & 75.80 & 68.61 & \\
\hline & 1994 & 1.17 & 75.85 & 71.64 & \\
\hline & 1995 & - & -- & - & \\
\hline \multirow{5}{*}{ Estonia } & 1991 & - & & - & \\
\hline & 1992 & 1.00 & 52.91 & 31.70 & \\
\hline & 1993 & 1.22 & 57.93 & 38.73 & \\
\hline & 1994 & 1.24 & 55.05 & 42.20 & \\
\hline & 1995 & -1 & - & - & \\
\hline \multirow{5}{*}{ Latvia } & 1991 & -1 & - & - & \\
\hline & 1992 & 1.00 & - & - & \\
\hline & 1993 & 0.72 & - & -1 & \\
\hline & 1994 & 0.51 & 43.16 & 49.60 & \\
\hline & 1995 & - & & - & \\
\hline \multirow{5}{*}{ Lithuania } & 1991 & - & & - & \\
\hline & 1992 & 1.00 & 23.04 & 28.94 & \\
\hline & 1993 & 1.09 & - & - & \\
\hline & 1994 & 0.58 & 32.03 & 45.56 & \\
\hline & 1995 & -1 & & -1 & \\
\hline \multirow{6}{*}{ Russia } & 1990 & 7.00 & 35.96 & 17.60 & \\
\hline & 1991 & 0.73 & 56.50 & 10.20 & \\
\hline & 1992 & 3.06 & 58.61 & 9.30 & \\
\hline & 1993 & 1.90 & 59.59 & 6.80 & \\
\hline & 1994 & 1.41 & 52.85 & 9.30 & \\
\hline & 1995 & --1 & 49.84 & 11.10 & \\
\hline \multirow{6}{*}{ Kazakhstan } & 1990 & 1.00 & 5.00 & (average 1989-90) 33.50 & \\
\hline & 1991 & 1.73 & 5.30 & - & \\
\hline & 1992 & 3.81 & 17.00 & -1 & \\
\hline & 1993 & 2.03 & 16.50 & - & \\
\hline & 1994 & 1.89 & 23.50 & 4.50 & \\
\hline & 1995 & - & 27.77 & 4.80 & \\
\hline \multirow{5}{*}{ Uzbekistan } & 1991 & - & -1 & -1 & \\
\hline & 1992 & - & - & - & \\
\hline & 1993 & - & & - & \\
\hline & 1994 & 1.00 & 20.33 & 8.30 & \\
\hline & 1995 & 0.68 & 20.43 & 2.60 & \\
\hline \multirow{7}{*}{ China } & 1990 & 1.00 & 34.78 & 53.61 & \\
\hline & 1991 & 1.14 & 34.81 & 59.68 & \\
\hline & 1992 & 1.17 & 35.57 & 65.15 & 1 \\
\hline & 1993 & 1.16 & 52.45 & 77.89 & \\
\hline & 1994 & 1.50 & 51.60 & 79.33 & \\
\hline & 1995 & - & -1 & - & \\
\hline & 1991 & 1.00 & -1 & - & \\
\hline
\end{tabular}




\begin{tabular}{|c|c|c|c|c|c|}
\hline Vietn & $\begin{array}{l}1992 \\
1993 \\
1994 \\
1995\end{array}$ & $\begin{array}{l}1.18 \\
1.12 \\
1.38 \\
1.58\end{array}$ & 66.00 & $\begin{array}{l}- \\
- \\
-\end{array}$ & \\
\hline Apr. & $\operatorname{ar.} 31$ '91 & 1.00 & 56.70 & 73.66 & \\
\hline & 1991/92 & 1.08 & 58.13 & 72.10 & \\
\hline \multirow[t]{4}{*}{ India } & $1992 / 93$ & 1.11 & 60.83 & 74.16 & 5 \\
\hline & $1993 / 94$ & 1.42 & 57.20 & 73.33 & \\
\hline & $1994 / 95$ & 1.30 & 59.03 & 74.10 & \\
\hline & $1995 / 96$ & - & & & \\
\hline
\end{tabular}

Notes: Manufactured goods exports include SITC categories 6 (manufactured goods, classified chiefly by material), 7 (machinery and transport equipment), and 8 (miscellaneous manufactured articles).

Export performance ranking is based on the average annual rate of growth (average of the annual growth rates) of (manufactured goods $X$ to $O E C D / X$ to $O E C D$ ) ratios. These rates are: China, $10.5 \%$; Poland, $10.25 \%$; Hungary, 6.4\%; the Czech Republic, 6.2\%; and India, $0.2 \%$. The remaining countries are not ranked.

$(X+M)$ in $(X+M / G D P)$ ratios for Russia, Kazakhstan, and Uzbekistan represent FSU and non-FSU exports and imports. FSU values are converted into dollars via the average annual exchange rate.

( $X$ to OECD/Total $X$ ) ratios for Russia, Kazakhstan and Uzbekistan represent the relative share of exports to non-FSU industrial countries in total non-FSU exports (which include shipments to developing countries and non-FSU transition economies as well).

(manufactured goods $X$ to $O E C D / X$ to $O E C D$ ) ratios for Russia, Kazakhstan and Uzbekistan represent relative share of manufactured goods exports to non-FSU industrial countries in total non-FSU exports defined above.

Sources: $(X+M / G D P)$ ratios are computed from trade data and GDP estimates in IMF reports;

$(X$ to OECD/Total $X$ ) and (Manufactured Goods $X$ to OECD/ $X$ to OECD) ratios for the Czech Republic, Hungary, Poland, Latvia, Lithuania, China, and India are computed from information in World Trade Organization sources. All ratios for Russia, Kazakhstan, and Uzbekistan were supplied by the World Bank. 
Table 5. Reform Speed and Transition Record: $1991-95$

Country Ranking in Terms of:

\begin{tabular}{|c|c|c|c|c|c|c|c|c|c|}
\hline \multirow[b]{2}{*}{ Speed of Reform } & \multirow[b]{2}{*}{$\begin{array}{l}\text { GDP Growth } \\
\text { Rate in } 1995\end{array}$} & \multirow[b]{2}{*}{$\begin{array}{c}\text { Unemploy } \\
\text { ment Rate } \\
\text { in } 1995\end{array}$} & \multicolumn{3}{|c|}{ Inflation Rate: } & \multirow[b]{2}{*}{$\begin{array}{c}\text { Foreign } \\
\text { Exchange } \\
\text { Regime in } \\
1995\end{array}$} & \multirow[b]{2}{*}{$\begin{array}{c}\text { Trade } \\
\text { Policy } \\
\text { Regime in } \\
1995\end{array}$} & \multirow[b]{2}{*}{$\begin{array}{c}\text { Foreign } \\
\text { Investor } \\
\text { Perception } \\
\text { by end } \\
1995\end{array}$} & \multirow[b]{2}{*}{$\begin{array}{l}\text { FDI as Share } \\
\text { in Gross } \\
\text { Fixed } \\
\text { Investment in } \\
\text { Latest Year }\end{array}$} \\
\hline & & & in 1995 & $\begin{array}{l}\text { Decline } \\
\text { over } \\
\text { Reform } \\
\text { Period }\end{array}$ & $\begin{array}{c}\text { Decline } \\
\text { from Peak } \\
\text { to Next } \\
\text { Year }\end{array}$ & & & & \\
\hline $\begin{array}{l}\text { I. High Speed } \\
\text { 1. Poland } \\
\text { 2. Estonia } \\
\text { 3. Latvia } \\
\text { 4. Lithuania } \\
\text { 5. Czech } \\
\text { Republic } \\
\text { 6. Vietnam } \\
\text { II. Medium Speed } \\
\text { 7. Hungary } \\
\text { 8. India } \\
\text { 9. China } \\
\text { III. Low Speed } \\
\text { 10. Russia } \\
\text { 11. Kazakhstan } \\
\text { 12. Uzbekistan }\end{array}$ & $\begin{array}{l}3 \\
4 \\
9 \\
7 \\
6 \\
\\
2\end{array}$ & $\begin{array}{l}9 \\
6 \\
3 \\
4 \\
1\end{array}$ & $\begin{array}{l}5 \\
3 \\
4 \\
7 \\
1 \\
2\end{array}$ & $\begin{array}{l}4 \\
1 \\
2 \\
3 \\
8 \\
5\end{array}$ & $\begin{array}{l}4 \\
1 \\
3 \\
7 \\
5 \\
6\end{array}$ & $\begin{array}{l}7 \\
2 \\
3 \\
4 \\
1 \\
6\end{array}$ & $\begin{array}{c}4 \\
2 \\
3 \\
6 \\
1 \\
10\end{array}$ & $\begin{array}{l}6 \\
2 \\
5 \\
8 \\
4 \\
7\end{array}$ & $\begin{array}{l}8 \\
2 \\
3 \\
7 \\
6\end{array}$ \\
\hline $\begin{array}{l}\text { Correlation } \\
\text { coefficient with } \\
\text { reform speed } \\
\text { ranking }\end{array}$ & $\begin{array}{c}0.48(12) \\
0.66^{*} \\
(11, \text { without } \\
\text { China) } \\
0.87^{*} \\
(9, \text { without } \\
\text { Asia) }\end{array}$ & $\begin{array}{c}-0.25 \\
(9, \text { without } \\
\text { Asia })\end{array}$ & $\begin{array}{l}0.62^{* *} \\
(10, \\
\text { without } \\
\text { India and } \\
\text { China) }\end{array}$ & $\begin{array}{c}0.75^{*} \\
(10, \\
\text { without } \\
\text { India and } \\
\text { China) }\end{array}$ & $\begin{array}{c}0.50 \\
(10, \text { without } \\
\text { India and } \\
\text { China) }\end{array}$ & $\begin{array}{c}0.74^{*} \\
(12)\end{array}$ & $\begin{array}{c}0.78^{\star} \\
(12)\end{array}$ & $\begin{array}{c}0.52^{* \star} \\
(12)\end{array}$ & $\begin{array}{c}0.58^{*} \\
(12)\end{array}$ \\
\hline \multicolumn{7}{|c|}{ Correlation coefficient with 1995 foreign exchange regime ranking } & $\begin{array}{l}0.69^{*} \\
(12)\end{array}$ & $\begin{array}{l}0.66^{\star} \\
(12)\end{array}$ & $\begin{array}{l}0.61^{\star} \\
(12)\end{array}$ \\
\hline \multicolumn{8}{|c|}{ Correlation coefficient with 1995 trade policy regime ranking } & $\begin{array}{l}0.46 \\
(12)\end{array}$ & $\begin{array}{l}0.48 \\
(12) \\
\end{array}$ \\
\hline \multicolumn{9}{|c|}{ Correlaticn coefficient with (1995-end) foreign investor perception ranking } & $\begin{array}{l}0.85^{*} \\
(12) \\
\end{array}$ \\
\hline
\end{tabular}

Notes: The correlation coefficients are the pairwise Spearman rank correlation coefficient estimates. The sample size is stated in parentheses under each estimate.

* These estimates are statistically significant at the 5 percent level.

*" These estimates are statistically significant at the 10 percent level.

+ These rankings are not based on any calculations. I have assumed that the Russian share of FDI in gross fixed investment in 1995 was higher than that in India, Kazakhstan, and Uzbekistan, in that order.

Rank 1 is assigned to the country with the highest 1995 GDP growth rate and FDI share in gross fixed investment (in the latest year), most liberal 1995 foreign exchange and trade policy regimes, and the most positive foreign investor perception by end 1995.

Rank 1 is assigned to the country with the lowest 1995 unemployment and inflation rates, and the sharpest decline of the inflation rate during the period and from its peak to next year.

The decline in the inflation rate for each country over the reform period is calculated from Table 1 as the proportionate difference between the highest inflation rate and the 1995 inflation rate. Inflation rate decline from peak to next year is measured from Table 1 as the proportionate drop between the highest and next year's inflation rates.

China, Vietnam, and India are omitted from the sample in estimating the correlation coefficient between reform speed ranking and 1995 unemployment rate ranking because the unemployment problem in these Asian economies is not comparable with that in the remaining countries. The former is essentially structural, whereas the latter resulted from macroeconomic stabilization and privatization measures.

India and China are omitted from the sample in estimating the correlation coefficient between reform speed ranking and the three inflation rate rankings because these two economies were not marked by the extreme initial inflation rates prevailing in the remaining countries. By contrast, Vietnam's inflation rate in 1988 was 400 percent.

Sources: Country rankings of GDP growth rate, unemployment and inflation rates, and foreign exchange regimes (all in 1995 ) are from Table 1. 1995 trade policy ranking is from Table 2. Rankings based on foreign investor perception (by end 1995) and on FDI share in gross fixed investment (in the latest year) are from Table 3. 


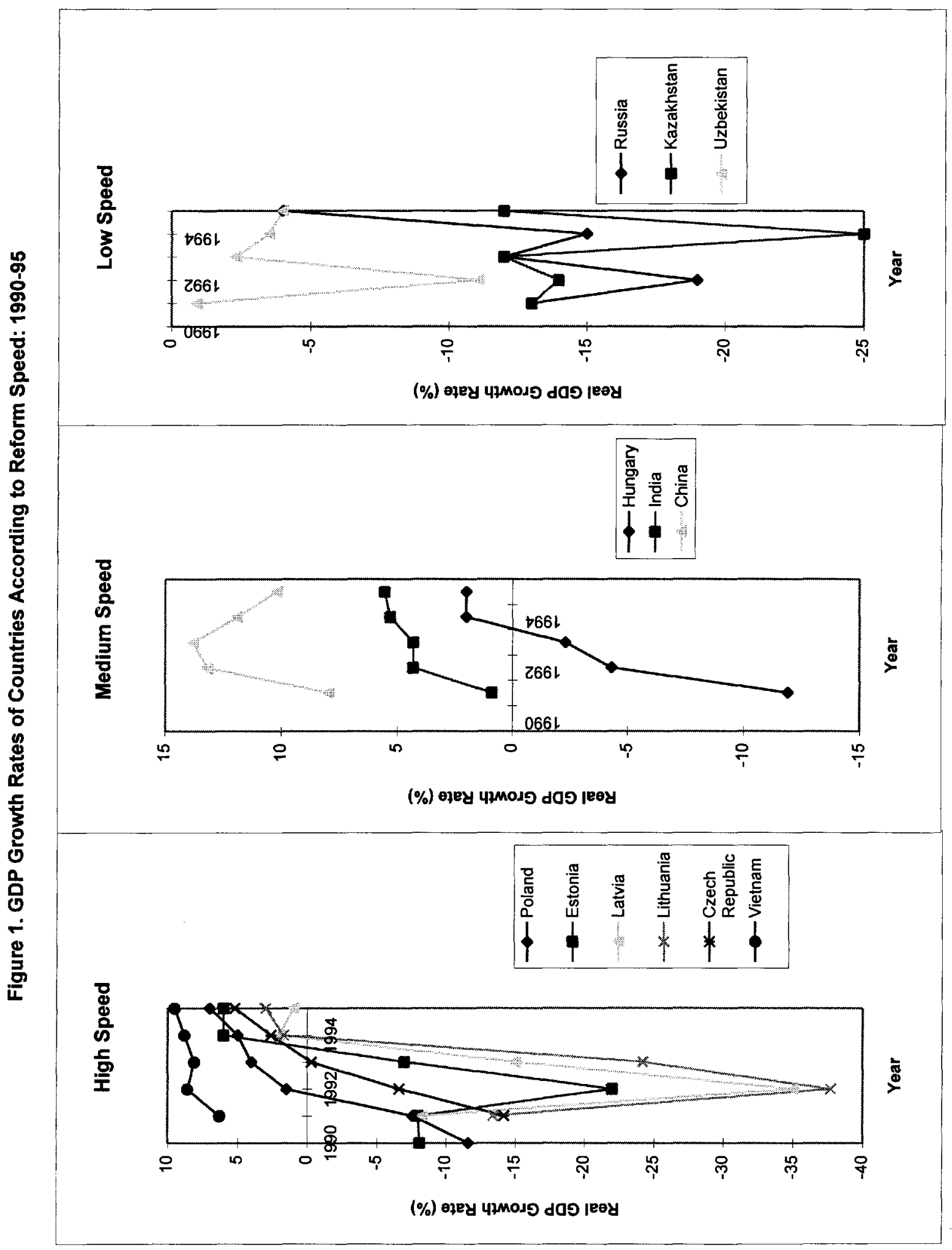


Figure 2. Inflation Rates of Countries According to Reform Speed: 1990-95

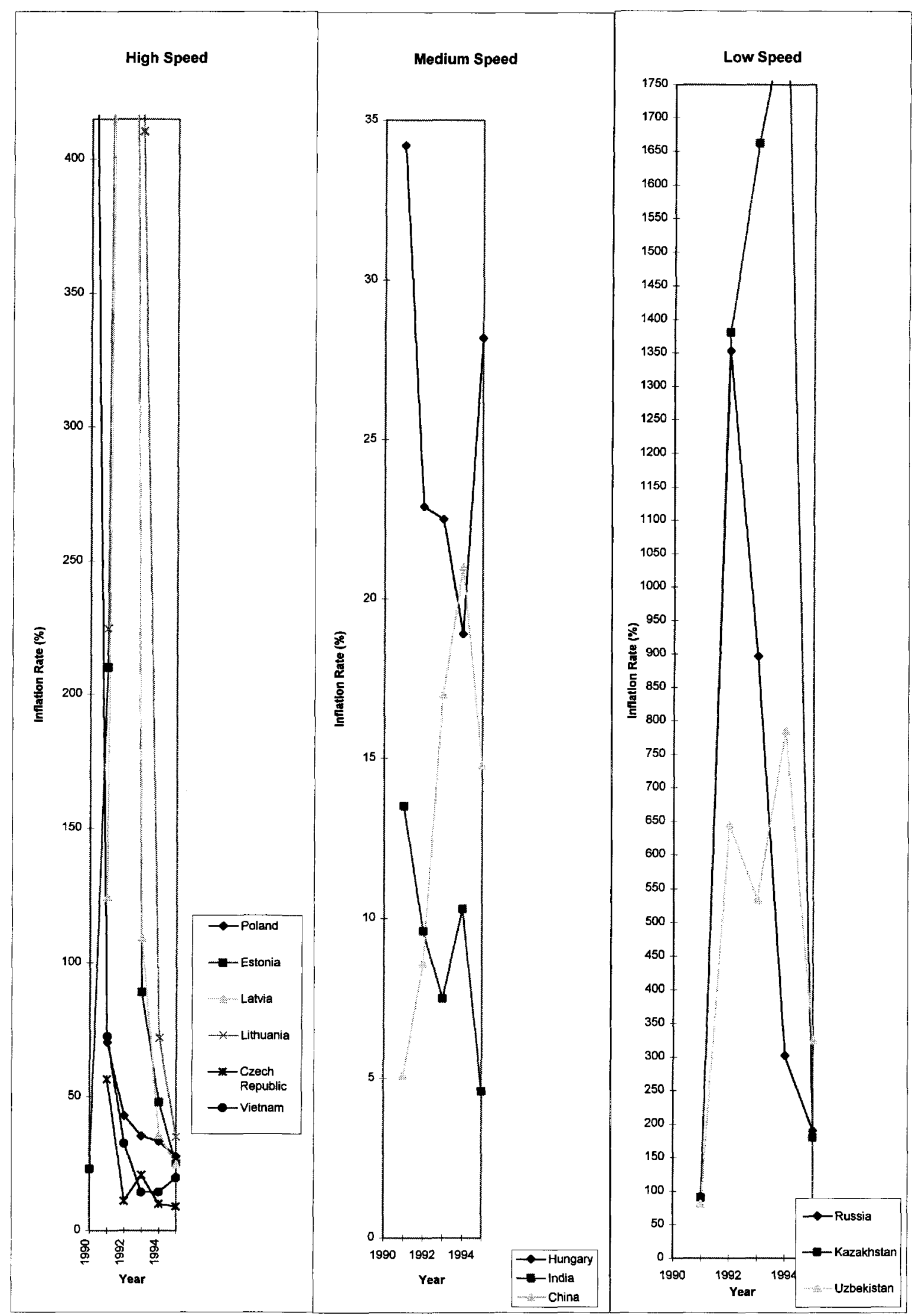

Inflation rates overshooting the upper limit of the figure:

Poland $1990=585.8$

Estonia $1992=1069$

Latvia $1992=951.2$

Lithuania $1992=1020.5$
Inflation rate overshooting the upper limit of the figure: Kazakhstan $1994=1880$

Overlapping inflation rates in the figure:

Russia $1991=92.7$

Kazakhstan $1991=90.9$

Uzbekistan $1991=82.2$

Vietnam's inflation rate in 1988 was 400 percent.

Source: Data are from Table 1. 
Figure 3. Country Ranking According to Reform Speed and 1995 GDP Growth Rates

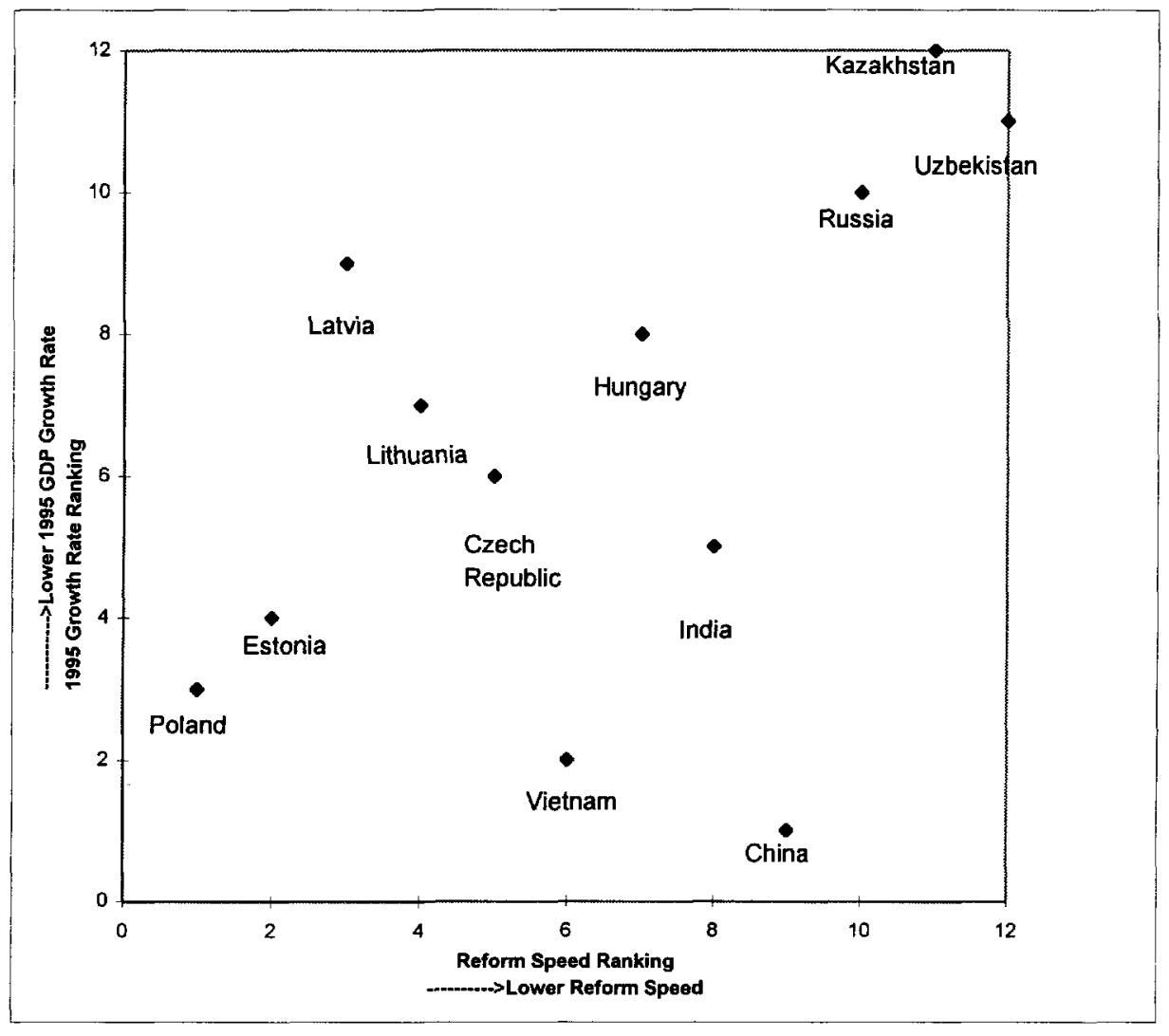

Note: The rank-correlation coefficient between the two rankings with the full sample of twelve countries, statistically not significant, is 0.48 . When China is omitted, it rises to 0.66 and is statistically significant at the 5 percent significance level. it is 0.87 and statistically significant at the 5 percent significance level when the three Asian economies, which did not experience a transition GDP growth turnaround, are excluded.

Source: Data are from Table 5. 
Figure 4. Country Ranking According to Reform Speed and 1995 Unemployment Rates

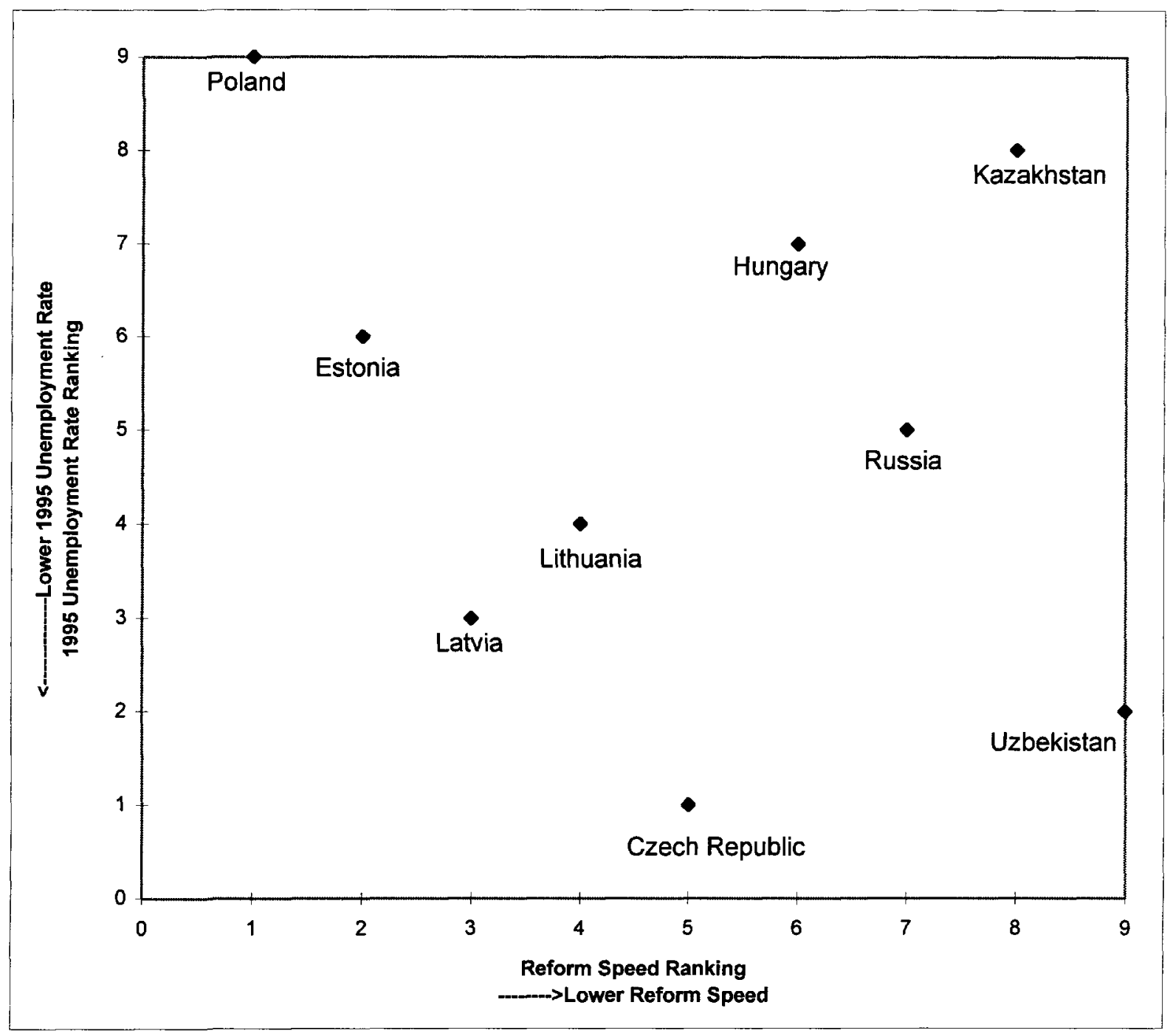

Notes: The three Asian economies -- China, Vietnam, and India - are omitted because their unemployment, which is structural, differs from that in the remaining economies, which evidently experienced labor layoffs associated with macroeconomic stabilization and privatization measures.

The rank correlation coefficient between the two rankings, statistically not significant, is -0.25 .

Source: Data are from Table 5. 
Figure 5. Country Ranking According to 1995 GDP Growth and Unemployment Rates

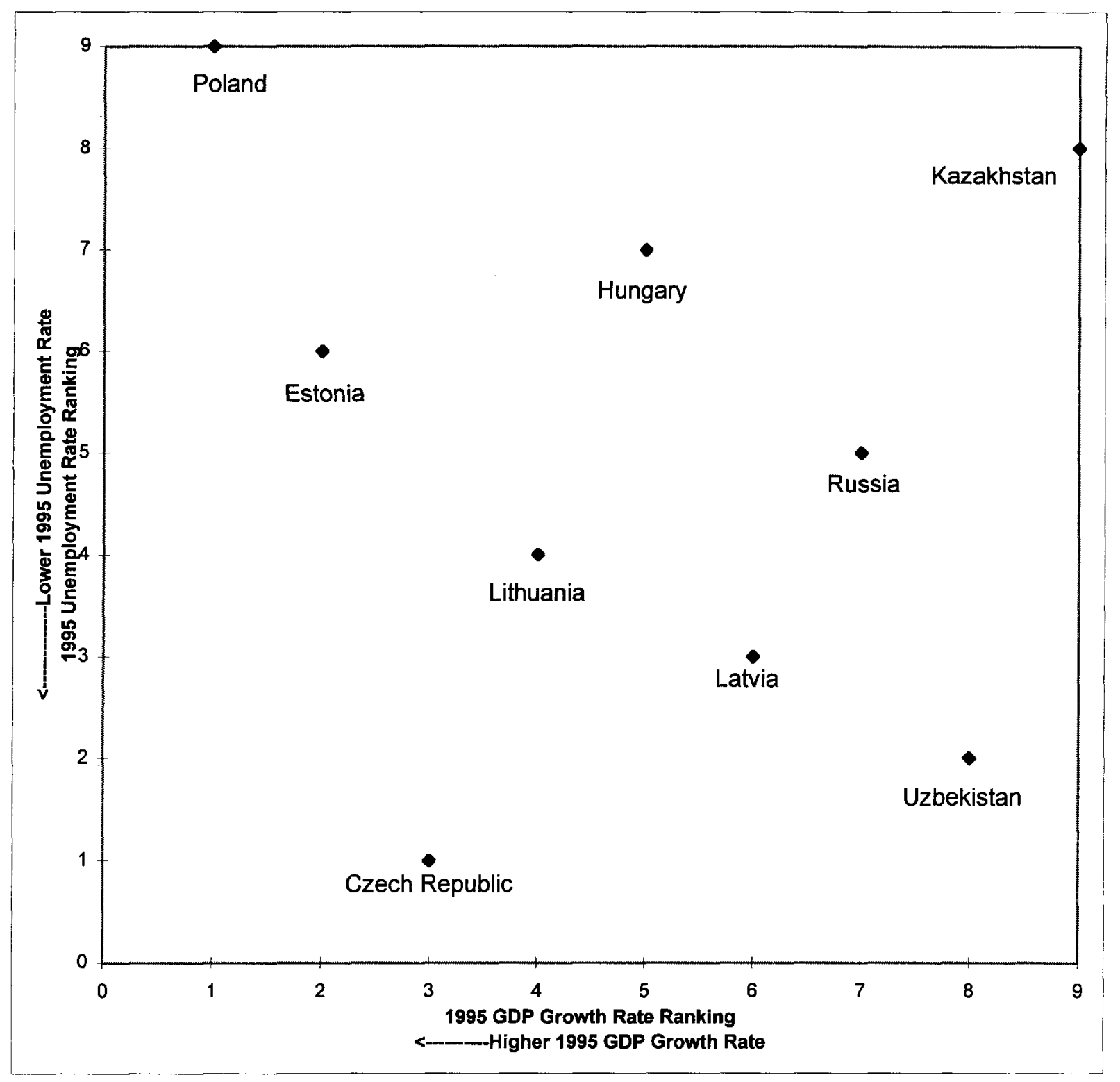

Note: The rank correlation coefficient between the two rankings, -0.15 , lacks statistical significance.

Source: Data are from Table 5. 


\section{APPENDIX}

\section{THE CZECH REPUBLIC}

\section{Main Features of the Transition Reforms and their Outcomes}

Wholesale and retail prices were liberalized in January 1991. By mid-1991, goods that made up 90 percent of GDP value were freed. It is estimated that 5 percent of prices are currently regulated.

An elaborate system of wage tariffs (which allowed some flexibility) was retained in order to forestall an inflationary price-wage spiral. Wage controls were enforced via taxes levied on excessive wage increases. Real wages at the end of 1992 were lower than at the start of 1990. These wage controls were removed in July 1995.

The consolidated budget of the government showed a surplus in 1991 and a small deficit in 1992.

A restrictive monetary policy in 1991 was implemented via ad hoc and quantitative measures. It was followed by the adoption of indirect market instruments, and eased in 1992 leading to a real growth in M2. Interest rates were completely liberalized in April 1992.

In January 1990, the commercial and non-commercial rates of the koruna were unified and the currency was made convertible for trade transactions a year later. At the same time, the koruna was devalued in late 1990 and early 1991.

As a result of the restrictive fiscal and monetary measures, real GDP declined by 14.2 percent in 1991 and 6.6 percent in 1992. Exports and imports declined (in real terms) in 1991 with the real trade balance improving sharply in 1991 by 16 percent. By 1992, real exports had risen considerably and real imports had almost recovered to 1989 levels. At the same time, the Czechoslovak economy (while maintaining a trade surplus under a liberalized trade regime) had oriented its exports to the West.

By the end of 1992, the Czechoslovak economy was showing signs of revival with GDP growing in the last two quarters, direct foreign investment increasing, and the balance of payments in good shape. However, the aggregate numbers masked differences between the two republics. In Slovakia, unemployment at 12 percent was at least three times higher than in the Czech Republic. The Slovak budget was under strain despite subsidization by the Czech Republic. Social and political pressures led to the partitioning of Czechoslovakia into two independent states at the beginning of 1993 . The result was a substantial decline in bilateral trade.

The separation freed the Czech Republic to follow more conveniently the macroeconomic policies that had been the hallmark of 1991 and 1992.

Real GDP decline of 14.2 percent in 1991, 6.6 percent in 1992 and 0.3 percent in 1993 was reversed in 1994 with a growth rate of 2.6 percent and a projected growth rate of 4 percent in 1995 . The low unemployment rate, averaging 3 percent of the labor force since the beginning of the reform, continued at that level in 1995. The inflation rate measured in consumer price index had declined from 56.5 percent in 1991 to 20.8 percent in 1993 and down to 10 percent in 1994 and 9.1 percent in 1995. The 1996 budget is expected to record a small surplus (around 1 percent of GDP) as in 1994 and 1995. The current account balance went into deficit, estimated at 4.2 percent of GDP in 1995 (following small surpluses in 1993 and 1994) as a result of accelerating growth.

\section{The Trade Regime}

The institutional changes involved the abolition of state monopoly of foreign trade starting in 1991.

There are no quantitative trade restrictions. The import tariff rate is low at 5 percent. (The surcharge of 20 percent was gradually abolished in 1993.)

Trade with the smaller members of the Council of Mutual Economic Assistance (CMEA), which was dissolved in September 1991, was put on a hard currency basis using world market prices. Among measures to sustain trade with members of the ex-CMEA were the formation of the Central European Free Trade Agreement (CEFTA) with Poland and Hungary in December 1992, and the search for barter agreements with the post-Soviet states in order to continue exporting traditional manufactures and importing raw materials.

Association Agreements (which became effective in March 1992) were also signed with the European Union for mutual lowering of tariffs, and subsequently with the European Free Trade Area (EFTA).

The Czech Republic became a member of the WTO in December 1994. The first post-Communist state, it signed an agreement to join the OECD in November 1995. 
3. The Foreign Exchange Regime

Since May 1993, the Czech koruna has been pegged to a basket of two currencies with a weight of 65 percent for the deutschemark and 35 percent for the dollar. The koruna's market value is determined in daily auctions between the Czech National Bank (CNB) and the commercial banks. The currency, which fluctuated within a 0.5 percent band around the nominal peg in 1995 , was allowed a wider band of +7.5 percent from February 1996. As a result, the CNB was ready to use the full width of the band to increase uncertainty in the exchange rate to discourage speculative inflow of capital.

\section{Currency Covertibility}

"The new Foreign Exchange Law, effective on 1 October 1995, provides full current account convertibility and partial capital account convertibility. According to the draft law, Czechs will have the right to convert crowns into hard currency to buy foreign real estate, and Czech companies will have the right to buy foreign currency to make investments abroad. On the side of capital inflows the main restriction will apply to purchase of real estate in the Czech Republic by nonresidents." (European Bank for Reconstruction and Development (EBRD), Transition Report 1995, p. 40).

\section{Direct Foreign Investment}

Foreign investors face no limits on equity participation. Nonresidents can fully repatriate their capital and capital gains after paying taxes. Foreign residents in EU countries can invest in the Czech Republic without a license although they need to report their corporate activities.

The sharp decline in DFI in 1993 was offset by higher portfolio investment. The offer of equity in telecommunications and energy in 1995 to foreign investors was expected to stimulate DFI flows. The strong balance of payments and a strong koruna also attract foreign investors. However, the authorities had moved to a selective approach combining incentives to domestic industry with positive signals to foreigners to invest in key sectors on a caseby-case basis.

Cumulative DFI from 1990 to end of 1995 amounted to $\$ 5.8$ billion. Japan and other Asian investors, such as South Korea and Taiwan, have been slow to enter the emerging markets of Central and East Europe. The 1996 decision by Matsushita Electric of Japan to invest in a television plant in the Czech Republic for its Panasonic subsidiary plant marks a departure in that regard.

\section{The Institutional Infrastructure}

Laws governing investment activity are clearly drafted and properly implemented albeit with some delay.

A two-tier banking system was created in 1990. The legal framework defining the functions of the central bank and the commercial banks is currently in place. There were 50 commercial banks at the start of 1994 of which 11 were fully foreign-owned. Despite continuing attempts at strengthening the balance sheets of banks, problems of deteriorating portfolios and undercapitalization persist in small banks. Banks continue to extend loans to failing enterprises because bankruptcy procedures are not enforced energetically. Following the failure of three banks in 1994, the CNB has initiated measures to consolidate hte banking sector, restrict the granting of new licenses, and encouraged small banks to merge.

By May 1995, there were 365 invetment companies, 279 investment privatization funds, and 60 private insurance companies, a few foreign-owned.

Trading on the Czech stock exchange began in April 1993. Its activity is currently constrained by inadequate domestic capital and insufficient information about companies whose stocks are traded. After a year of trading, only 23 of the 1,000 shares were traded and share prices on the stock exchange remained highly volatile. However, by early 1995 , automated processing of recording, concluding and settling direct stock exchange trades had begun.

Standard and Poor, the U.S. debt-rating agency upgraded its rating of the Czech economy to A-stable in November 1995, the highest in the region.

\section{Industrial Restructuring}

Large state-owned enterprises (SOEs), which have been converted into joint stock companies, are being restructured on a case-by-case basis with participation by local and foreign investors. The bankruptcy procedures are 
however slow.

The surge in foreign investment rising to $\$ 2.6$ billion in 1995 compared with $\$ 862$ million in 1994 and $\$ 568$ million in 1993 resulted from a series of key restructuring deals involving sale of stakes in the Czech telecommunications and oil refining sectors.

\section{HUNGARY}

\section{Main Features of the Transition Reforms and their Outcomes}

The post-May 1990 government continued the process of price decontrol and, by the end of 1990, all prices were freed except charges for public transport and household energy use which were raised.

As a result of the fiscal measures introduced by the government, the 1990 deficit of the state budget (excluding local government activity) showed a surplus of 0.8 percent of GDP. However, the surplus had moved to a deficit of 7.7 percent in 1994, and a projected 5 percent in 1995. (This resulted from reform-related measures in the early years such as issuance of debt to finance recapitalization of commercial bank debts, suspension of tax and social security payments by bankrupt enterprises, the takeover by the budget of subsidized loans for housing from the National Savings Bank and finally, the switch to financing budget deficits by issuing securities at market interest rates from 1991; from increased expenditure from the budget on goods and services and unemployment compensations. The growth in expenditures in 1995 was dominated by a projected 56 percent increase in interest payments reflecting the cumulative burden of past deficits and the rise in interest rates.)

Monetary policy until mid-1993 was marked by lower interest rates to boost domestic demand and secure economic recovery. As the external current account balance deteriorated (from increased import demand), the policy was reversed and a tight monetary control began in 1994 and continued in 1995.

Reflecting the relaxed monetary policy and the central bank financing of the budget deficit, inflation measured by the consumer price index remained at 22.5 percent in 1993, almost the same as in 1992. It was 18.9 percent in 1994 and 28.2 percent in 1995 , substantially ahead of world inflation.

As a result, the National Bank of Hungary devalued the forint five times in 1993 and seven times in 1994, altogether by a cumulative 76.6 percent relative to its 1989 level. The unit-labor cost based real exchange rate at the end of 1994 was 20 percent higher than in 1990.

The reform measures resulted in a decline of real Hungarian GDP by 20 percent, of consumpton by 11.7 percent, and of fixed investment by 21.5 percent between 1989-1993. Unemployment measured as the ratio of registered unemployed in the economically active population had risen to 10 percent in January 1995. GDP grew (for the first time in four years) at 2 percent in 1994 and another 2 percent in 1995. However, the deficit in the state budget at 6.6 and 6.8 percent of GDP in 1993 and 1994 continued to be high; so did the external current account deficit in both years at nearly 10 percent each of GDP. The external debt (net of reserves) was a whopping $\$ 21.7$ billion at the end of 1994.

The erratic exchange rate policy, which failed to counter the devaluationary expectations and establish firmly the competitiveness of Hungarian exports, was abandoned on March 12, 1995 in favor of weekly devaluations of the forint by the Hungarian National Bank. At the same time, Finance Minister Lajos Bokros announced austerity measures aimed at stabilizing the economy and putting Hungarian public finances on a long-term, sustainable basis. As a result, 1995 budget deficit was brought down to 4.1 percent of GDP. So was the 1995 current account deficit, to 5.3 percent of GDP. These improvements were expected to continue in 1996.

\section{The Trade Regime}

There are few quantitative restrictions on export and import transactions which can be undertaken by private companies. Some consumer goods imports are subject to "global quotas" which define separate ceilings for about 20 product groups. Quantitative restrictions on farm product imports were removed in accordance with the new GATT agreement in January 1995.

While import licensing and quotas have been progressively liberalized, a number of industrial and "sensitive" products (among them textiles and agriculture) remain "substantially" protected by tariffs. The nominal average import tariff rate was 10.9 percent in 1994. "On 20 March 1995, Hungary introduced an 8 per cent import surcharge on all goods, except primary energy carriers and machinery for investment. The surcharge is to be phased out during the first half of 1997." (EBRD, Transition Report 1995, p. 44) The import tariffs on agricultural items, and export subsidies (to 
exporters of grain, meat and other items) are expected to go down and eventually disappear as a result of the Association Agreement with the European Union.

Hungary became a member of the WTO in December 1994.

\section{The Exchange Rate Regime}

The exchange rate of the forint is based on a basket of currencies. The compostion of the basket has been adjusted several times. Prior to December 9, 1991, the basket consisted of 11 currencies which were weighted to reflect the currency compostion of Hungarian foreign trade turnover. Between December 9, 1991 and August 2, 1993, the basket consisted of equal proportions of the dollar and ECU. Between August 2, 1993 and May 16, 1994, it had equal weights of the dollar and the deutschemark. Since May 16, 1994, it has carried weights of 70 percent and 30 percent respectively of ECU and the dollar. The value of the forint to the basket has been adjusted periodically based on the difference between the domestic and foreign rates of inflation.

\section{Currency Convertibility}

The interbank foreign exchange market was established on July 1, 1992 and the state monopoly of foreign exchange operation was abolished. The foreign exchange operations of commercial banks have expanded steadily since 1988. Banks can lend foreign exchange to domestic enterprises and conduct foreign exchange operations on behalf of their clients.

Registered importers can purchase foreign exchange from banks for bona fide imports of goods and most services. Export earnings must be surrendered to a licensed bank in exchange for Hungarian forints within eight days of the receipt of foreign exchange.

Hungarian enterprises and residents are generally not allowed to hold bank accounts abroad.

Resident and nonresident individuals may open foreign currency bank accounts in Hungary without declaring the source of foreign exchange.

Allowances to Hungarian tourists for foreign travel are restricted to $\$ 800$ per year. No foreign exchange is made available to students for study abroad. Equally, nonresidents must register their foreign exchange and personal assets so that they can take them out of the country.

\section{Direct Foreign Investment}

The policy of privatizing factories for cash and foreign exchange through auctions and international tenders stimulated FDI. However, the tax incentives to foreign investors since 1989 have been tied to specific criteria such as the size of investment, the sphere of activity, and the share of foreign ownership in the company operating with foreign participation. These measures were calculated to encourage foreign investment in specific production activities and promote advanced technologies.

Instead, given the poor macroeconomic performance and an unstable currency, foreign investors advanced their own agenda with deliberate caution and calculation. They concentrated on the distribution, commercial, financial, and real estate (including hotels) sectors, stepped into protected branches (such as tobacco, beer, vegetable oil and sugar), acquired a stake in the telecommunication branch, and promoted efficient use of their home production capacities by distributing their products in Hungarian markets. Barring noteworthy exceptions such as the Opel assembly plant of General Motors and the Japanese Suzuki auto factory, DFI till the end of 1994 failed to create new industrial establishments, branches or products. It went into industries and factories which operated above average technological productivity and economic efficiency.

Although their role turned out to be contrary to expectations, they provided financial resources for investment (domestic savings were abysmally low), supported the balance of payments by foreign exchange inflows, and pushed the politically-constrained Hungarian privatization process forward.

The inclusion of financial institutions (for example, banks), telecommunication and energy in the privatization program and the stabilization of the economy following the Bokros austerity measures gave a boost to DFI flows in 1995. Total DFI from 1990 to 1995 -end was estimated at $\$ 11.2$ billion.

The authorities are however careful about liberalizing portfolio flows on capital account. Occasionally, foreigners are allowed to subscribe to special issues of government bonds.

\section{The Institutional Infrastructure}


Laws relating to investment activity are properly drafted and adequately implemented albeit with delay.

The five, large state-owned banks consist of four commercial banks and the National Savings Bank (NSB). The loan portfolios of the former have continued to deteriorate. (The authorities carried out several rounds of state-financed recapitalizations in these banks in the early 1990s and have announced plans to privatize them.) By contrast, the small and medium-sized private banks, 30 in all (some of which are jointly foreign owned), offer a variety of fianancial services to viable joint ventures and domestic enterprises.

Several investment funds and insurance companies operate in Hungary. The Budapest Stock Exchange, which trades largely in treasury bills, was opened in June 1990.

\section{Industrial Restructuring}

Restructuring of large, state-owned enterprises has continued with participation by local and foreign investors. It had failed to pick up decisively until 1995 because of mixed signals from policymakers and their uncertain management of the macroeconomic situation.

\section{POLAND}

1. Main Features of the Transition Reforms and their Outcomes

The Balcerowicz Plan, which was launched on January 1, 1990, was a comprehensive, stabilization-cum-liberalization program which was aimed at reducing the rate of inflation and restoring internal equilibrium in the Polish economy.

The plan sought to impose fiscal control by balancing the budget via drastic cuts in subsidies. At the same time, the National Bank of Poland (NBP) imposed monetary discipline by fixing the discount rate (which sets a floor to the interest rate structure) slightly above the anticipated rate of inflation.

Most prices, except charges for domestic utilities, basic medicines, local housing and alcohol, were liberalized in 1990-91. The excess wage (Popiwek) tax, imposed on state enterprises in 1990, led to an average, yearly decline in real wages of 8.4 percent in the state sector from 1990 to 1993. In 1994, it was abolished and replaced by arrangements which linked enterprise wages to profitability. Since January 1995, wages are set via tripartite negotiations among government, employers and worker representatives.

The foreign exchange regime was simplified: The zloty was fixed on January 1, 1990 at the rate of 9,500 zlotys in exchange for a dollar for three months after which the rate could be adjusted if necessary. The foreign trade arrangements were liberalized: Almost all direct controls on external commercial transactions were removed. Barring a few exceptions, Polish enterprises were freed to import and export without obtaining permits.

The restrictive monetary and fiscal policy worked "too well" (till September 1990). The 1990 state budget was in surplus at 0.7 percent of GDP. The volume of credit (in real terms) declined. Real GDP fell by 11.6 percent and unemployment climbed from 0.1 percent in 1989 to 6.1 percent by 1990-end. Subsequently, real GDP recovered from a further decline of 7.6 percent in 1991 to a positive growth of 5 percent in 1994 and 7 percent in 1995 . However, the consumer price index was running at 33.3 percent in 1994 (slightly lower at 27.8 percent in 1995), the unemployment rate had climbed to 16 percent by the end of 1994, and the state budget was in the red to the tune of 3 percent of GDP in 1994 (about the same at 2.8 percent of GDP in 1995).

In the meantime, the negotiations with GATT, the European Union and with EFTA, and the formation of the Visegard trading bloc took on a "strategic" character. Poland sought to obtain better access to foreign markets. It was willing, albeit reluctantly, to reduce its trade barriers in exchange for concessions.

\section{The Trade Regime}

Poland abolished the state monopoly and administered management of foreign trade in 1990. Most nontariff restrictions were eliminated in January 1990 and tariffs became the main policy instrument. Import duties were removed from 4,500 imported items in June 1990 and the average tariff rate was set at 5.5 percent.

However, the mid-1991 to mid-1993 period was marked by a relative trade stagnation (brought about exogenously by the West European economic slump) and by a return to protectionism. Fiscal stringency also tilted the scale toward higher import tariffs. Quantitative export restrictions also reappeared. The import duty rate was raised to 18.4 percent in August 1991 and was followed by an across-the-board 6 percent import surcharge in December 1992. The need to support the balance of payments and the budget prompted these decisions. The authorities introduced a 
more protective trade regime in July 1993: They revised the tariff structure, lowered duties on raw materials and semi-finished products, and raised rates on finished items. They adopted an export promotion program which they expected to carry out in 1994.

"In January 1995, the average tariff on industrial goods was reduced to 9.3 per cent and the import surcharge was reduced to 5 per cent. In May 1995, quantitative restrictions on agricultural imports were converted into tariffs in line with GATT Uruguay Round. In July 1995, Poland became a member of the WTO." (EBRD, Transition Report 1995).

In December 1991, the European Union signed the Association Agreement with Poland (Hungary and former Czechoslovakia) and provided for immediate and progressive trade liberalization which was asymmetric. The EU promised to liberalize trade over five years in contrast to Poland's promise to reciprocate over seven years. As a result, most tariffs and all quantitative restrictions imposed by the EU on industrial goods imports (except on automobiles) were eliminated. However, trade in textiles, coal and steel, and in agricultural products is covered by special protocols. The Agreement also permits protectionist measures in infant industries, industries undergoing restructuring and facing social problems. It allows anti-dumping actions in accordance with GATT rules.

Poland signed similar agreements with EFTA and CEFTA in December 1992. The agreement with EFTA is more liberal than that with the EU. Tariffs and quotas are eliminated for all industrial goods (except for textiles and steel). In June 1993, the EU improved market access even further by reducing import duties.

\section{The Exchange Rate Regime}

The zloty was unified in January 1990 for current account transactions at the rate of 9,500 zlotys exchanging for a dollar. The exchange rate arrangement was changed on May 17, 1991 from the dollar peg to a peg which included the European currencies in the basket, and the zloty was devalued by 14.4 percent against this basket.

This fixed exchange rate regime was replaced by a pre-announced crawling peg on October 16, 1991. The rate of crawl at 1.8 percent per month was set lower than the differential between Polish inflation and the average inflation in the countries whose currencies were included in the basket. The zloty was devalued by about 11 percent against the basket on February 25, 1992. It was further devalued by 7.4 percent on August 27, 1993 and the rate of crawl was reduced from 1.8 percent to 1.6 percent per month. Since May 1995, the zloty fluctuates within a band of 7 percentage points around the central rate which is devalued at 1.2 percent per month.

\section{Currency Convertibility}

Foreign currency is freely available at the going rate for all current account payments. Citizens are free to buy and sell foreign exchange on the free market. The conversion of export proceeds into zlotys at the official rate was obligatory till the end of 1995. Nor were enterprises and individuals free to hold foreign exchange abroad.

In early 1996 Poland began moving toward full convertibility in view of its forthcoming membership in the OECD.

\section{Direct Foreign Investment}

The hesitant privatization program, the large foreign debt, and the delays in normalizing relations with commercial bank creditors discouraged foreign investors who feared increased taxation for servicing the debt. DFI is expected to accelerate in Poland as privatization picks up speed. Foreign investors are attracted to Poland because of cheap labor cost, substantial domestic demand, and Poland's proximity to the potentially large markets of the former Soviet Union.

The bulk of investment ( $\$ 4.3$ billion through 1994) is in joint ventures because Polish legislation treats such investment favorably. The new 1991 legislation abolished registration of foreign investors (except in priority sectors), simplified taxation and repatriation of investors' profits, lifted limits on profit transfers abroad, allowed repatriation of capital invested in joint ventures and in shares of Polish companies, gave tax benefits to investors in new joint ventures depending on the size of their investment and its location in areas with high unemployment.

\section{The Institutional Infrastructure}

As in the Czech Republic and Hungary, investment activity is supported by well-drafted laws and their slow but effective implementation.

Nine state-owned commercial banks and four specialized banks accounted for three-quarters of total banking 
sector assets in 1994. (Two of the nine banks have been privatized.) The Law on Financial Restructuring of Enterprises and Banks of March 1993 announced plans to recapitalize banks, restructure their loan portfolios, and deal with the bad debts of state enterprises to commercial banks.

Private commercial banks, 85 in 1993, are generally undercapitalized and at a competitive disadvantage vis-a-vis publicly-owned banks. Most of them are owned by inexperienced private entrepreneurs and investors. Some banks have foreign capital and foreign banks have opened branches in Poland. However, foreign banks generally approach Poland with caution.

The Warsaw Stock Exchange reopened in July 1991 after being closed for over fifty years. However, shares of a small number of companies are quoted on the exchange, and the stock market does not represent an important source for raising new capital. The absence of intermediaries which can prepare new issues hobbles the process. Foreigners are free to participate on the stock exchange and can repatriate their profits freely. Despite a variety of problems, the Warsaw Stock Exchange is a bustling arena of stock market activity.

\section{Industrial Restructuring}

The continuing enforcement of hard budget constraints has contributed to across-the-board progress on the restructuring of large, state-owned enterprises.

\section{ESTONIA}

1. Main Features of the Transition Reforms and their Outcomes

Soviet hidden inflation was cracked open by Estonia in the winter of 1990 when the Estonian administration liquidated most wage controls. Prices were subsequently liberalized in October 1990 via the removal of budget subsidies on food purchases by consumers. As a result, average annual consumer prices in 1991 rose by 210 percent. Estonia's price liberalization created shortages in the Baltic neighbors. Subsequently, Russian price decontrol in January 1992 (and the higher cost of energy imports from Russia) pushed inflation further in all the Baltic states. The continuing price rise was restrained by the shortage of cash resulting from the announced blockade of cash by the Russian cental bank.

Estonian policymakers stepped out of the ruble zone by introducing a new currency and requiring the immediate exchange of all rubles for the kroon (EEK). The kroon was pegged to the deutschemark on the currency board principle on the basis of the initial reserves of gold (which was frozen in Western banks in 1940 and returned to Estonia in 1992) and the demand-supply situation of foreign currency at $1 \mathrm{DM}=8 \mathrm{EEK}$. The fixed exchange rate of the kroon, which is fully convertible, is supported by central bank intervention.

Currently utility charges and housing rents continue to be regulated. Private sector wages are negotiated but state sector wages are occasionally controlled to contain wage inflation.

Export and import trade restrictions were removed in 1992. Trade licenses for export and import activity remain for social security and health reasons.

The negative impact of the measures to secure an independent, stable currency had tapered off by 1995 . The growth rate of real GDP in 1994 and 1995, at annual 6 percent was in sharp contrast to its decline of 22 percent in 1992 and 7 percent in 1993. Inflation measured in consumer prices had declined from 1,069 percent in 1992 to 89 percent in 1993 and 25 percent in 1995 . However, the unemployment rate stood at 8.1 percent in 1994, up from 4.8 percent in 1992. The budget was balanced in 1994, but the current account deficit was 6.4 percent of GDP.

The geographical reorientation of Estonia's foreign trade was dramatic and fast: The share of Estonian exports to the West rose to 40.9 percent in the first quarter of 1992 from 5.1 percent in 1991 . However, the commodity structure had not changed much. Estonia continues to export traditional consumer goods and import raw materials and machinery.

\section{The Trade Regime}

Import quotas and licensing requirements (except for products which were considered essential for national defense, health and safety), and quantitative restrictions on exports were removed when reforms began. Import tariffs (including a 16 percent tariff on furs and fur products and a 10 percent tariff on cars, motor cycles, bicycles and recreational boats), which were in force in 1995, were subsequently abolished. Export tariffs apply to articles of cultural value.

The Free Trade Agreement with the European Union, which became effective on January 1, 1995, freed trade in manufactured items and retained quotas on Estonian exports of agricultural items to the European market. Moreover, 
the Association Agreement with the EU is expected to promote trade in services, labor mobility and creation of subsidiaries by companies in each other's territory.

\section{The Exchange Rate Regime}

The Estonian kroon is pegged to the deutschemark at the rate of 1 deutschemark exchanging for 8 kroons. Therefore, the Bank of Estonia guarantees the conversion of kroon currency notes and bank deposits in the central bank into deutschemarks and vice versa.

\section{Currency Convertibility}

The kroon is convertible for current and capital account transactions. Estonian citizens can open foreign currency accounts in domestic and foreign banks. There are no requirements to surrender export earnings.

\section{Direct Foreign Investment}

Estonian policymakers have assiduously sought DFI by enacting liberal legislation (The 1991 law gave higher tax advantages to foreign investors which were removed in 1994) and by implementing a speedy privatization program in which foreigners are encouraged to participate. A stable currency, low labor costs, absence of capital account controls and historical ties with Western Europe, Finland and Russia have contributed to substantial DFI flows which amounted to $\$ 253$ million in 1994 .

\section{The Institutional Infrastructure}

The legal and financial infrastructure has improved steadily and compares favorably with that in the Czech Republic, Hungary and Poland.

Throughout 1994, the Bank of Estonia was busy drafting and seeking parliamentary approval for legislation to strengthen the commercial banks and bringing the regulatory framework in line with that in the European Union by the year 2000. The regulations specified minimum capital requirements for banks, adequate provisions for problem loans, and strict classification of bank assets. The central bank has firmed up banking supervision and monitoring with technical assistance from the Nordic countries.

The Tallin stock exchange is scheduled to start operating in 1996. In the meantime, enterprise, bank and investment fund stocks are traded over-the-counter at the computerized depository which was opened in September 1994.

\section{Industrial Restructuring}

Large enterprises (except those in the energy, transport and telecommunication sectors) have been restructured according to the East German Treuhand model via direct sale to domestic and foreign investors. Bankruptcy procedures are applied rigorously under a regime of hard budget constraints.

\section{LATVIA}

\section{Main Features of the Transition Reforms and their Outcomes}

By the end of 1992, only prices of energy and utilities for household use, approximately 8 percent in the consumer price index, remained under control.

Unlike Estonia, which introduced a currency right away, Latvia adopted a two-stage currency reform. It introduced a parallel (with the ruble) legal tender rublis in May 1992. The lats, which replaced the temporary rublis, was introduced from March to October 1993. The exchange rate of the (fully convertible) lats, which is currently pegged to the SDR, is supported by central bank intervention.

The trade regime evolved from quantitative restrictions and licensing to moderately high and widely dispersed export taxes and import duties beginning 1992.

Real output decline of 35 percent in 1992, one of the steepest in transition economies, had recoverd to a growth of 2 percent in 1994 and a lower 1 percent in 1995 . The inflation rate which was 124.4 percent in 1991 zoomed to 951.2 percent in 1992 (fuelled by higher prices of energy imports and currency creation in the ruble zone) but was down to 
35.7 percent in 1994 and a still lower 25 percent in 1995 as a result of effective fiscal and monetary control. The budget was in surplus at 1 percent of GDP in 1993 and unemployment was high at 4.9 percent of the laborforce. The situation had worsened in 1994: The budget deficit was 1.7 percent and unemployment was 6.4 percent.

Latvia's trade orientation to Western markets has been less effective than that of Estonia.

\section{The Trade Regime}

The trade regime is free from import licensing requirements (except for a few agricultural commodities) and export quotas.

However, export quotas and licenses which were abolished in mid-1992 were replaced by export taxes which varied from 2 to 300 percent and were higher on exports to CIS states and on barter trade. These discriminatory export taxes were calculated to prevent outflow of products to Russia and the CIS states, and redirect trade to the West. (Some rates were reduced by 1994.)

At the same time, import duties were introduced in September 1992 to counter the appreciating real exchange rate. The number of dutiable items and the average (unweighted) rate at 10 percent remained high in 1994.

The tariff law of December 1, 1994 specified basic rates of 1 percent for raw materials and spare parts, 20 percent for final, nonagricultural items, and 53 percent for agricultural products (all weighted by production). The corresponding MFN rates, which apply to "special" trading partners, are 0.5 percent, 15 percent, and 46 percent. The production-weighted agricultural tariffs on European Union imports are expected to decline to 38 percent by the year 2000 as a result of the June 1994 European Free Trade Agreement.

3. The Exchange Rate Regime

The Latvian lats, which became the sole legal tender on October 18, 1993, was pegged to the SDR in February 1994 at the rate of 1 SDR exchanging for 0.7997 lats. The exchange rates between the lats and convertible currencies (except the dollar) are based on the rates at which these currencies are traded against the dollar in international markets. (The official rate of the lats against the dollar was 0.512 lats in early 1994.) Banks and authorized exchange dealers are free to trade in these currencies.

The exchange rates between the lats and the currencies of Estonia, Lithuania, Russia and other post-Soviet states (which are also quoted weekly by the Bank of Latvia) are determined on the basis of their rates against the dollar or the deutschemark.

\section{Currency Convertibility}

The lats is fully convertible for current and capital account transactions. Foreign exchange earnings from exports and service transactions are free from surrender requirements. Residents, individuals as well as enterprises, can hold foreign currencies at home or abroad, in cash or in commercial banks. Similarly, nonresidents can hold bank accounts in Latvia in local or foreign currency.

\section{Direct Foreign Investment}

The Law on Direct Foreign Investments of November 1991 which was amended finally in March 1995 governs DFI in Latvia. There are no restrictions on repatriating capital or profits from investments by foreigners. There are no impediments to the entry of foreign banks but only one foreign bank operates in Latvia.

\section{The Institutional Infrastructure}

Laws relating to investment activity are as well drafted and implemented as in Estonia.

The Bank of Latvia and a number of commercial banks were established in the first phase of financial reform in 1992. The commercial banks numbering 63 at the end of 1993 lacked adequate capital, sound portfolios, the necessary banking skills, proper accounting procedures and an effective regulatory framework. The banking crisis of 1994, which led to the closure of one of the largest banks (Banka Baltija), was followed by a series of measures by the Bank of Latvia, among them increased supervision (by outside auditors) of the "core" banks which were licensed to accept household deposits. Toward the end of 1995, the Bank of Latvia had established its autonomy by implementing a strict monetary policy and by carrying out the supervisory and regulatory functions of a central bank.

A securities market started operating in July 1995 with the creation of the Riga Stock Exchange, the adoption of the necessary legal framework, and the setting up of a securities depository.

In August, Latvia launched a 4 billion yen two-year, international bond issue through Nomura, the Japanese 
investment bank.

On the whole, banks dominate the financial sector of Latvia. However, they provide meagre medium and long-term credit: Safe investment opportunities are limited; assets which can serve as collateral are hard to come by because factory privatization is slow; banks also lack the expertise to assess risks. As a result, their financing in the form of unsecured, short-term credits accounted for 70 percent of total bank credits in the economy at the end of June 1995.

\section{Industrial Restructuring}

Restructuring has emphasized strategic investment from outsiders including foreigners rather than factory insiders. However, the enforcement of bankruptcy procedures and of hard budget constraints is weak.

\section{LITHUANIA}

\section{Main Features of Transition Reforms and their Outcomes}

As a result of the price decontrol (which began in February 1991), prices were freed for 85 percent of the value of items in the consumer goods basket.

As in Latvia, a national currency was introduced in two stages. The temporary legal tender talona circulated with the ruble for almost a year beginning May 1992. The litas replaced the talona over a period from June to August 1993. It was pegged against the dollar in April 1994 under a currency board arrangement and is fully convertible.

Lithuania's trade regime too was liberalized in stages: 1991 witnessed the replacement of state trading by export licenses, quotas (with some items totally banned from export trade) and export taxes. Quantitative restrictions and licenses for export activity were reduced in 1992 and 1993; import duties were moderated from mid-1993 to mid-1994 and changed several times.

Until the introduction of the fixed exchange rate regime in April 1994 under a currency board arrangement, monetary policy was influenced by political pressures to prevent a sharp real appreciation of the flexible litas via increased supplies of the currency which fuelled inflation (Sorsa, 1995).

As a result, inflation (measured in consumer prices) was higher than in Estonia and Lithuania--1,020.5 percent in 1992, 410.4 percent in 1993, 72.1 percent in 1994 and 35 percent in 1995. Real GDP which had declined by 37.7 percent in 1992 and 24.2 percent in 1993 was up by 1.7 percent in 1994 and 3 percent in 1995 . But the unemployment rate had also increased from 1 percent at the end of 1992 to 4.2 percent by the end of 1994 and (was projected to rise) to 6.6 percent in 1995 .

\section{The Trade Regime}

There are no quantitative restrictions on imports. Export restrictions have been largely eliminated. However, the trade regime with respect to import tariffs has continued to be unstable. Frequent changes in these rates--13 times from February 1993 to February 1995--have resulted in higher rates on agricultural imports and wide dispersion in the tariff structure. A three-tier tariff schedule (which was announced on December 30, 1994) granted (i) MFN status to imports from countries with a "foreign policy priority," (2) preferential treatment to Foreign Trade Agreement partners, and (3) and an "autonomous" rate (which is 5 to 10 percentage points higher than the MFN rate) to the remaining countries. The average, consumption-weighted tariff rate on 8 groups of agricultural products was raised from 24 percent in April 1994 to 44 percent in July 1994 and reduced to 35 percent in October 1994.

As a result of the Free Trade Agreement with the European Union (which became effective on January 1, 1995), the trading partners abolished quantitative restrictions and tariffs on trade in industrial products except textiles. The average, weighted tariff on agricultural imports into Lithuania will remain at 35 percent till the year 2000 .

\section{The Foreign Exchange Regime}

Under the currency board arrangement adopted on April 1, 1994, the litas has been pegged to the dollar at the rate of 4 litas per dollar.

\section{Currency Convertibility}

Foreign exchange earnings from exports of goods and services need not be surrendered and may be retained abroad. Foreign exchange for imports of goods and services is available freely. Foreign currency transactions are carried out by commercial banks which are licensed for the purpose by the Bank of Lithuania. Citizens and enterprises can 
operate their foreign exchange accounts with domestic authorized banks freely. These banks can freely borrow abroad or loan funds in foreign currencies to residents and nonresidents alike.

\section{Direct Foreign Investment}

The Law on Foreign Investments of December 1990 (which was later amended) allows unlimited repatriation of after-tax profits and invested capital. In 1995 the Lithuanian parliament removed the tax incentives to foreign investors which were granted earlier. The current law requires that 25 percent of the committed funding must be brought in by the foreign investor when the enterprise is established.

\section{The Institutional Infrastructure}

Laws relating to investment activity, often drafted by unqualified personnel, tend to be unclear. Nor are they administered effectively.

The commercial banking sector in Lithuania is being consolidated with the number of banks having declined from 28 in 1994 to 20 in 1995 . These banks generally loan short-term funds for trading activity. Banks have been reluctant to undertake medium and long-term lending because of their inability to assess investment risks and because of the inability of borrowers to provide tangible assets as collateral. Since the passing of the Commercial Banking Law in December 1994, the Bank of Lithuania has intensified its supervision of commercial banks.

Lithuania has a stock exchange and brokerage firms which deal in stocks, treasury bills and privatization vouchers.

\section{Industrial Restructuring}

Worker collectives and old managers, who favor job security over restructuring, have substantial stock ownership in corporatized factories. Few firms have been subjected to bankruptcy procedures.

\section{RUSSIA}

\section{Main Features of the Transition Reforms and their Outcomes}

Prices of food items and most consumer goods were released in early 1992. Prices of monopoly products and raw materials (among them oil and gas) were decontrolled gradually. A presidential decree of March 1995 stipulated that all price controls be removed except for items produced by natural and state monopolies. Domestic price of oil, which was about 70 percent of foreign price by mid-1995, had moved down to 40 percent in early 1996 . Gas price differential was bigger. Prices of energy and transport for household use, and of housing (which was being handed over to local administrations) were raised in stages. Some localities continue to subsidize consumer purchases of essential food items.

A tax on average wage of enterprises in excess of the official minimum wage (by a multiple of six times in 1995) was set to be removed in 1996. Pensions and wages of state employees have been raised periodically.

By mid-1993, the central bank refinance rate followed the interbank interest rate. Beginning 1994, real interest rates on credits have been positive with the exception of the November 1994 to January 1995 period.

The budget deficit was sought to be reduced from its estimated 17 to 21 percent of GDP in 1991 to zero in the first quarter of 1992. The removal of consumer subsidies and cutback in industry support, defense expenditures and state-financed investments were Soviet-style fiats and did not involve negotiations with the public or the Supreme Soviet (the parliament).

In 1993 and 1994, the fiscal deficit management repeated the pattern of 1992: Deficit control of the early months was reversed in late summer via increased budgetary allocations (to support agricultural activity and prepare the Northern Territories for the winter months). Budgetary management in 1995 broke this pattern with steady control of the deficit through the year. However, the lagging revenues, running at 60 percent of projections in late 1995, forced authorities to enforce arbitrary cutbacks and postponement of discretionary spending, among them wage payments to state employees. Inflation control in 1995 was also helped by a stricter and more effective monetary policy.

The steady control of inflation in 1995 prompted the government to modify the exchange rate policy in mid-1995: The exchange rate was to be maintained till end of the year via central bank intervention within a band of 4,500-4,800 rubles to a dollar (in contrast to the earlier managed float which shied away from such an explicit corridor). The band was widened to 4,800-5,150 rubles to a dollar for implementation till mid-1996. 
The stabilization policies resulted in inflation control (measured in consumer price index) from 1,353 percent in 1992 to 896 percent in 1993, 302 percent in 1994 and 190 percent in 1995 . The real GDP decline of 19 and 12 percent in 1992 and 1993 (which reflected, in part, the breakdown of traditional economic and trade ties with the FSU states), and of 15 percent in 1994 (which was largely in response to the stabilization measures and relative price changes) had bottomed out with a 4 percent decline in 1995. Open unemployment as a percent of the labor force was 7.4 percent in January 1995.

The trade balance with non-FSU partners was positive in 1994 and 1995 reflecting improved export performance which kept ahead of resurgent import demand. Dollar exports of energy products, timber and metals, 70 percent of the total in 1995, grew by 18 percent reflecting sluggish domestic demand. Toward the end of 1995, official foreign exchange reserves were estimated at 12.5 billion dollars, worth approximately 3 months of imports.

The continuing output decline in the first quarter of 1996 and lagging tax collection coupled with the spending surge on the eve of the June presidential elections raised serious doubts about the fulfillment of the 1996 budget deficit target (at 3.9 percent of GDP) and inflation control (at monthly 1.9 percent by December 1996).

\section{The Foreign Trade Regime}

The state monopoly of foreign trade was dismantled in 1992.

Major exports were subject to quotas and taxes till the end of 1994. Authorities also controlled export activity for these commodities which were classified as "strategically important." (Only special exporters were authorized to export these items.) The phasing of quotas and export taxes (the latter to be replaced by excise duties) began under IMF pressure in early 1996. However, export quotas on oil trade were maintained indirectly by an interagency committee which regulated pipeline access.

Import trade was freed from licensing requirements and quotas in January 1992 but some imports were subsidized till January 1, 1994. Basic rates of 5 to 15 percent import tariffs were introduced on July 1, 1993. A new import tariff schedule with a higher average rate of 12.5 percent and a wider range was introduced beginning July 1994 . The average tariff on a number of commodities was 15 percent in 1995. "Temporary" tariff hikes and export quotas, for example, on fertilizers (the latter to keep domestic prices artificially low) were announced on the eve of the June 1996 presidential elections.

Trade with the FSU states is marked by administrative controls and barter agreements.

Russia has applied for membership to the WTO. In early 1996, it sought entry into the OECD by arguing that it was a democracy, had completed market reforms, and had further reforms on the agenda.

\section{The Foreign Exchange Regime}

The exchange rate for current account transactions was unified on July 1, 1992 and was allowed to float (in terms of the dollar). It followed the quotations, twice a week, of the Moscow Interbank Currency Exchange (MICEX). The Central Bank of Russia (CBR) intervened in the market to prevent wild fluctuations in the exchange rate which has appreciated in real terms since January 1, 1993.

The policy of managed float was altered in mid-1995 and the nominal exchange rate was allowed to vary within a fixed band of 4,300-4,800 rubles to a dollar. The band was moved up to 4,800-5,150 rubles to a dollar on the eve of the December 15 elections to the Russian Duma (lower house of the parliament) with a view to making exports and import substitutes more competitive.

The CBR announced a further upward shift of the crawling corridor, to begin on July 1, 1996 at 5,000-5,600 rubles to a dollar and end at 5,500-6,100 rubles to a dollar on December 31. It also committed itself to prevent the ruble from falling more than 1.5 percent a month, slightly lower than the monthly inflation pledge of 1.9 percent in the second half of 1996. The CBR would eventually like to land on a stable and realistic nominal exchange rate. Its success en route in switching from a crawling band to a crawling peg (as in Hungary and Poland) and moderating the real appreciation of the ruble (contrary to the earlier pattern) with a view to keeping exports and import-substitutes reasonably competitive will depend on whether the steady decline of the inflation rate from 3.2 percent in December 1995 to 2.2 percent in April 1996 can be maintained.

\section{Currency Convertibility}

A flexible, current account convertible and unified exchange rate was in place in Russia at the start of 1994. However, capital account transactions for residents and nonresidents, individuals and corporate entities continued to 
be restricted.

On June 1, 1996, the CBR abolished the surrender requirement of foreign exchange earnings from exporters by signing IMF Article VIII on full current account convertibility.

\section{Direct Foreign Investment}

Foreign investors can repatriate their profits. They however face unclear property rights and contract law, inadequate law enforcement against criminal elements, unpredictable taxes, and excessive regulations which continue changing. DFI in the energy sector is hampered by jurisdictional disputes over the control of natural resources by local, regional and federal authorities, and lack of a transparent legal framework. The government's announcement of preferential treatment of foreign investors in the oil industry has not been followed by the necessary legislation. As a result, prospective investors have shied away from investing in the Russian oil sector.

From January 1991 to October 1995, DFI had cumulated to $\$ 4.9$ billion, far below the economy's potential. Some regions such as oil-rich Tyumen in Western Siberia and the Far Eastern port of Vladivostok has attracted foreign investors because of natural resources and good location. Others such as Tatarstan, Nizhny Novgorod, and Samara south-east of Moscow have succeeded with aggressive marketing ranging from tax breaks to water subsidies. The prospects of DFI have improved as result of Yeltsin's re-election as president following upon the 10.2 billion three-year credit agreement with the IMF in March 1996, steady inflation decline, and a bulging trade surplus (estimated at $\$ 16$ billion in mid-1996).

\section{Institutional Infrastructure}

Investment activity, domestic and foreign, is not only hampered by too many conflicting and changing laws but also by a chaotic financial sector and outdated physical infrastructure.

The Russian economy witnessed an unprecedented and unregulated growth of commercial banks, most of them "pocket-sized parasites," (2,561 on June 1, 1995), investment funds (650 in 1995), insurance companies (2,700 in 1995) and private pension funds (600 in 1995). Several undercapitalized banks were closed in 1995. Investment and pension funds have been subjected to tighter supervision.

Foreign banks are subject to limits on authorized capital; foreigners are not allowed majority ownership in the insurance business.

70 authorized stock exchanges and 100 commodity exchanges (with stock exchange departments) operated in 1995. Credit instruments of a modern market economy, among them government bonds and treasury bills, municipal bonds, corporate and bank shares, and hard currency certificates currently trade in these outlets. The volumes have been increasing although their prices are volatile and the risks are enormous. Legislation on a full-fledged securities market and joint-stock companies is expected to be adopted in 1996.

7. Industrial Restructuring

There have been few actual bankruptcies. Insider ownership of large factories has prevented rapid inflow of outside funding and managerial expertise. Selective budgetary support of the defense sector and the coal industry has continued. But budget constraints have increasingly become hard.

The continuing opposition of the Communist and Agrarian parties to the sale of government stock to outside investors including foreigners is likely to slow restructuring in the coming months because of their increased representation in the Duma elected in the December 1995 elections.

\section{KAZAKHSTAN}

1. Main Features of the Transition Reforms and their Outcomes

Transition reforms picked up speed in Kazakhstan toward the end of 1993 when an independent currency, the tenge, was introduced on November 15, 1993.

Administered prices of bread, grain products and fodder were completely freed in October 1994; oil and coal prices were decontrolled in April and May 1995.

The lax financial policies of the first half of 1994 were reversed in the latter half: The budget deficit of 16 percent of GDP was turned into a surplus of about 4 percent in the third quarter.

The severe fiscal adjustment which was supported by tight credit policies resulted in a sharp decline in inflation from 46 percent in June 1994 to a core monthly rate of 10 to 12 percent toward year end, positive real interest rates and 
a virtually stable real exchange rate.

Real GDP declined by 25 percent and unemployment was 11 percent of the workforce in 1994. Average real wages by September-end 1994 were half their level at the end of 1991. The inflation-output performance was projected to improve but remain critical in 1995: The rate of inflation was forecast at 180 percent and output decline at 12 percent.

There was a sharp decline in 1994 trade volume: Exports of oil fell because of major interruptions through the year in the use of Russian pipelines and imports fell because of tight credit policies and lower export earnings. Non-FSU trade (exports plus imports) was approximately 40 percent of the total.

\section{The Trade Regime}

The trade regime till the end of 1994 was marked by export quotas (which were brought down to include 7 items), export licensing, and monopoly of state-owned companies in trading "strategic commodities." Only 20 percent of export quotas were distributed via auctions. The government abolished all export quotas except those on oil and oil products and distributed more export quotas via auctions in 1995.

Oil exports to non-FSU states however are constrained by access to Russian oil pipelines and the formidable problems of creating alternative routes of deliveries to the outside world. This issue remained unresolved in 1995.

There are no quantitative restrictions on imports. In April 1994, the authorities removed customs duties on most imports except on alcohol, cars, furniture, carpets, and leather goods. The rates are 5 percent or less except on cars and alcohol.

A Partnership, Cooperation and MFN Agreement with the EU signed in January 1995 is aimed at establishing closer economic and political ties with the EU and liberalizing mutual trade. Tariffs on imports were abolished by Kazakhstan and Russia as a result of an agreement in early 1995. However, Kazakh authorities unilaterally slashed tariffs on a number of manufactured goods imports from third countries in April 1996 threatening Russian exports.

\section{The Exchange Rate Regime}

The exchange rate of the tenge (the Kazakh currency which was introduced on November 15,1993 ) is determined in weekly interbank auctions. The nominal value of the tenge moved up from 4.68 tenges for a dollar in November 1993 to 50.5 tenges by May 1994. (It remained there till September 1994.) However, the tenge appreciated in real terms because the inflation differential was higher than the rate of decline in the nominal value of the currency. The National Bank of Kazakhstan intervenes in the currency market in a limited fashion to prevent sharp fluctuations or a rapid appreciation in the real exchange rate.

\section{Currency Convertibility}

The exchange rate was unified when the tenge was introduced in November 1993. Centralized allocation of foreign exchange for imports was also removed. The surrender requirement for export earnings was abolished in August 1995. However, there are limitations on foreign exchange allowances to Kazakh citizens for travel abroad and to enterprises for current account transactions. Nonresidents cannot freely convert tenge accounts into foreign currency and transfer it abroad.

\section{Direct Foreign Investment}

Foreign companies, consulting and legal firms, and banks have opened offices in Alma Aty. The government has invited tenders for five year contracts from foreign companies to mangage 18 large enterprises. Projects for investing several billion dollars in the Tenghiz and Karachagank oil fields, for construction of an oil pipeline, and for energy exploration in the Caspian Sea have been drawn up by several foreign corporations. A serious obstacle is Kazakhstan's inability to export oil and other industrial raw materials without reaching an agreement with Russia on access to the outside world.

A protocol signed in April 1996 by Russia and Kazakhstan on the construction of a $\$ 2$ billion pipeline linking the Tengiz oil fields of Western Kazakhstan to the Russian port of Novorossisk promised to unblock numerous foreignfinanced oil and gas projects in Kazakhstan, Turkmenistan and Azerbaijan. As a result, Russian, Kazakh and Oman negotiators and Western oil companies have begun the process of resolving complex issues of tariffs, taxes and management control over the pipeline.

The authorities passed new laws in 1994 to make Kazakhstan more attractive to foreign investors by allowing them to repatriate profits and the original investment. In case of nationalization or expropriation, the foreign investors 
are to be granted prompt, adequate and effective compensation which will be paid in the currency in which the investment was made. In practice, the implementation of these generous provisions is hindered by foreign exchange shortages. The Tax Code of July 1, 1995--one of the best written and comprehensive among the CIS states--specifies a tax rate of 30 percent for Kazakh enterprises and permanent establishments of foreign companies.

There are no export performance or import content requirements or restrictions on hiring foreign personnel.

6. The Institutional Infrastructure

Laws governing investment activity exist but their implementation is not guaranteed.

Kazakhstan lacks the necessary financial institutions for stabilizing the economy and attracting foreign investment.

Specialized state banks, which hold 80 percent of the banking system assets, continue to channel credit in the economy. In 1994, the National Bank of Kazakhstan began supervising and regulating commercial bank activity by imposing reserve requirements on tenge deposits, introducing a reserve backing of 15 percent on foreign currency deposits, enforcing stricter capitalization requirements for commercial banks, and introducing proper accounting procedures.

The Central Asian Stock Exchange operates in Alma Aty.

\section{Industrial Restructuring}

The process has been stalled by delays in adopting legislation governing the restructuring of 400 large factories. Bankruptcy procedures and labor laws are biased against laying off workers.

\section{UZBEKISTAN}

1. Main Features of the Transition Reforms and their Outcomes

Prices were freed for all items in 1994 except those for flour, sugar and vegetable oil (which were also rationed) and for monopoly products. Rationing, and price ceilings (except for natural monopolies) were discontinued in 1995. Energy prices are based on costs of supply including changes in world prices and in the exchange rate of the sum, the Uzbek currency. Toward the end of 1995, domestic wholesale prices of oil and oil products were at or above world levels. The difference between industrial and household rates for electricity and gas was being reduced. Local governments however continued to subsidize utility prices including those for household energy, transport and housing. Wages and pensions are adjusted to keep pace with inflation. The central bank refinance rate has been based, since March 1995, on the interbank money market rates. The monthly refinance rate was 7 percent in December 1995, substantially above the consumer price inflation of 4 percent.

The Uzbek authorities introduced a national currency, the sum, in two stages. Following the breakdown of negotiations on the formation of a new ruble area in 1993, they issued the sum-coupon (at a par rate of exchange with the ruble) in November 1993. However, with a continuing depreciation of the sum, the link with the ruble was cut and the coupon was allowed to vary beginning April 1994 according to its value in foreign currency auctions. At the same time, financial policies were tightened so as to reduce inflation and stabilize the exchange rate in anticipation of the introduction of a national currency. The Central Bank of Uzbekistan (CBU) raised its rediscount rate several times and cut back credits to unviable enterprises.

The sum was then introduced at an initial exchange rate of sum 7 per dollar on July 1,1994. The official and market rates were unified in October and the sum was made the legal tender for all internal transactions.

Despite the stabilization measures, the inflation rate remained high and volatile in a three digit range finally declining to 325 percent in 1995 from a high of 785.1 percent in 1994. Real GDP growth rate decline of 11.1 percent in 1992 was slowed to 4 percent in 1995. Open unemployment was 4.5 percent of the workforce in 1994 . This estimate does not include the 1 million underemployed in the agricultural workforce of about 2.7 million. Finally, the budget deficit was estimated at 4.1 percent of GDP in 1994.

The old state order system, which contributes to production and consumption distortions, has continued into 1996. The below-world-price state procurement targets for cotton and grain of Janaury 1996 were as high as 50 percent of the 1996 crops. The procurement prices for the two crops were also fixed at 70 and 60 percent of the world prices.

Reflecting close production and trade ties with FSU states, Uzbekistan's FSU trade was 55 percent of the total in 1993. Exports were dominated by cotton and cotton fiber, textiles and textile machinery. 


\section{The Foreign Trade Regime}

Foreign trade remains tightly controlled. 60 to 65 percent of trade with FSU and non-FSU partners was carried out through state channels in 1994. The growing private sector was controlled via export licenses and quotas, and import licenses. The Ministry of Foreign Economic Relations continued to register and review contracts and agreements by private parties which required licenses and agreements involving intergovernmental negotiations and centralized deliveries. In 1994, Uzbekistan had bilateral agreements with 17 countries.

The number of commodities requiring export licenses has been reduced over time from 26 to 11 toward the end of 1994. A further reduction was planned by the end of 1995. All licensing of goods, except for cotton, and export bans were to be eliminated by January 1997. Import and export duty rates were to be simplified during 1996. Joint ventures and wholly-owned subsidiaries can export their products without a license.

Import duties have been adjusted or removed to increase supplies of essential items such as grain, sugar, machinery and parts, and oil. For example, the January 21, 1994 decree removed all import duties until July 1, 1995. Uzbekistan has an observer status with the WTO.

\section{The Foreign Exchange Regime}

The exchange rate arrangements were changed several times during 1994.

On July 1, 1994 a national currency, the sum, was introduced at an exchange rate of sum 7 per dollar. The gap between the official rate of the sum determined by the Republican Currency Exchange and the open market widened over the months. These exchange rates were unified on October 10,1994 at the rate of sum 22 for a dollar. The CBU intervenes in the exchange market to soften sharp flctuations in the rate but does not target it. In view of the uncertainty of the proper level of the real exchange rate and the possibility of unexpected foreign exchange inflows, pegging of the exchange rate is currently ruled. If the auctions continue to function smoothly, the authorities intend to reduce the surrender requirement of 30 percent of export earnings and eliminate it by the end of 1996. The auction-determined exchange rate between the sum and the dollar is used for all official exchange transactions. The spread between the (higher) cash exchange rate charged by the foreign exchange bureaus and the (lower) auction-determined rate, which was 40 percent in October/November 1995, had narrowed to 20 percent by mid-December and remained there in early 1996.

\section{Currency Convertibility}

30 percent of foreign exchange earnings must be surrendered at the market rate of exchange to the CBU by state as well as private exporters. The CBU passes on half the amount to the Ministry of Finance which transfers it to the Republican Foreign Exchange Fund which in turn finances the needs of the government and meets its obligations.

The Ministry of Foreign Economic Relations having approved the foreign exchange needs for merchandise trade by state agencies allows the remainder to be used for their current account transactions. (Private importers can acquire foreign exchange from the auctions.)

Residents can buy any amount of foreign exchange, and can take up to $\$ 500$ out of the country without documentation of how the currency was obtained. Nonresidents can carry foreign exchange brought by them according to customs declaration.

Residents and nonresidents, private indiviuals and companies, are allowed to open and operate convertible currency accounts with local banks and receive interest on them. These accounts can be used for transferring funds abroad subject to regulations.

\section{Direct Foreign Investment}

Joint ventures with foreign partners must register with the Ministry of Finance and must be licensed by the Cabinet of Ministers. The President must approve large investment projects. Joint ventures enjoy a two-year tax holiday except those in the priority sectors (such as agricultural and textile processing, mining, oil and gas industries and tourism) which can claim a five-year holiday. Joint ventures can export their products and import inputs without licenses and retain all foreign exchange earnings. 100 percent foreign equity participation is allowed. Foreign investors may purchase local products for exports in lieu of cash profits which can be repatriated by joint ventures (with a foreign share of at least 30 percent) after payment of a 10 percent tax. In practice, currency restrictions and bureaucratic hassles persist. Corruption is widespread. The laws also tend to change frequently.

Despite the substantial endowment of mineral resources, among them nonferrous metals, gold, and natural gas, 
foreign investment is constrained by the difficulties of exporting the materials through the trade routes which run through Russia.

\section{The Institutional Infrastructure}

Laws, often in the form of executive decrees, exist but they are badly drafted and difficult to enforce. The roads, railways and telephone systems are outdated creating massive hurdles for investors and traders. The underdeveloped banking, financial, accounting and data-collecting systems inhibit foreign investment and trade.

Two state banks, the Agroprombank and Promstroibank dominate banking activity in the industrial sector, and the National Bank for Foreign Economic Activity continues to channel the flow of foreign exchange.

A Republican Stock Exchange, a National Share Depository, and a National Investment Fund were set up in 1994.

\section{Industrial Restructuring}

Insider ownership of large factories and the political risks of large-scale labor layoffs have prevented the initiation of bankruptcy procedures. Budgetary support of factories has continued.

\section{VIETNAM}

1. Main Features of the Transition Reforms and their Outcomes

Under the doi moi (renovation) reforms which began in 1989, price controls were largely phased out and the distortionary dual price system was laid to rest.

The budget deficit was reduced via a cutback of government expenditure (with revenue remaining constant) of 6 percent between 1989 and 1991.

The authorities controlled inflation by dramatically raising the lending rate on bank loans above the level of inflation (to 9 percent per month in the spring of 1989 when inflation was about 7 percent), and deposit rates to an even higher level.

They also unified the various controlled exchange rates in 1989 and devalued the unified rate to the level prevailing in the parallel market. This implied a 73 percent real devaluation which, combined with the relaxed administrative procedures for imports and exports, increased the profitability of exporting.

Prior to 1989, external trade was monopolized by a small number of state trading companies. This system was liberalized first by allowing competition among state trading companies and later, by letting private firms engage in trade via quota allotments and import shipment licenses from the Ministry of Foreign Trade. As a result of the stabilizaton measures, inflation declined from 400 percent in 1989 to 72.5 percent in 1991 and 14.5 percent in 1994 rising to 19.8 percent in 1995 . GDP growth of 6.3 percent in 1991 had steadily gone up to 9.5 percent in 1996. The budget deficit which had ranged between 5 to 10 percent of GDP in 1985-1989 was down to 3.3 percent in 1994.

During most of 1989-1994, export growth averaged more than 25 percent per annum driven by rice and energy (oil and coal) exports.

Liberal DFI policies have promoted substantial foreign investment from ASEAN neighbors (from which Vietnam imports) into manufacturing (oil and tourism in the early years) which has been the leading source of exports in recent years.

\section{The Foreign Trade Regime}

Import restrictions, in order of decreasing transparency, include tariffs, reference prices, excise taxes, quotas and import licenses (Kokko and Zejan, 1996). The traiff structure currently includes 28 rates ranging from 0 to 100 percent. The average tariff rate is 15 to 20 percent. However, two-fifths of imports, according to the Ministry of Foreign Trade, are subject to rates of 40 percent or higher. Again, tariffs on several goods are levied on reference prices (which are set at higher levels than the c.i.f. prices declaed by importers) to counter under-invoicing of imports. Excise taxes, which are levied on imports (at times to counter reduction of import tariffs) also prevail (ibid).

The import legislation remains cumbersome: Occasionally, finished products are protected at higher rates than intermediate items, thereby resulting in large and inefficient effective protection. In other cases, the rates are higher on intermediate than on final products creating negative protection for assembly line operations. The tariff code needs to 
be simplified before vested interests develop a stake in retaining the current arrangements.

The Agreement with the European Union concluded in 1995 is expected to increase trade with the EU. The normalization of diplomatic relations with Washington also improved prospects for trade and investment flows from the U.S. Of greater significance in this regard is Vietnam's entry as a seventh member of the Association of South East Asian Nations (ASEAN) in July 1995. Vietnam has been given a ten-year grace period during which it must moderate tariffs and eliminate trade restrictions. A year later, Vietnam asked to join APEC, the Asia Pacific Economic Cooperation forum, the 18-member group formed in 1989 to promote regional trade.

\section{The Foreign Exchange Regime}

The foreign exchange arrangements had three phases.

The exchange rate was allowed to devalue during 1990 and 1991 in line with the moderate inflation.

In 1992, the authorities pegged the currency against the dollar in order to bring inflation from the 70 percent range to single digits. Thus, the real exchange rate appreciated as inflation was brought under control in 1992 .

By early 1993, the fixed exchange rate was abandoned in favor of a crawling peg policy (of allowing the exchange rate to devalue in line with domestic inflation) because inflation was brought under control. (The authorities did not have enough foreign exchange reserves to support the "anchor" for long.) The resulting real appreciation affected export competitiveness negatively.

\section{Currency Convertibility}

The dong is convertible for current account transactions. Exporters are however not allowed to keep foreign exchange abroad and must surrender it at the market rate of exchange by depositing it in local banks. Foreign investors can repatriate profits freely. Vietnamese citizens are not allowed to open foreign exchange accounts abroad.

\section{Direct Foreign Investment}

DFI has taken place in joint ventures with state-owned enterprises in protected sectors of the economy such as heavy industry, transport and communications, financial services, and distribution of agricultural inputs and products. Hong Kong and Taiwan have remained the top investors. owever, investment projects actually undertaken have remained far below committed amounts, at about 20 percent by 1995. In fact, about 12 percent of licensed DFI during 1988-1993 was subsequently withdrawn (ibid).

While foreign investors were initially attracted to Vietnam by low wages and investment incentives, they have subsequently faced high costs arising from delays, conflicting rules and bureaucratic snafus, and shortages of essential services such as water and power.

Irreconcilable differences with domestic partners have been pushing foreign investors to search for wholly-owned ventures. Indeed, some have pulled out of the country from high profile investments: A French company scuttled a $\$ 1.2$ billion oil refinery project on account of disagreement over where to locate it. An Australian group abandoned plans to develop port facilties in Ho Chi Minh city after protracted negotiations. Two Japanese companies pulled out of prospective funding of a supermarket and a steel plant because the Vietnamese side felt they offered too little investment.

In October 1995, the Vietnamese National Assembly approved the merger of the State Committee for Co-operation and Investment (SCCI) and the State Planning Committee (SPC) with the aim of improving the investment climate in the economy.

\section{The Institutional Infrastructure}

Much time and effort are needed to push a project for approval by a meddlesome bureaucracy through a maze of overlapping legislation.

The banking system consists of the State Bank of Vietnam, four state-owned commercial banks (which specialize in trade, development, industry and agriculture), about 50 private, joint- stock banks and 3 foreign, joint-venture banks. Branches or representative offices of 60 foreign financial institutions also operate in Vietnam. 200 credit co-operative banks and credit funds serve the financial needs of the rural areas.

However, the state banks lack strict auditing and most of the joint stock banks are undercapitalized or insolvent. There is a fledgling bond market but no stock exchange. A secondary market for government securities does not exist. The rural population prefers to keep its savings at home, in foreign currencies, or in precious metals. The 
underdeveloped financial system is not geared to cope with the demands of a growing economy.

\section{Industrial Restructuring}

A major disincentive for western, market-oriented investors arises from the fact that the bulk of the economy remains publicly-owned and government-controlled. Only 3 out of an estimated 6,000 state-owned enterprises have been privatized. Investors are also discouraged by a 1995 legislation which prevents private ownership of land. State ownership, however, has not daunted ASEAN entrepreneurs from investing in Vietnamese industry.

\section{CHINA}

\section{Main Features of the Transition Reforms and Their Outcomes}

When Deng Xiaoping launched reforms in China in 1978, the economy did not have a macroeconomic stabilization problem internally (marked by huge budget deficits) or externally (evidenced in balance of payments deficits). Rather, the problem was lack of microeconomic incentives to households, farms and factories under the Maoist planned system.

The Deng reforms provided these incentives to farm households during (1978-1984) by virtually dismantling the communes (1979-1981), allowing the households to lease their plots from the state, and sell part of their outputs at fixed prices to state procurement agencies and the remainder at market prices in nonstate outlets. Again, town and village administrations were allowed to set up township and village enterprises (TVEs) for the production and sale of manufactured items outside the state plan.

The planners also sought to promote industrial efficiency by giving greater autonomy to state factories to set contract prices, select their inputs and outputs, and pay a corporate tax to the state in place of the earlier automatic contribution of profits to the state budget. This measure, the counterpart of the family household responsibility system in the farms, has failed because these factories have continued receiving support from the budget which in turn has strained effective budgetary management.

The overall budget surplus of the pre- 1978 years was beginning to turn into deficit which exceeded 10 percent of GDP beginning 1990. Budgetary support, overt and covert, to unviable state enterprises amounted to 3.5 percent of GDP. (For most of 1978-1994, however, inflation remained below an annual 10 percent because the deficit was financed partly by an inflation tax on houeshold savings, in the form of bank deposits, which had evidently climbed from 30 percent of GDP in the 1980 s to 40 percent by 1994.)

The fiscal problem in turn was exacerbated over time by the inability of the People's Bank of China (PBC) to impose credit controls and reserve requirements on the banking system which has operated with susbtantial excess reserves and has generously responded to the demand for loans. The provincial banks, in fact, are linked to the provincial governments. Since the 1980's, reserve requirements and administered interest rates have become monetary tools though both have limited effectiveness.

Price decontrol, a necessary policy tool, which (combined with fiscal and monetary discipline), can promote microeconomic efficiency has proceeded haltingly in China. Farm product prices were freed in 1985 followed by decontrol of several manufactured consumer goods in 1988. At that time, however, a two-tier price system was introduced for critical inputs among them steel, crude oil, cement, coal and rail transport. Factories bought and sold at official prices for state quotas but transacted at market prices beyond these amounts. The system promoted distortions penalizing and rewarding factories at random, and led to corruption. Most prices were raised in January 1991, and the dual system was abolished for cement.

In the realm of foreign trade planning, the initial import-substitution policy was abandoned in 1978 in favor of an "open door" orientation marked by gradual relaxation of trade and exchange rate arrangements: Provincial and local administrations (as well as Foreign Trade Organizations, FTOs) were allowed more freedom to retain foreign exchange, set up special economic zones, and attract foreign investment especially from nearby Hongkong which, after an initial trickle, turned into large flows beginning 1991.

The outcome of the policies has been impressive GDP growth and export performance respectively of 9 percent and 14 percent annually from 1978 to 1994 . The remarkable growth of new industry in the coastal regions assisted by DFI flows has reduced the share of the moribund state sector. However, the real GDP growth rates have fluctuated in the 1990s (having declined from 11.9 percent in 1994 to 10.2 percent in 1995) and inflation control remains a major battle for the policymakers: The consumer price index had jumped by 21 percent in 1994 and by a lower but still large 
14.8 percent in 1995.1996 growth rate is forecast at a "low" 8.9 percent, the result of strict curbs on fixed asset investment which began in 1993.

\section{The Foreign Trade Regime}

Chinese trade liberalization has implied gradual freeing of commodity groups from trade restrictions and enhanced role for provincial and local authorities in foreign trade planning. For at least thirty years (1948-1978), trade policy was shaped by the goal of import substitution.

Foreign trade management during this phase was "import-driven": export levels were determined by import targets. The State Planning Commission and the Ministry of Foreign Trade set specific import and export targets. The FTOs sold the exports and bought the imports at domestic prices in types and quantities specified by the plan. Since the yuan was overvalued, the domestic-price revenues of the FTOs from exports did not offset the costs of imports in yuan. The difference was covered by government subsidies to the FTOs at the levels that implemented the import targets. Thus, the foreign exchange rate played no role in equalizing demands and supplies of foreign exchange.

With the announcement of the "open door" policy in 1979, trade policies and practices began to be relaxed. Branch offices of the old FTOs operated independently, provincial and ministerial FTOs proliferated, and provinces and enterprises were allowed to retain part of their foreign exchange earnings. "Restricted" imports were under the control of the Ministry of Foreign Economic Relations and Trade (MOFERT) but "unrestricted" imports could be imported by ministerial and provincial as well as MOFERT FTOs. Quantitative controls were eliminated for about 35 percent of imports in 1984. A system of duties and licenses for both exports and imports was introduced beginning 1980.

The 1988 reform reduced the coverage of the mandatory plan, and priority plan exports. The national FTOs and provincial administrations also entered into three year contracts with MOFERT in regard to their export targets, the share of foreign exchange to be handed to the central government, and the center's commitment to cover their export losses with subsidies. In 1991, the contracts were converted into annual agreements which were to be developed in negotiations with enterprises and provincial authorities.

Some imports continued to be canalized through specific FTOs and licenses in 1995. (Licensing applied to a quarter of imports in 1992.) Specific import controls were also used for protecting domestic industry. Finally, import tariff rates in early 1996 were among the highest in the world and were distinguished by their high variance.

On April 1 1996, the average (unweighted) tariff rate was reduced from 35.9 percent to 23 percent on about 5,000 items including 380 agricultural products. One-third of import quotas were scrapped. (Quotas were, however, retained on 34 agricultural items.) The new tariff rates varied from 3 percent on aircraft engines to 50 percent on bicycles, hi-fi systems and radios and 100 percent on autos, cigarettes and alcohol. The tariff cuts, which were higher on raw materials in short supply and on high-tech items than on manufactured goods, were designed to benefit domestic producers of the latter. At the same time, the cuts were not large enough to compensate Foreign Funded Enterprises (FFEs) for the removal of the tax exemption on their capital-equipment imports thereby pushing up startup costs of new projects. Despite the cuts, China's tariffs have remained higher, more numerous, and more dispersed than those of other large developing countries.

China's entry into the WTO has been in limbo and has awaited resolution of a number of issues relating to its slow pace of trade liberalization, less than satisfactory market access to partner countries, weak enforcement of market access agreements, and copyright abuses.

\section{The Foreign Exchange Regime}

China had a dual exchange rate regime during 1986-93. The official rate was adjusted periodically. A market-determined rate was set in the swap centers. Domestic enterprises and FTOs were required to surrender their export earnings at the official exchange rate. They however received a fraction of their export earnings as retention quotas which entitled the owner to repurchase foreign exchange at the official exchange rate. They could also trade the quotas in the swap market where the exchange rate was depreciated.

This scheme was liberalized in February 1991: Domestic exporters were reimbursed for most exports at the swap market rate for 70 to 80 percent of their export earnings. About 80 percent of trade transactions took place at swap market rates in 1993.

The retention quotas, which involved the official exchange rate, were abolished in April 1994 except for FFEs. Thus, Chinese firms were allowed to buy and sell foreign exchange freely. The retention quotas for FFEs were removed in July 1996 enabling them to deal in foreign exchange with commercial banks at the market rate of exchange. In sum, 
by mid-1996, Chinese and foreign banks could undertake current account transactions (including profit and capital repatriation by foreign firms) at a single, market-determined rate.

A unified exchange rate to be determined in an interbank market was introduced on January 1, 1994. The People's Bank of China announces a reference rate at the start of each trading day (based on the weighted average of the buying and selling rates of the yuan against the dollar at the close of the previous day), and buys and sells foreign exchange in order to maintain the reference rate within 0.3 percent on either side of the reference rate. 12 major cities were linked with the China Foreign Exchange Trading System (CFETS) in Shanghai on April 1, 1994. Domestic financial institutions can buy and sell foreign currency in CFETS on their own account, and foreign banks can use brokers for the purpose.

China's foreign exchange reserves were estimated at $\$ 81$ billion in March 1996.

\section{Currency Convertibility}

Domestic enterprises must sell foreign exchange earnings from sales abroad to designated financial institutions. By contrast, FFEs can retain all their foreign exchange earnings and deposit them in banks but must obtain approval from the State Administration for Exchange Control (SAEC) for purchases and sales of foreign exchange. Importers can purchase foreign exchange for trade not subject to quotas, licensing, or automatic registration by presenting commercial invoices or bills. It can be purchased for controlled imports only with appropriate approvals.

Foreign investors can repatriate profits abroad.

Chinese citizens can buy (and sell) foreign exchange and deposit it in local banks.

\section{Direct Foreign Investment}

China's policymakers discarded the strict limits against DFI in 1978.

They opened up the economy to foreign investors in 1979 (by enacting the Foreign Investment Law) in four Special Economic Zones (SEZs) in Guangdong and Fujian provinces which had transportation links to the outside world and connections with overseas Chinese. Decisions in regard to investment, land use, labor policies, finance, taxation and foreign trade were left to the jurisdiction of local administrations. Foreign investors also enjoyed lower income taxes and tax holidays.

DFI response till 1985, however, was low ( $\$ 0.5$ billion a year rising to $\$ 1.5$ billion annually in 1984-1985) because of bureaucratic red tape, poor infrastructure and shortage of skilled labor. The overheated economy in the final years also discouraged outside investors.

New measures were introduced and old arrangements were liberalized in the late 1980s. FFEs could deal in foreign exchange in the newly-opened foreign exchange swap markets; fully-owned foreign enterprises could be set up outside SEZs; indiscriminate levies on foreign enterprises were reduced; foreign investors who stepped into high-tech, exportable industries received higher tax incentives.

Deng Xiaoping's tour of the southern coastal areas in January 1992 gave a further boost to the process. Almost all major cities and provincial capitals set up their open development zones with a variety of tax incentives and local concessions. Consequently, DFI during 1992-1994 amounted to $\$ 72$ billion exceeding more than three times the cumulative amount of 1979-1991. The special zones accounted for 20 percent of China's exports in 1995.

In 1995, FFEs continued to be approved and monitored by the Ministry of Foreign Trade and Economic Cooperation or the SAEC. FFEs which created exports or foreign exchange, brought in new technologies, and developed infrastructure were readily approved and received incentives if they were located in the open economic zones. These incentives consisted of lower income and trade taxes, and input costs. Toward the end of 1995, foreign-funded joint ventures paid 15 percent corporate tax in China's special economic zones, 24 percent in some areas "open" for investment, and 30 percent elsewhere. (Chinese state enterprises paid tax at 55 percent.

By early 1996, the DFI guidelines had begun emphasizing participation in infrastructure development and in China's hinterland. The tax benefits were being phased out. The authorities were becoming choosier.

A special feature of DFI flows in China is the dominance of Hong Kong and Macau which provided 54 percent in 1995 in contrast to 8 percent each by Japan, Taiwan and the U.S.

\section{The Institutional Infrastructure}

The arrangements to attract DFI which apply to numerous zones and include various concessions are codified in 500 pieces of legislations which however do not specify the exact rules to be implemented by different authorities. 
They are therefore carried out differently from one region to another contributing to delays and arbitrariness.

The financial and physical infrastructure are inadequate for the requirements of a rapidly growing economy.

\section{Industrial Restructuring}

There is no progress on privatizing and restructuring the state sector in industry which is heavily overmanned, and subsidized via budgetary outlays.

\section{INDIA}

\section{Main Features of the Transition Reforms and their Outcomes}

For over three and half decades, India's import substitution industrialization development strategy was marked by investment in capital and intermediate goods (rather than consumer goods), a dominating investment and production role for the government rather than private industry in these sectors, and regulation of private sector decisions on capital formation and foreign trade through quantity controls rather than market instruments.

The government responded to the frequent balance of payments crises by adjusting the policy mix to deal with the immediate problem: Thus, it sought to overcome the lack of foreign exchange (for financing machinery imports for investment) during the second and third plans (1956-1965) by licensing the use of foreign exchange, relying on foreign aid, and introducing export incentives. It tried overcoming stagnant agricultural production during 1966-1968 by introducing the green revolution technology. When higher oil prices created an acute balance of payments crisis in 1974, it increased investment in the oil sector. It liberalized imports of raw materials, then of capital goods and high-tech items to boost capacity utilization and growth of output in industry during 1974-1984. But throughout the ups and downs, it continued the policies of regulating domestic investment and imports through direct controls till the 1990/91 (fiscal year April 1 to March 31) balance of payments crisis.

The economy's performance for over three decades was marked by low but accelerating real growth rate of GNP from annual 3.4 percent during 1969-1973 to 5.6 percent during 1985-1989; low inflation rates between 6 and 8 percent (except during the oil ciris of 1980-1984); accelerating budget deficit of the governemnt which climbed from 5.6 percent of GNP in 1969-1973 to 11.7 percent in 1985-1989. Fixed investment had gone up from 15.1 percent of GNP in 1969-1973 to 21.9 percent during 1985-1989.

The foreign exchange crisis of 1990/91 was caused by a steep rise in the price of oil and the susbsequent withdrawal from Indian banks of foreign exchange deposits by non-resident Indians. By March 1991, India's foreign exchange reserves could finance an import bill of only three weeks.

The new government which was elected in July 1991 agreed with the IMF to reduce the budget deficit from 8.4 percent of GDP in 1990/91 to 5.7 percent in 1992/93; to eliminate government control of foreign trade and foreign exchange management and in fact, reduce its direct role in investment activity by allowing private industry to step into sectors which had earlier been reserved for the public sector.

It abolished government licensing requirements for setting up factories and expanding them, for locating industry and for selecting material use. It raised foreign equity participation, earlier restricted to 40 percent, to 51 percent. It opened up the infrastructure sector for investment by private including foreign investors.

The exchange rate was unified and devalued by 50 percent in June 1991. Controls on imports of intermediate and capital goods were eliminated. They remain on some consumer goods imports. Import tariffs were gradually reduced from a maximum of 400 percent to 55 percent.

As a result, real GDP growth averaged 4.3 percent each in 1992/93 and 1993/94 and 5.3 percent in 1994/95. Export growth was up 22.2 percent in 1993/94 and 17 percent in 1994/95. Foreign exchange reserves of $\$ 21.5$ billion by the end of 1995 were worth 8 months of imports. However, the budget deficit of the entire government was large, 11.9 percent in 1993/94. The post-1996-election government has announced plans to trim the fiscal deficit within five years from 5.9 percent of of GDP in 1995/96 to 4 percent within five years.

\section{The Trade Regime}

Indian trade liberalization has proceeded on three fronts.

First, intermediate and capital goods can be imported without a license. However, licenses are required for imports of consumer goods and agricultural commodities. In 1995, the government allowed free imports of more commodities, among them pulses, sugar, edible oil, butter oil and skimmed milk powder. Again, the Special Import 
License (SIL) scheme which allows importers to buy an import license from exporters (to whom it is given as a proportion of their exports) was liberalized to include more manufactured consumer goods from 42 to 75 . The import duty on the liberalized consumer goods is 50 percent.

Second, 1995 also witnessed enhanced export incentives. The Export Promotion Capital Goods (EPCG) arrangements are extended to the service sector. (Exporters who promise to export four times the c.i.f. value of capital goods imports from the date of issue of the import license can import capital goods at a concessional tariff of 15 percent.)

Finally, import tariffs have been slashed and the tariff structure rationalized. The maximum tariff rate was lowered from 300 percent in 1990-91 to 65 percent at the start of 1994-95. Successive tariff reductions brought down the average, import-weighted tariff from 87 percent in 1990/91 to 27 percent in 1994/95. The 1995 tariff structure is less dispersed because peak rates have been lowered to 50 percent and duties on a variety of industrial inputs and raw materials have been reduced. Specific duties have been abolished.

In December 1994, the government signed Market Access in Textiles agreements with the European Union and the United States allowing a phased access of the Indian market for textile imports.

In March 1996, the government lifted more import licenses, from a total of 190 items.

\section{The Foreign Exchange Regime}

The Reserve Bank of India (RBI) intervenes in the foreign exchange market to maintain a stable, nominal exchange rate of the rupee against the dollar.

In 1994 and 1995, the RBI bought excess foreign exchange in order to prevent the surpluses in the capital account from causing the nominal and real exchange rates to appreciate thereby reducing the export growth. At the same time, the RBI also announced new measures to reduce the inflow of foreign exchange with a view to reining in its impact on money supply and the inflation rate. Thus, Indian firms could raise money abroad only for physical investment projects and could bring it in for a definite use. It made the foreign exchange deposits by nonresident Indians less attractive by raising the deposit time limit.

In early 1996, the RBI sold foreign exchange to prevent the rupee from depreciating and the momentum of the reform process from deteriorating as a result of a weakening currency. As a result, however, massive amounts of rupees were sucked out of the banking system forcing the RBI to undertake counter measures such as lowering the cash reserve ratio of commercial banks to ease the liquidity crisis.

\section{Currency Convertibility}

The Indian rupee is fully convertible for all current account transactions. Foreign investors can readily repatriate their profits.

In view of the substantial foreign exchange reserves, the rules governing the repatriation of foreign exchange earnings from exports have been gradually relaxed. So are the rules governing investment by Indian companies abroad.

Capital account controls continue for Indian citizens. They cannot convert rupees into foreign exchange for deposit or investment abroad. The foreign exchange allowances for travel abroad have been liberalized.

\section{Direct Foreign Investment}

The Indian DFI regime is crawling toward the hospitable environment of open economies. DFI was a mere trickle of less than a billion dollars in 1995.

A decisive turnaround resulted from the amendment of the Foreign Exchange Regulation Act (FERA) in 1993 which removed discrimination between firms with foreign equity and wholly-owned Indian companies. As a result, an established foreign investor can invest in a given activity on the same terms as an Indian investor. Again, profits can be remitted abroad without restrictions. However, foreign shareholding cannot exceed 49 percent. Foreigners cannot hold government securities, and can acquire private stock only in the illiquid secondary market.

Joint ventures (with equity participation of 49 percent) and consortia of foreign and domestic companies can participate in the basic and cellular telephone services in 20 regional "circles." DFI in electricity generation has been hampered by limited access to the final market for electricity and the shaky finances of State Electricity Boards with whom a foreign investor may have to collaborate. The RBI automatically approves foreign investment in mining with a maximum 50 percent equity participation. Such approval is readily granted also in drugs and pharmaceuticals with a maximum 51 percent foreign participation. A number of drugs have been exempted from price control. 
The post-1996-election government announced measures in June 1996 which eased conditions for external borrowing by Indian companies in infrastructure investment. These are aimed at raising $\$ 50$ billion from all sources in the next five years. As a result, financial and manufacturing companies can raise funds through global depository receipts or foreign-currency-denominated convertible bonds to finance infrastructure investment.

\section{The Institutional Infrastructure}

The financial sector reform, which began in 1992, is designed to regulate capital markets, strengthen commercial bank balance sheets, and deregulate the credit market.

The Securities and Exchange Board of India (SEBI) was established in 1992 with authority to regulate the capital market. Companies can raise capital without prior approval. There are no restrictions at present on bonus issues. Stocks and bonds can be traded on screen-based trading on the National Stock Exchange since June 1994. SEBI has substantial powers to regulate and impose penalties on participants for violations. Brokers are subject to strict guidelines announced by the RBI in March 1995 .

19 "nationalized" commercial banks received capital infusion of $\$ 3.3$ billion in 1994 from the government in exchange for strict financial performance. Some of them have subsequently borrowed from the equity market and become partially private. The improved balance sheets of the banking system prompted the government to deregulate lending rates.

Thus, interest rates on bank loans exceeding Rs. $200,000(\$ 6,400)$ were set free in October 1994. Interest rates on smaller, priority loans (for example, in the agricultural sector) and deposit rates continue to be fixed.

In sum, the government's ability to manage a monetary policy and public debt via open market operations is in place.

\section{Industrial Restructuring}

Little progress is evident in privatizing the massive public sector. The closure of sick units is embroiled in procedural wrangles and court battles. Retrenchment, retraining and retirement of the excess workforce in unviable units is at a standstill. Finally, viable public sector units can be privatized only up to 49 percent of their equity leaving them in charge of insiders and government bureaucrats. 


\section{NOTES}

1. I use the expressions "transition" (of the selected countries into the world economy) and "integration" (implying their increased trade and financial linkages with the global economy) interchangeably in this chapter because the objective on which the authors focus is globalization or its synonym, integration. I should also add that I use the term "liberalization" in the conventional sense, to imply market orientation.

2. From Plan to Market: World Development Report 1996 (hereafter the World Development

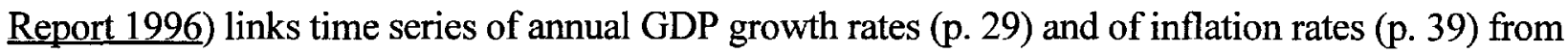
1989 to 1995 with liberalization indices and argues that rapid liberalization leads to quicker output turnaround and inflation control. However, it does not connect these indices with the growth rates of unemployment or of income disparity or of real wage decline over time thus ignoring the issue of trade-offs between a quick turnaround of output and a substantial rise in unemployment (or another misery indicator) that reforming policy makers must deal with in the short run. I address this issue at length later on.

3. As a result, the present volume differs from earlier contributions, among them Blanchard, Froot, and Sachs (1994); Bruno (1992); Bruno and Easterly (1995); CEPR (1992); Collins and Rodrik (1991); Gross and Steinherr (1995); Islam and Mandelbaum (1993); Kaminski, Wang, and Winters (1996); Lavigne (1995); Michalopoulos and Tarr (1994, 1996); Rodrik (1995); and Winters and Wang (1994). De Melo, Denizer, and Gelb (1995) and the World Development Report 1996, however, include some Asian countries along with several transition economies of Europe and the former Soviet Union in their analysis. 
4. So is East Germany, although it is included as an important country study. The reason is that its transition is uniquely special, insofar as it was inherently tied to unification with West Germany.

5. To deal with this problem, the World Development Report 1996 assigns weights of 0.3 each to liberalization of domestic and of external transactions, and of 0.4 to entry of new firms (p. 14). The problem, of course, is that there is no theoretically satisfactory way to arrive at such weights, and therefore a judgment-based approach, rather than the assignment of arbitrary fixed weights, may be more sensible. I have adopted this procedure in this essay, as in the case of Vietnam just discussed in the text, when I rank countries on their reform speed by weighing the five elements distinguished above. However, judging the five policy elements underlying the concept of reform speed in each case can be fairly tricky. For example, notions such as their being simultaneous run into the difficulty that they cannot be implemented simultaneously. For instance, liberalizing trade normally takes longer than freeing most prices; privatization takes even longer.

Despite these problems, the guidelines for characterizing speedy reform are more or less clear:the budget deficit, if inflationary, should be brought under control; prices, if administered and rigid, should be freed globally (except for the output of natural monopolies); the exchange rate should be unified and made convertible for current account transactions; market instruments should replace direct controls in credit allocation and foreign trade transactions; and these measures should be attempted in a policy package together and with dispatch. The six high-speed reformers in the text have come close to fulfilling these criteria.

Among the studies that discuss different aspects of reforms in transition economies, see Peck and Richardson (1991), and Lipton and Sachs (1990). 
6. To claim that shock therapy was "not tried" is to obscure its failure, since the political undoing of this strategy, when attempted, was precisely the reason why gradualists such as myself argued that it would fail.

7. If the political consensus for the necessary fiscal and monetary discipline is missing, the Sachs version of shock therapy, on its prescription that inflation should be slashed by fixing the exchange rate at the start of the stabilization process, is again unworkable. Here again, I believe that the Russian developments support my position, along with that of the IMF, which has had an eclectic view on which exchange rate policy will work best in which country when stabilization from high inflation is required.

8. Another example of the wrong sort of gradualism is the Hungarian New Economic Mechanism of 1968-88, described well by Blaho and Gal in this volume. By contrast, China's gradualism on dimensions such as privatization and import liberalization, which puts China surely into the "middle-speed" group of reformers, has nonetheless been compatible with huge success in growth rates, as studied systematically by John McMillan (1995a, 1995b) and Mcmillan and Naughton (1992), who therefore, with me, reject the view that high speed on every dimension of (say, the five) reforms is either a sufficient or a necessary condition for successful transition. Unfortunately, these issues are glossed over in the World Development Report 1996, which, in its uncritical enthusiasm for high-speed reforms, does not even include reference to our numerous writings.

9. Even though trade liberalization was announced by Vietnam, in reality it turned out to be slower than in the European countries; as a result, Vietnam gets a poor ranking (10 in Table 5) with respect to its trade policy regime in 1995. 
10. Other indicators are suggested and discussed, but data unavailability has prevented me from using them effectively.

11. Budget deficits for the European and post-Soviet states can be found in the European Bank for Reconstruction and Development (hereafter the EBRD; 1995, and 1996). Information for the Asian economies is available from World Bank and IMF reports.

12. In an apparent policy shift following Mexico's devaluation crisis, the IMF said that "during times of surges in inflows, a country might consider measures to influence the level and characteristics of capital inflows," such as taxes on short-term bank deposits and restrictions on borrowing from abroad, in order to avoid problems of exchange rate appreciation, a widening current account deficit, and accelerating money and credit growth. Details are in Folkerts-Landau and Ito (1995).

13. For a similar early observation on appreciating real exchange rates, see Halpern and Wyplosz (1995).

14. For a discussion of these concepts, see Desai (1994c, 1995a).

15. Even if the unemployment rate remains low, real wages may have declined. Also, income distribution may have worsened. In the analysis that follows, I adopt the unemployment rate as a proxy for these transition costs.

16. Note that the full convertibility of the Baltic currencies, despite continuing double-digit inflation rates, resulted from their adoption of arrangements resembling currency boards. Their aspirations for independent statehood and for swift integration into the European Union (EU), a hallmark of the Baltic leadership, crystallized from the start into their policy makers' decisions to junk the Soviet ruble, adopt fully convertible currencies, and re-create trade and investment links 
with the EU. For variations in their performance, see Chapter 5.

17. Later, I also rank countries according to their GDP growth and unemployment rates in 1995, and their record of inflation control (via three measures) for assessing the merits of speedy reform.

18. When I calculate the pairwise rank correlation coefficients between reform speed ranking (which I decide on the basis of the five policy variables and their implementation) and a policy outcome ranking (for example, the exchange rate regime), I avoid the problem of endogeneity by ranking all outcomes in 1995 , thus defining the transition policy package exogenously with a predetermined lag.

19. The distinctions among these arrangements and their policy implications are discussed in Williamson (1996).

20. For a succinct analysis of this issue and estimates of the loss of COMECON markets to East-Central European exporters, see Rodrik (1992).

21. All economies were also part of regional arrangements of one kind or another, as shown in the Appendix and in the country analyses.

22. The ranking remains virtually the same (except that Estonia ranks ahead of Hungary, with the rest ranked identically) when the ratios are averaged over the period. Hungary, however, should remain at the top because it has complete information for the five years and therefore its high performance is more reliable.

23. Unfortunately, as the reader will recall, the trade indicators such as trade participation and trade orientation in OECD markets could not be calculated for all countries, and therefore have to be discarded for the rest of the analysis in the text. 
24. It is not clear, however, that the Report clearly defines what "speed" means, whereas I have been at pains to emphasize its multidimensionality and hence the necessity for a proper, if judgment-based, approach to determining a country's quickness of reform in a study that seeks to draw conclusions about the efficacy of such speed. Nor does the Report adequately address the well-defined question of the relative merits of shock therapy and gradualism in the matter of stabilization itself, as I have already noted. 


\section{References}

Blanchard, O., K. Froot, and J. Sachs (eds.). 1994. Transition in Eastern Europe: A NBER Project Report. Chicago: University of Chicag Press.

Bruno, M. 1992. "Stabilization and Reform in Eastern Europe: A Preliminary Evaluation." IMF Staff Papers, 39, no. 4. Washington, D.C.: International Monetary Fund.

Bruno, M., and W. Easterly. 1995. Inflation Crises and Long-Run Growth. Policy Research Working Paper 1517. Washington, D.C.: World Bank.

Centre for Economic Policy Research (CEPR). 1992. Monitoring European Integration: The Impact of Eastern Europe. London: CEPR.

Collins, S., and D. Rodrik. 1991. Eastern Europe and the Soviet Union in the World Economy. Washington, D.C.: Institute for International Economics.

De Melo, M., C. Denizer, and A. Crelb. 1995. From Plan to Market: Patterns of Transition. Policy Research Working Paper. Washington, D.C.,: World Bank

Desai, P. 1994a. "No Megabucks and No Miracles: Russia and Western Aid." European Brief, pp.8-9 (April/May).

Desai, P. 1994b. "Gradualism -- What Makes the Reform Tick in Russia." The World Bank Transition, pp.15-16 (May/June).

Desai, P. 1994c. "Aftershock in Russia's Economy." Current History, pp. 320-323 (October).

Desai, P. 1995a. "Beyond Shock Therapy." Journal of Democracy, pp. 101-111 (April).

Desai, P. 1995b. "Russian Privatization: A Comparative Perspective." The Harriman Review, pp. 1-34 (August).

Desai, P. 1995c. "Will 1995 Stabilize Russia's Economy?" U.S. Relations with Russia, Ukraine and Eastern Europe. Washington, D.C.: Aspen Institute.

European Bank for Reconstruction and Development. 1995. Transition Report 1995, Investment and Enterprise Development: Economic Transition in Eastern Europe and the Former Soviet Union. London: EBRD.

European Bank for Reconstruction and Development. 1996. Transition Report Update. London: EBRD. 
Folkerts-Landau and Ito. 1995.

Gross, D., and A. Steinherr. 1995. Winds of Change: Economic Transition in Central and Eastern Europe. London: Longman.

Halpern, L., and C. Wyplosz. 1995. "Equilibrium Real Exchange Rates in Transition." Discussion Paper 1145. CEPR (April).

Islam, S., and M. Mandelbaum. 1993. Making Markets: Economic Transformation in Eastern Europe and the Post-Soviet States. New York: Council on Foreign Relations.

Kaminski, B., Z.K. Wang, and A. Winters. 1996. "Foreign 'Trade in the Transition: The International Environment and Domestic Policy." Studies of Economies in Transformation, 20. Washington, D.C.: World Bank.

Kokko, A., and M. Zejan. 1996. "Vietnam: At the Next Stage of Reforms." Stockholm School of Economics, April. (Mimeo).

Lavigne, M. 1995. The Economics of Transition from Socialist Economy to Market Economy. New York: St. Martin's Press.

Lipton, D., and J. Sachs. 1990. "Creating a Market Economy in Eastern Europe: The Case of Poland." In D. Lipton and J. Sachs (eds.), Brookings Papers on Economic Activity, 1:75147. Washington, D.C.: Brookings Institution.

McMillan, J. 1995a. "China's Nonconformist Reforms." In E. Lazear (ed.), Economic Transition in Eastern Europe and Russia: Realities of Reform. Stanford: Hoover Institution Press.

McMillan, J. 1995b. "Markets in Transition." Symposium address at the Seventh World Congress of the Econometric Society. Tokyo, August. (Mimeo).

McMillan, J., and B. Naughtin. 1992. "How to Reform a Planned Economy: Lessons from China." Oxford Review of Economic Policy, 8, no. 1, pp.130-143.

Michalopoulos, C., and D. Tarr. 1996. Trade Performance and Policy in the New Independent States. Washington, D.C.: World Bank.

Michalopoulos, C., and D. Tarr (eds.). 1994. "Trade in the New Independent States." Studies of Economies in Transformation. Washington, D.C.: World Bank.

Peck, M. J., and T. J. Richardson (eds.). 1991. What Is To Be Done? Proposals for the Soviet Transition to the Market. New Haven: Yale University Press. 
Portes, R. (ed.). 1993. Economic Transformation in Central Europe. London: CEPR.

Rodrik, D. 1995. "The Dynamics of Political Support for Reform in Economies in Transition." Journal of the Japanese and International Economies, vol. 9, no. 4, pp.403-425 (December).

Rodrik, D. 1992. Making Sense of the Soviet Trade Shock in Eastern Europe: A Framework and Some Estimates. NBER Working Paper (June).

Sapir, A. 1994. "The Europe Agreements: Implications for Trade Laws and Institutions. Lessons from Hungary." Discussion Paper 1024. CEPR (September).

Williamson, J. 1995. "How to Manage Exchange Rates: Lessons from Israel, Chile and Colombia." Institute for International Economics (October).

Winters, L. A., and Z. K. Wang. 1994. Eastern Europe's International Trade. Manchester, U.K.: Manchester University Press.

World Bank. 1996. From Plan to Market: World Development Report 1996. Washington, D.C.: World Bank. 


\title{
1996-1997 Discussion Paper Series
}

\author{
Department of Economics \\ Columbia University \\ 1022 International Affairs Bldg. \\ 420 West 118 th Street \\ New York, N.Y., 10027
}

The following papers are published in the 1996-97 Columbia University Discussion Paper series which runs from early November to October 31 of the following year (Academic Year).

Website: $\quad$ http://www.columbia.edu/dlc/wp/econ/index.html.

You may download any papers found on this site.

Eor Ordering Hardcopies:

Domestic orders for discussion papers are available for purchase at the cost of $\$ 8.00$ (U.S.) Per paper and $\$ 140.00$ (US) for the series.

Foreign orders cost $\$ 10.00$ (US) per paper and $\$ 185.00$ for the series.

To order discussion papers, please write to the Discussion Paper Coordinator at the above address along with a check for the appropriate amount, made payable to Department of Economics, Columbia University. Please be sure to include the series number of the requested paper when you place an order. 


\section{6-97 Discussion Paper Series}

9697-01 Fertility Behavior Under Income Uncertainty

by: P. Ranjan

9697-02 Trade Restrictions, imperfect Competition and National Welfare with Foreign Capital Inflows

9697-03 Restructuring an Industry during Transition: a Two-Priced Model

by: P. Ranjan

by: R. Ericson

9697-04 A Conformity Test for Cointegration

by: P. Dhrymes

9697-05 Low-Wage Employment Subsidies in a Labor-Turnover Model of the 'Natural Rate' (November 1996)

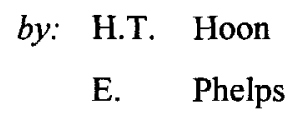

9697-06 The Knowledge Revolution

by: G. Chichilnisky

9697-07 The Role of Absolute Continuity in "Merging Opinions" and "Rational Learning"

by: R. Miller

C.W. Sanchirico

9697-08 The Soviet Bloc and the Soviet Union: Why did they fall apart?

by: P. Desai

9697-09 Regionalism and Multilateral Tariff Cooperation

by: K. Bagwell

R. Staiger

9697-10 Supplier Relations and the Market Context: A theory of handshakes

by: J. McLaren

9697-11 Vertical Foreclosure with the Choice of Input Specifications

by: J.P. Choi

S. Yi

9697-12 Equilibrium Vertical Foreclosure with Investment

by: J.P. Choi

S. $\mathrm{Yi}$

9697-13 Going Global: Transition from Plan to Market in the World Economy

by: P. Desai 